\title{
WestVirginiaUniversity
}

THE RESEARCH REPOSITORY @ WVU

Graduate Theses, Dissertations, and Problem Reports

2008

\section{Three essays on credit constraints and capital structure}

Christine M. Harrington

West Virginia University

Follow this and additional works at: https://researchrepository.wvu.edu/etd

\section{Recommended Citation}

Harrington, Christine M., "Three essays on credit constraints and capital structure" (2008). Graduate Theses, Dissertations, and Problem Reports. 4378.

https://researchrepository.wvu.edu/etd/4378

This Dissertation is protected by copyright and/or related rights. It has been brought to you by the The Research Repository @ WVU with permission from the rights-holder(s). You are free to use this Dissertation in any way that is permitted by the copyright and related rights legislation that applies to your use. For other uses you must obtain permission from the rights-holder(s) directly, unless additional rights are indicated by a Creative Commons license in the record and/ or on the work itself. This Dissertation has been accepted for inclusion in WVU Graduate Theses, Dissertations, and Problem Reports collection by an authorized administrator of The Research Repository @ WVU.

For more information, please contact researchrepository@mail.wvu.edu. 


\title{
THREE ESSAYS ON CREDIT CONSTRAINTS AND CAPITAL STRUCTURE
}

\author{
Christine M. Harrington \\ Dissertation submitted to the College of Business and Economics \\ at West Virginia University \\ in partial fulfillment of the requirements \\ for the degree of \\ Doctor of Philosophy \\ in \\ Economics
}
Approved by
Ronald J. Balvers, Ph.D., Chair
Ashok B. Abbott, Ph.D.
Arabinda Basistha, Ph.D.
Stratford M. Douglas, Ph.D.
Alexei V. Egorov, Ph.D.
Department of Economics
Morgantown, West Virginia
2008

Keywords: Capital Structure, Financing Constraints, Pecking Order Model,

Product Market Competition

Copyright 2008 Christine M. Harrington 


\section{ABSTRACT \\ THREE ESSAYS ON CREDIT CONSTRAINTS AND CAPITAL STRUCTURE}

\section{Christine M. Harrington}

The first essay, "Debt Capacity Constraints, Information, and the Pecking Order Model of Capital Structure", investigates why the pecking order model does not appear to describe the financing choices of small and growth firms. The pecking order model predicts debt issues only when a firm has the capacity to absorb new debt and when firm value is relatively predictable. By explicitly controlling for asymmetric information about firm risk, empirical tests support the predictions of the pecking order model for small and growth firms.

The second essay, "The Sensitivity of Investment to Internal Funds When the Costs of External Funds Differ", asks whether the observed investment-cash flow sensitivity of financially constrained firms can be explained by relatively high security issue costs. Security issue costs are indicative of credit constraints. The empirical tests suggest that only cash is relatively more important to investment spending for high issue cost firms, but not because of the need for cash to fund planned investment. Cash serves as an indicator of growth opportunities not captured by empirical approximations of Tobin's Q. Further tests demonstrate that commonly used methods to identify financially constrained firms mimic relatively high security issue costs.

The third essay, "The Effect of Competitive Structure on the Relationship between Leverage and Profitability", attempts to explain why firms in concentrated industries have different responses of leverage ratios to current profitability. The leverage-profitability relationship is important to distinguishing between the pecking order and trade-off theories of capital structure. The essay examines whether the speed of reversion in profitability affects the leverage-profitability relationship. When U.S. Census data are used to measure industry concentration, the empirical results support the prediction that differences in the leverage-profitability relationship between competitive and concentrated industries is related to differences in the speed of reversion in profitability. 


\section{DEDICATION}

To my mother,

Marlene D. Harrington

and my father,

Raymond F. Harrington,

who would have been so proud 


\section{ACKNOWLEDGMENTS}

I thank the members of my committee, Ashok Abbott, Arabinda Basistha, Strat Douglas, Alexei Egorov, and especially Ron Balvers, the Chair. Ron Balvers is the best role model that a graduate student could have, and I am grateful for his generosity with his time, insights, and numerous readings of my papers. Thank you, Ron, for giving me the opportunity to study at WVU, and for sticking with me during this long process. I also thank my mother, Marlene Harrington, for always being supportive of me, no matter what I pursued or how long I took to graduate. Thank you to Lillian Kamal for being my WVU information lifeline and a good friend. Saving the best for last, thank you to Walter Smith, my spouse, my friend, for giving up so much while I completed my degree. I owe you many for taking care of Jimi, Lester, Shado, Eunice, LittleKitty, Junior, and everything else while I worked peacefully in Morgantown. 


\section{TABLE OF CONTENTS}

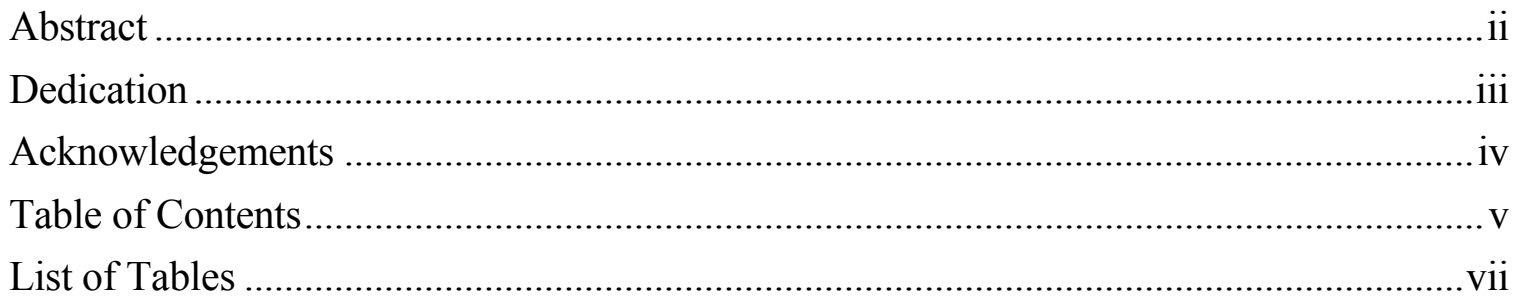

Chapter 1: Debt Capacity Constraints, Information, and the Pecking Order Model

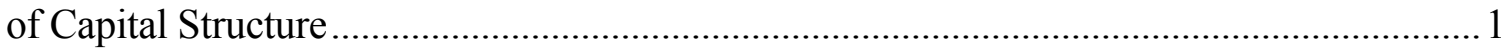

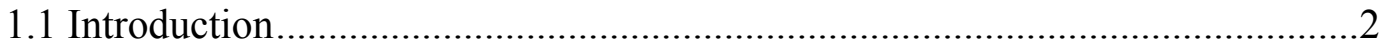

1.2 Prior Tests of the Pecking Order Model .......................................................

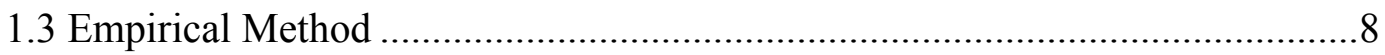

1.3.1 Classifying Firms by Size and Growth ........................................... 8

1.3.2 Definition of the Financing Deficit..................................................

1.3.3 Shyam-Sunder and Myers Regression ............................................10

1.3.4 Debt Capacity Considerations.......................................................11

1.3.5 Asymmetric Information about Firm Risk....................................13

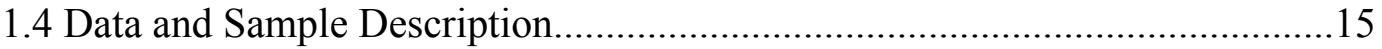

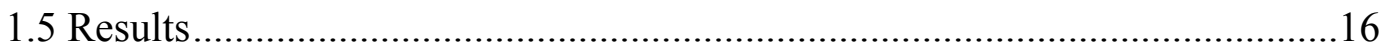

1.5.1 Tests of the Basic Pecking Order Model …………......................17

1.5.2 Controlling for Debt Capacity Constraints .....................................18

1.5.3 Controlling for the Nature of Asymmetric Information .................18

1.6 Robustness of Results to Alternative Variable Definitions .............................20

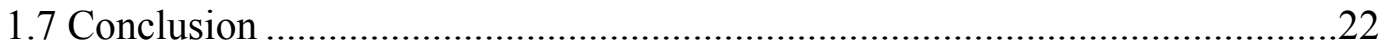

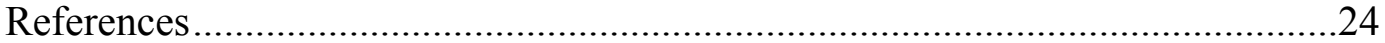

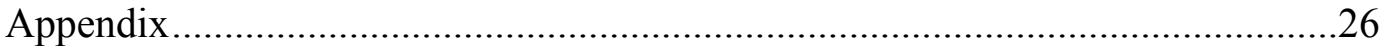

Chapter 2: The Sensitivity of Investment to Internal Funds When the Costs of External

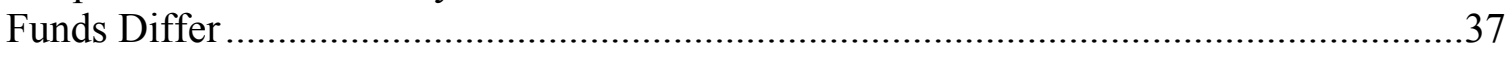

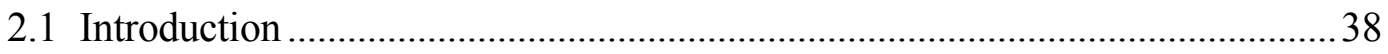

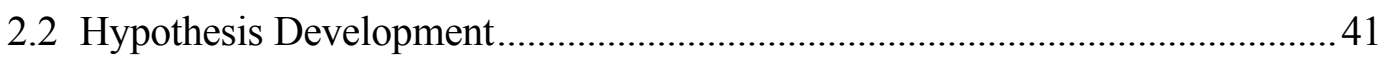

2.2.1 Cost of External Funds..................................................................... 43

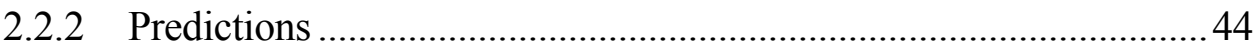




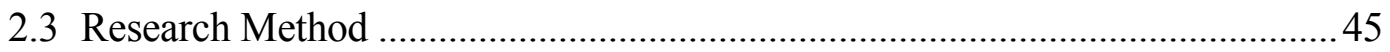

2.3.1 Measuring Security Issue Cost ...................................................... 45

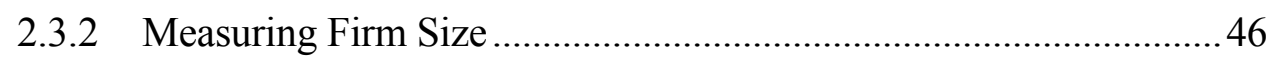

2.3.3 Measuring the Investment-Internal Funds Response ........................46

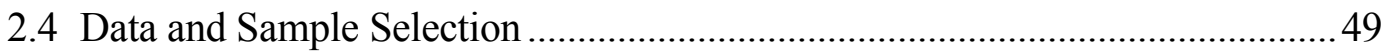

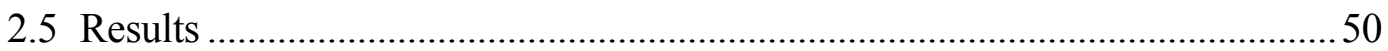

2.5.1 Cash as a Source of Liquidity or an Indicator of Investment

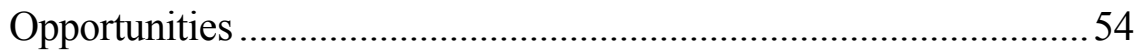

2.6 Do Methods of Identifying Financially Constrained Firms Mimic High Capital

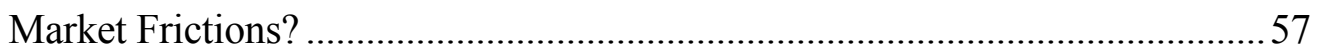

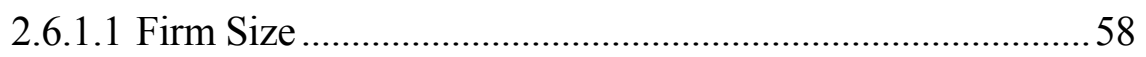

2.6.1.2 Dividend Payout ................................................................... 58

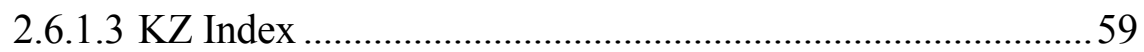

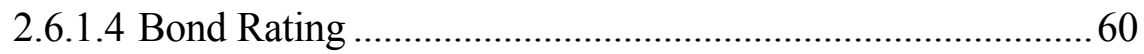

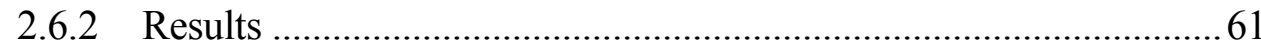

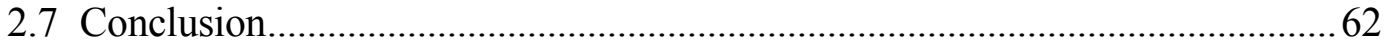

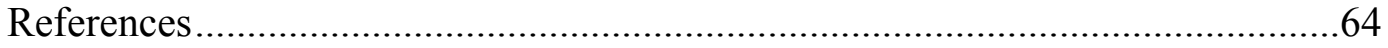

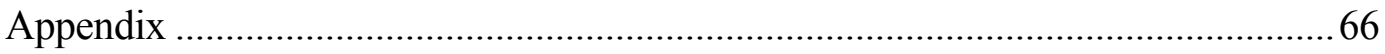

Chapter 3: The Effect of Competitive Structure on the Relationship between

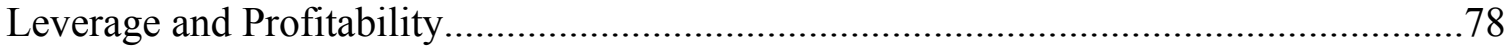

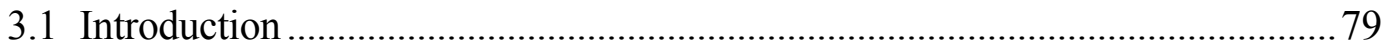

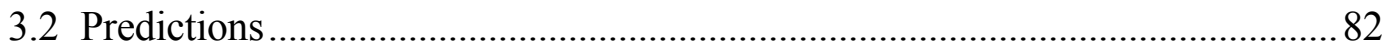

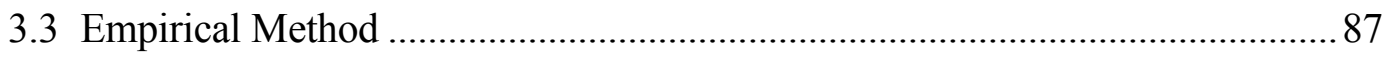

3.3.1 Estimating Industry Concentration .................................................. 88

3.3.2 Estimating the Components of Profitability ...................................... 89

3.3.3 Estimating the Response of Leverage to Profitability ...................... 90

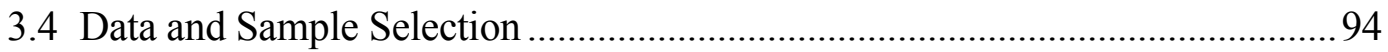

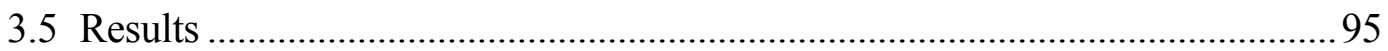

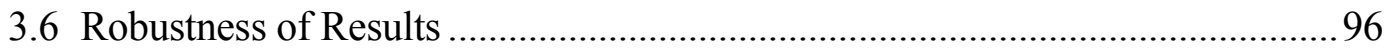

3.6.1 Sensitivity to Alternative Estimates of Reversion in Profitability ...97

3.6.2 Sensitivity to Alternative Definitions of Leverage.......................... 102

3.6.3 Sensitivity to the Definition of Industry Concentration ................... 103

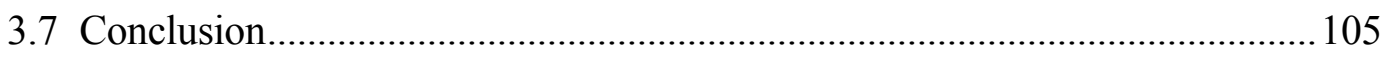

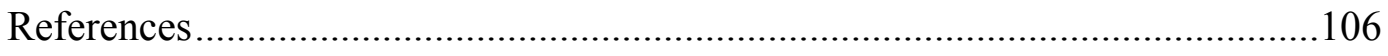




\section{LIST OF TABLES}

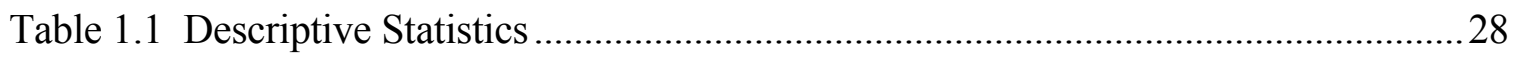

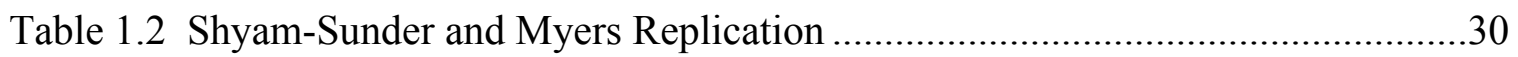

Table 1.3 Debt Issues Controlling for Debt Capacity ..................................................

Table 1.4 Debt Issues Controlling for Debt Capacity and Risk.....................................32

Table 1.5 Debt Issues Controlling for Debt Capacity and Risk, NDCC Firms Only .......33

Table 1.6 Robustness to Alternative Definition of Firm Size, NDCC Firms Only ..........34

Table 1.7 Robustness to Alternative Definition of Firm Risk, NDCC Firms Only..........35

Table 1.8 Robustness to Alternative Definition of Debt Capacity, NDCC Firms Only...36

Table 2.1 Descriptive Statistics for Size Sorted Samples.................................................67

Table 2.2 Investment Response to Cash Flow and Cash for Size-Sorted Samples .........69

Table 2.3 Within-Group Comparisons of Coefficient Estimates for Cash Flow ..............70

Table 2.4 Within-Group Comparisons of Coefficient Estimates for Cash .....................71

Table 2.5 Between-Group Comparisons of Coefficient Estimates .................................72

Table 2.6 Investment Response to Cash Flow, Issue Year Cash, and Post-issue Year

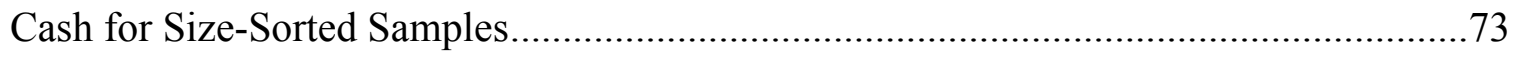

Table 2.7 Robustness to Alternative Proxies for the Constraint Factor, Between-Group Comparisons of Coefficient Estimates for Cash Flow.................................................... 74

Table 2.8 Robustness to Alternative Proxies for the Constraint Factor, Between-Group Comparisons of Coefficient Estimates for Cash ................................................... 75

Table 2.9 Investment Response to Cash Flow, Issue Year Cash, and Post-issue Year

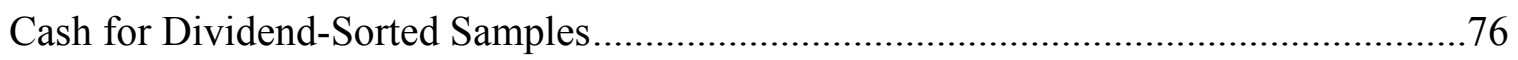

Table 2.10 Investment Response to Cash Flow, Issue Year Cash, and Post-issue Year

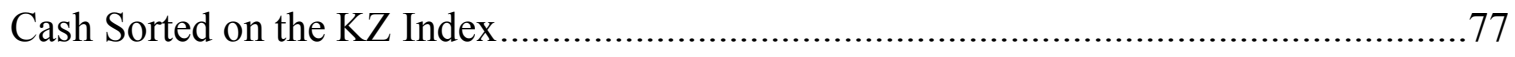

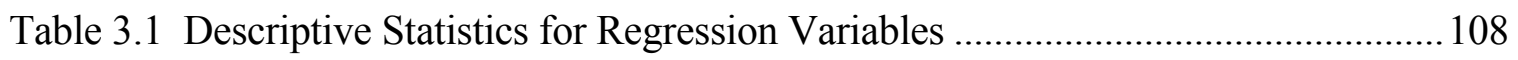

Table 3.2 Pearson Correlation Coefficients for Regression Variables ..........................109

Table 3.3 Regression Results for Book Leverage ...................................................110

Table 3.4 Two-way Interactions: Book Leverage ................................................111

Table 3.5 Robustness to Fama and French (2002) Method of Estimating Reversion in Profitability: Regression Results....................................................................112 
Table 3.6 Robustness to Fama and French (2002) Method of Estimating Reversion in

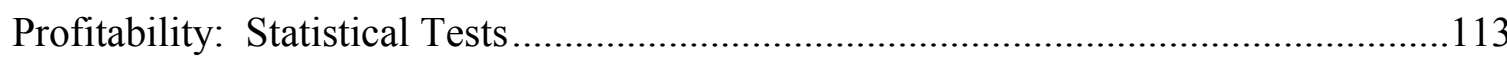

Table 3.7 Robustness to Balvers, Wu, and Gilliland (2000) Method of Estimating

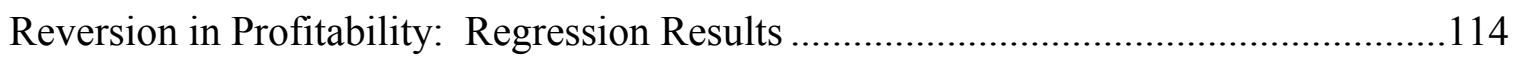

Table 3.8 Robustness to Balvers, Wu, and Gilliland (2000) Method of Estimating

Reversion in Profitability: Statistical Tests............................................................115

Table 3.9 Robustness to AR (1) Method of Estimating Reversion in Profitability:

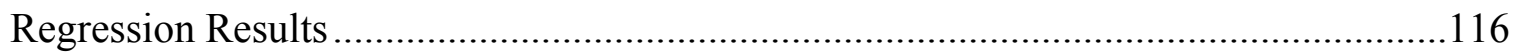

Table 3.10 Robustness to AR (1) Method of Estimating Reversion in Profitability:

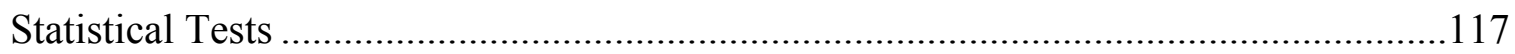

Table 3.11 Robustness to Alternative Leverage Definitions: Regression Results.........118

Table 3.12 Robustness to Alternative Leverage Definitions: Statistical Tests ..............119

Table 3.13 Robustness to Industry Concentration Definition: Regression Results for

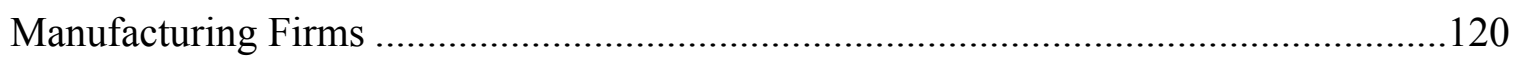

Table 3.14 Robustness to Industry Concentration Definition: Statistical Tests for

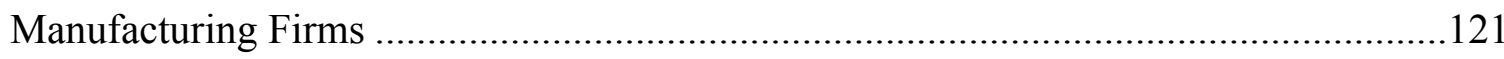




\title{
Chapter 1
}

\section{Debt Capacity Constraints, Information, and the Pecking Order Model of Capital Structure}

\begin{abstract}
Prior empirical results suggest that the pecking order model better explains the financing behavior of large public firms compared to small and growth firms. This paper finds that the lack of support for the pecking order model in samples of small and growth firms is driven in part by differences in asymmetric information about firm risk. The results from explicitly controlling for debt capacity constraints and the influence of asymmetric information about firm risk suggest that risk is highly relevant to small, growth firms. Small and high growth firms with relatively low asymmetric information about firm risk and that are not concerned with debt capacity constraints issue an equivalent proportion of debt as large, mature firms when filling the financing deficit. The results of this study indicate that high-risk small-high growth firms fund investment primarily with equity, an observation that is consistent with the pecking order model of Myers and Majluf (1984).
\end{abstract}




\subsection{Introduction}

The general applicability of the pecking order model of Myers (1984) and Myers and Majluf (1984) has been challenged by the observation that small and growth firms primarily issue equity, counter to the model's standard prediction of debt issues when external financing is needed (Helwege and Liang, 1996; Fama and French, 2002; Frank and Goyal, 2003) ${ }^{1}$. Recent studies suggest that the standard result of the pecking order model is conditional on firm characteristics. Specifically, debt financing arises as a special case when firms have sufficient debt capacity (Lemmon and Zender, 2002; Agca and Mozumdar, 2003), are mature in their life cycle (Bulan and Yan, 2006), or are least susceptible to problems with risk assessment (Halov and Heider, 2005). Rather than dooming the pecking order model to failure based on the observation that young firms are predominantly equity issuers, the model does predict equity issues conditional on the inability to assess firm risk.

The pecking order model in Myers (1984) and Myers and Majluf (1984) is based on asymmetric information between market participants and firm managers, wherein market participants discount the value of securities as compensation for the possibility of purchasing a "lemon" (Akerlof, 1970). The standard financing hierarchy predicted by the pecking order model (firms will first use internal funds, then riskless debt, risky debt, and equity as a last resort) results from progressively relaxing assumptions of the model. For financing investment, internal funds are preferred to external resources given that the firm has sufficient retained earnings. Relaxing this assumption, the firm with sufficient debt capacity and a relatively predictable payoff from the use of assets will issue debt. In

\footnotetext{
${ }^{1}$ Carpenter and Petersen (2002) find that high-tech firms that obtain external financing do so mainly with secured debt.
} 
this case, asymmetric information between investors and managers is about the payoff of the investment (assuming that investors know the distribution of possible payoffs, if not the payoff itself). Without debt capacity, the firm issues equity ${ }^{2}$. However, with debt capacity, but without a relatively predictable outcome from the use of assets, or when there is greater asymmetric information about the variance of possible payoffs, the model predicts equity issues to finance investment. As stated in Myers and Majluf, this is the case where asymmetric information about firm risk dominates that of firm value. The security issue predictions of the pecking order model are summarized below and clearly indicate that debt issues are a special case of the model when asymmetric information about risk and debt capacity constraints are not overriding concerns:

\begin{tabular}{l|cc} 
& $\begin{array}{c}\text { No debt capacity } \\
\text { constraint }\end{array}$ & $\begin{array}{c}\text { Debt capacity } \\
\text { constraint }\end{array}$ \\
\hline $\begin{array}{l}\text { Asymmetric information about } \\
\text { value dominates asymmetric } \\
\text { information about risk }\end{array}$ & Debt & Equity \\
$\begin{array}{l}\text { Asymmetric information about } \\
\text { risk dominates asymmetric } \\
\text { information about value }\end{array}$ & Equity & Equity
\end{tabular}

This study tests whether asymmetric information about risk is relevant to the debtequity choice as predicted in Myers and Majluf (1984). The central hypothesis for empirical tests is that firms engaging in inherently more risky projects are those for which investors are likely to have the greatest difficulty assessing firm risk. Firms with

\footnotetext{
${ }^{2}$ Myers (1984) argues that firms requiring high levels of external financing are debt capacity constrained, regardless of existing leverage.
} 
relatively greater asymmetric information about firm risk are expected to issue equity in the context of the pecking order model even when debt capacity is not a concern. This result is expected to emerge particularly for small and growth firms, subsamples that may be most susceptible to problems with assessing both firm risk and value.

Firms that engage in inherently risky projects are identified as those with relatively high research and development expenditures. R\&D intensity has previously been used as an explanatory variable for debt issues (e.g., Bhagat and Welch, 1995; Bradley, Jarrell, and Kim, 1984) for much the same reason that it is used herein- - to identify firms with inherently risky projects. However, previous studies do not formally explain why R\&D intensity should matter to debt issuance, whereas Myers and Majluf provide a foundation for the use of R\&D intensity to approximate asymmetric information about firm risk.

The research question is similar to that in Halov and Heider (2005), who use market-based measures to approximate perceptions of firm risk. The investigation also extends the work of Lemmon and Zender (2002) and Agca and Mozumdar (2003) by considering the role of debt capacity constraints in the external financing decision jointly with the nature of asymmetric information, relating these firm characteristics to security issues predicted in Myers and Majluf (1984).

As a benchmark case, the main empirical test in Shyam-Sunder and Myers (1999) is replicated for samples defined by size and growth. The regression results are similar to those in Frank and Goyal (2003) in all subsamples except for low-growth, small firms. This subsample of firms primarily issues debt to fill the financing deficit. The results from explicitly controlling for debt capacity constraints show that small, high growth 
firms without debt capacity constraints issue significantly more debt than small, high growth firms with debt capacity constraints, supporting the conclusions in Lemmon and Zender (2002). Asymmetric information about firm risk is highly relevant to small, growth firms. Small, high growth firms with relatively low asymmetric information about firm risk and without debt capacity constraints issue an equivalent proportion of debt as large, mature firms when filling the financing deficit. This result is counter to the conclusion of Frank and Goyal (2003) about small and growth firms. The results of this study indicate that high-risk small-high growth firms fund investment primarily with equity, an observation that is consistent with the pecking order model of Myers and Majluf(1984).

The paper continues as follows. Section 2 describes prior empirical tests of the pecking order model. Section 3 sets up the empirical method used to test the predictions of the pecking order model. The data and sample selection are described in Section 4. The results from testing the propositions of the pecking order model are presented and discussed in Section 5, and the robustness of the results is examined in Section 6. Section 7 concludes.

\subsection{Prior tests of the pecking order model}

Shyam-Sunder and Myers (1999) test the prediction that firms prefer to issue debt to fill a financing using the following regression function:

$$
\Delta \mathrm{DEBT}_{\mathrm{jt}}=\mathrm{b}_{0}+\mathrm{b}_{1} \mathrm{DEF}_{\mathrm{jt}}+\mathrm{e}_{\mathrm{jt}}
$$


$\triangle \mathrm{DEBT}_{\mathrm{jt}}$ is the net debt issue of firm $\mathrm{j}$ in period $\mathrm{t}$ and $\mathrm{DEF}_{\mathrm{jt}}$ is the financing deficit, or the difference between cash flows and investment of firm $\mathrm{j}$ in period $\mathrm{t}$. The pecking order model predicts that $b_{0}=0$ and $b_{1}=1$. Shyam-Sunder and Myers conduct their empirical tests with a sample of 157 firms with a 19-year continuous history in Compustat.

Because only large and mature firms are considered, the sampling procedure incorporates the assumptions that firms have sufficient debt capacity. The survival requirement is also likely to control for the predictability of the distribution of firm value. Shyam-Sunder and Myers find that the estimated intercept is statistically equal to zero, and that the coefficient estimate for DEF is around 0.7 , and based on this and additional tests, conclude that the pecking order is a good first-order approximation of the financing choices of their sample firms.

Chirinko and Singha (2000) question the ability of the tests in Shyam-Sunder and Myers (1999) to provide support for the pecking order prediction that firms follow a financing hierarchy. Chirinko and Singha propose that while the Shyam-Sunder/Myers test fails to generate an $\mathrm{R}^{2}$ of $100 \%$, the empirical results are consistent with a weakerform hypothesis that firms will first exhaust internal funds, and then issue debt up to debt capacity, and as a last resort, issue equity to generate the remaining cash needed for investment. However, the results are also consistent with the static trade-off prediction that firms issue a mix of debt and equity to maintain optimal capital structure (Chirinko and Singha, 2000).

Frank and Goyal (2003) reexamine the results in Shyam-Sunder and Myers (1999) for a broader sample that includes small and high growth firm. Sorting firms by asset size and the market-to-book ratio as a proxy for growth prospects, Frank and Goyal 
estimate eq. (1) and find general support for the Shyam-Sunder and Myers results for the large and low growth samples. However, Frank and Goyal argue that the pecking order model does not adequately describe the financing choices of small and growth firms, which are observed to be net equity issuers.

Lemmon and Zender (2002) and Agca and Mozumdar (2003) suggest that the small and growth firm results in Frank and Goyal (2003) are linked to concerns over debt capacity constraints. Lemmon and Zender show that younger, high growth firms tend to have the highest debt capacity constraints, and firms with these characteristics tend to issue equity to fill the financing deficit, as predicted in Myers (1984) and Myers and Majluf (1984). Agca and Mozumdar also control for debt capacity constraints, and generate results similar to those in Shyam-Sunder and Myers (1999) for firms that are relatively unconstrained by debt capacity.

Similar to Lemmon and Zender (2002) and Agca and Mozumdar (2003), this study also attempts to explain the lack of support for the pecking order model in small and growth firm samples found in Frank and Goyal (2003) by considering the role of debt capacity constraints in the debt-equity choice. Unlike prior studies, this study also considers the role of the nature of asymmetric information in the debt-equity choice. If small, growth firms are inherently more susceptible to asymmetric information about firm risk due to a relatively limited public track record, then even if debt capacity constraints are not a concern, these firms may issue equity as predicted by the pecking order model. On the other hand, if small, growth firms undertake projects with reasonably predictable outcomes, then asymmetric information about the value of the investment may override 
asymmetric information about risk. In this case, small, growth firms are predicted to issue debt when debt capacity is not reached.

\subsection{Empirical method}

The investigation of whether asymmetric information about firm risk influences the debt-equity choice of small, growth firms is conducted in several steps to net out the firm years for which asymmetric information about firm risk may dominate asymmetric information about firm value. As in Frank and Goyal (2003), firm years are first classified by size and growth and the Shyam-Sunder and Myers (1999) regression is replicated for four cohorts of firm years, small-low growth, small-high growth, large-low growth, and large-high growth. This replication provides a benchmark set of results for the influence of a financing deficit on debt issues. Controls for debt capacity constraints are introduced into the Shyam-Sunder and Myers test to produce a second set of benchmark results. The pecking order model predicts debt issues when two conditions are satisfied: sufficient debt capacity and symmetric information about the distribution of future firm value. Equity issues are predicted in all other cases. Therefore, firm years in which debt capacity constraints are not a concern are the candidate firm years for testing whether asymmetric information about the variance of firm risk is important to the security issue choice of firms with financing deficits.

\subsubsection{Classifying firms by size and growth}

Firms are classified by size based on the distribution of real beginning-period total assets. Similar to Frank and Goyal (2003), firm years in the third of the distribution 
containing the lowest values of the total assets distribution are labeled as "small", and "large" firm years are defined as those observations in the third with the highest values of total assets. Using an independent sort, firm years are classified by growth based on the distribution of the beginning-period market-to-book assets ratio. Firm years in the third of the distribution containing the highest market-to-book values of assets are labeled as "high growth", and firm years in the lowest third of the market-to-book distribution are referred to as "low growth". To control for overlap between size and growth, a "four corner cut" is used to classify firms as small-low growth, small-high growth, large-low growth, and large-high growth. For example, the small-high growth subsample contains firm years that are classified as both small and high growth. Because the extremes of the distributions of size and growth measures are central to explaining the lack of support for the pecking order model in Frank and Goyal, firm years that do not fall into one of the four above categories are omitted from the analysis.

\subsubsection{Definition of the financing deficit}

The financing deficit is defined as in Frank and Goyal (2003) as the sum of ordinary dividends, change in working capital, and investment spending less internal cash flows, or

$$
\mathrm{DEF}_{\mathrm{t}}=\mathrm{DIV}_{\mathrm{t}}+\Delta \mathrm{WCAP}_{\mathrm{t}}+\mathrm{INVEST}_{\mathrm{t}}-\mathrm{CASHFLOW}_{\mathrm{t}}=\Delta \mathrm{DEBT}_{\mathrm{t}}+\Delta \mathrm{EQ}_{\mathrm{t}}
$$

The variables that define DEF are constructed as follows:

DIV $_{\mathrm{t}} \quad$ Ordinary cash dividends in year $\mathrm{t}$

$\Delta \mathrm{WCAP}_{\mathrm{t}} \quad$ Change in working capital in year $\mathrm{t}, \Delta \mathrm{WCAP}_{\mathrm{t}}=$ change in operating working 
capital + change in cash and equivalents + change in current debt

INVEST $_{\mathrm{t}} \quad$ Net investment in year $\mathrm{t}, \mathrm{INVEST}_{\mathrm{t}}=$ capital expenditures + increase in investments + acquisitions + other use of funds - sale of PPE - sale of investments

CASHFLOW $_{\mathrm{t}}$ Cash flow after interest and taxes, CASHFLOW $\mathrm{t}_{\mathrm{t}}=$ income before extraordinary items + depreciation and amortization + extraordinary items and discontinued operations + deferred taxes + equity in net loss + other funds from operations + gain (loss) from sales of PPE and other investments

$\triangle \mathrm{DEBT}_{\mathrm{t}} \quad$ Net debt issued in year $\mathrm{t}, \Delta \mathrm{DEBT}_{\mathrm{t}}=$ long-term debt issuance - long-term debt reductions

$\Delta \mathrm{EQ}_{\mathrm{t}} \quad$ Net equity issued in year $\mathrm{t}, \Delta \mathrm{EQ}_{\mathrm{t}}=$ sale of common and preferred stock - stock repurchases

Period $t$ refers to the end of the fiscal period.

\subsubsection{Shyam-Sunder and Myers regression}

Frank and Goyal (2003) use the regression function in Shyam-Sunder and Myers (1999) to test the ability of the financing deficit to explain net debt issues for small and growth firms. Although additional research demonstrates the importance of controlling for debt capacity constraints, the Shyam-Sunder and Myers regression serves as a benchmark for comparing the results that consider the influence of debt capacity constraints and the nature of the asymmetric information. According to the pecking order model, if asymmetric information about firm value dominates asymmetric information about firm risk and if debt capacity constraints are not a concern, then absent sufficient internal funds, firms choose to finance investment with debt issues, or,

$$
\mathrm{DEF}_{\mathrm{t}}=\Delta \mathrm{DEBT}_{\mathrm{t}}
$$

Shyam-Sunder and Myers empirically investigate this proposition with the following regression function: 


$$
\Delta \mathrm{DEBT}_{\mathrm{jt}}=\mathrm{b}_{0}+\mathrm{b}_{1} \mathrm{DEF}_{\mathrm{jt}}+\mathrm{e}_{\mathrm{jt}}
$$

As discussed earlier, Chirinko and Singha (2000) note that eq. (1) is a strong-form hypothesis with an expected $\mathrm{R}^{2}$ of $100 \%$. Chirinko and Singha also suggest that at some level of debt issues, debt capacity constraints may be binding, and firms primarily filling the financing deficit with debt may also issue equity to generate the remaining cash needed for investment. The implication is that a weak-form hypothesis is more likely to be observed.

\subsubsection{Debt capacity considerations}

As in Lemmon and Zender (2002), debt capacity constraints are approximated by a firm's expected future financing deficit over a 5-year period and its initial leverage relative to the industry median at the beginning of the 5-year period. To create the expected future financing deficit, firm years are grouped into 5-year non-overlapping intervals, and then the financing deficit is averaged within each 5-year period. A firm must have at least 3 observations of the financing deficit to be included in an interval.

For each 5-year interval, firms are sorted into three groups based on the average financing deficit: low, moderate, and high future external financing needs. A firm's leverage position in the first year it enters an interval is measured relative to the industry median at the beginning of the interval. Leverage is defined as the ratio of long-term debt to total assets. The industry median debt-to-assets ratio is located by 2-digit SIC code. Firms are independently sorted into two groups based on the leverage position observed at the beginning of each interval: low and high initial leverage (relative to the 
industry median). Firms with high future financing needs are considered as constrained by debt capacity regardless of the initial leverage position (DCC). Firms with moderate expected future financing needs and low initial leverage are classified as not concerned over debt capacity constraints (NDCC).

Absent any asymmetric information about firm risk, the pecking order model predicts that NDCC firms issue debt to fill the financing deficit. To test this prediction controlling for debt capacity constraints, the financing deficit (DEF) and the regression intercept are interacted with indicators for NDCC firm years (the indicator equals one if a firm year is classified as NDCC, 0 otherwise). The following regression function is used to test the explanatory power of the financing deficit under conditions of debt capacity constraints and otherwise:

$$
\Delta D B_{j} T_{j t}=a_{N D C C}+a_{D C C}+b_{1} D E E F_{j t}^{N D C C}+b_{2} D E F_{j t}^{D C C}+e_{j t}
$$

In the above equation, $\mathrm{a}_{\mathrm{NDCC}}$ corresponds to the intercept term for the NDCC firm years, and $\mathrm{a}_{\mathrm{DCC}}$ to the intercept term for firm years concerned over debt capacity constraints (DCC). $\mathrm{DEF}^{\mathrm{NDCC}}$ represents the financing deficit interacted with the indicator for NDCC firm years, and $\mathrm{DEF}^{\mathrm{DCC}}$ is the financing deficit interacted with the indicator for DCC firm years. Absent any asymmetric information about firm risk and concerns over debt capacity constraints, the pecking order theory predicts that $a_{\mathrm{NDCC}}=0$ and $\mathrm{b}_{1}=1$ (strong-form hypothesis). For firm years in which debt capacity is a concern, the pecking order model predicts that $a_{D C C}=0$ and $b_{2}<1$. If the weak-form hypothesis holds, then the 
coefficient estimate for $b_{1}$ is expected to be statistically and economically larger than that for $b_{2}$.

\subsubsection{Asymmetric information about firm risk}

Prior studies suggest that firms that are relatively intensive in research and development activities tend to use less debt in their capital structure (for example, Bhagat and Welch, 1995). Myers and Majluf (1984) and Hall (2002) offer possible explanations for this observation. First is the risk of competition that may result from fully disclosing the details of an innovation project. Second, firms that are relatively intensive in $R \& D$ face the joint risk of turnover in employees associated with the project and an uncertain payoff of the project itself. Hall suggests that the need to retain employees involved in a project with an uncertain payoff may cause the firm to act as if it faces high adjustment costs to the prospect of human capital loss. Hall explains that a large fraction of R\&D expense is in salaries and wages, and the innovation project does not generate the required cash flow. Given the disclosure and payoff risks, firms that are relatively R\&D intensive may have a more severe form of information asymmetry about firm risk that may dominate asymmetric information about firm value, resulting in less debt offerings compared to firms with less (or zero) R\&D intensity. Information asymmetry about firm risk arising from the relatively risky use of assets in pursuit of product development is expected to be compounded by a relatively limited existence as a public firm and/or aggressive growth strategies.

As a proxy for asymmetric information about firm risk, the influence of $R \& D$ intensity on the decision to issue debt is first tested as an independent factor for NDCC 
and DCC firm years. Eq. (3) is modified to include R\&D expense interacted with indicators for the NDCC and DCC firm years as follows:

$$
\begin{gathered}
\Delta \mathrm{DEBT}_{\mathrm{jt}}=\mathrm{a}_{\mathrm{NDCC}}+\mathrm{a}_{\mathrm{DCC}}+\mathrm{b}_{1} \mathrm{DEF}_{\mathrm{jt}}^{\mathrm{NDCC}}+\mathrm{b}_{2} \mathrm{DEF}_{\mathrm{jt}}^{\mathrm{DCC}}+ \\
\mathrm{b}_{3} \mathrm{RD}_{\mathrm{jt}}^{\mathrm{NDCC}}+\mathrm{b}_{4} \mathrm{RD}_{\mathrm{jt}}^{\mathrm{DCC}}+\mathrm{e}_{\mathrm{jt}}
\end{gathered}
$$

$\mathrm{RD}^{\mathrm{NDCC}}\left(\mathrm{RD}^{\mathrm{DCC}}\right)$ represents $\mathrm{R} \& \mathrm{D}$ intensity for NDCC (DCC) firm years, defined as the level of reported R\&D expense divided by total assets. As in eq. (3), $a_{\text {NDCC }}$ and $a_{D C C}$ are predicted to be zero, $b_{1}=1$ (strong-form hypothesis), $b_{2}<1$, and $b_{1}>b_{2}$ (weak-form hypothesis). The coefficient estimates for RD are expected to be negative and significant, indicating that higher information asymmetry about firm risk reduces the amount of debt issued.

As an additional test of the effect of risk on the debt issue decision, debt capacity constraints are controlled by examining the response of debt issues to the financing deficit for NDCC firm years only. R\&D expense again proxies for the degree of asymmetric information about firm risk. NDCC firm years are sorted into thirds of the distribution of R\&D expense, and upper (lower) third of the firm years are identified as those with relatively high (low) information asymmetries about firm risk. Similar to the method for defining eq. (3), indicators of the degree of firm risk for the relatively low (high) risk firm years are used to form $\mathrm{DEF}^{\text {LORISK }}$ and $\mathrm{DEF}^{\mathrm{HIRISK}}$, representing the financing deficit of the firm years in which the degree of firm risk is relatively low and high, respectively. The intercept terms, $\mathrm{a}_{\text {LORISK }}$ and $\mathrm{a}_{\text {HIRISK }}$, correspond to the low- and high-risk firm years, respectively. The regression function used to test the prediction that 
NDCC firms will issue equity when information asymmetry about firm risk is relatively high is the following:

$$
\Delta \mathrm{DEBT}_{\mathrm{jt}}=\mathrm{a}_{\mathrm{LORISK}}+\mathrm{a}_{\text {HIRISK }}+\mathrm{b}_{1} \mathrm{DEF}_{\mathrm{jt}}^{\text {LORISK }}+\mathrm{b}_{2} \mathrm{DEF}_{\mathrm{jt}}^{\text {HIRISK }}+\mathrm{e}_{\mathrm{jt}}
$$

As above, the intercept estimates are expected to be statistically equal to zero. The estimate for $b_{1}$ is expected to be close to 1 , and the estimate for $b_{2}$ is expected to be significantly lower than that for $b_{1}$.

\subsection{Data and sample description}

The data are from Compustat annual active and research files from 1982-2001. The sample construction method generally follows Frank and Goyal (2003). Only publicly traded (Compustat stock ownership codes 0 and 3), U.S.-incorporated firms are included in the sample. Financial firms (SIC 6000-6999) and regulated utilities (SIC 4900-4999) are excluded, as are firms with major mergers (Compustat footnote code AB). Included firm years must have the following data items: Statement of Cash Flows format code (Compustat item 318), long-term debt issuance (item 111), positive net sales (item 12), income before extraordinary items and taxes (item 123), change in cash and equivalents (item 274), book values of assets (item 6) at the end of the previous fiscal year, long-term debt (item 9) at the end of the fiscal year, positive common equity (item 60), common shares outstanding at fiscal year end (item 25), a closing stock price at fiscal year end (item 199), and reported net plant, property, and equipment (item 8) for 
two consecutive years. $R \& D$ intensity is measured as the reported $R \& D$ expense over the period (Compustat item 46) divided by beginning-period assets $(R \& D)^{3}$.

Many balance sheet and cash flow statement observations are set to zero ${ }^{4}$ if recorded as missing or combined with other data items, where appropriate. Control for the influence of IPOs follows Carpenter and Petersen $(2002)^{5}$. Observations prior to and including the first year in which a nonmissing stock price appears in Compustat are deleted. All financial variables are scaled by the book value of beginning-period total assets (where appropriate). When unscaled financial variables are reported as descriptive measures, these are expressed in real terms ${ }^{6}$.

The data are screened for irregularities. Firm years with long-term debt either reported as zero or greater than concurrent total assets are deleted. Firm years with negative values of the current portion of long-term debt are deleted. Negative values of cash dividends are reported for some firm years, and these are deleted as well.

\subsection{Results}

Descriptive statistics for the high growth/large, high growth/small, low growth/large, and low growth/small subsamples of firm years are presented in Table 1. Each subsample is further divided into firm years that are not debt capacity constrained (NDCC) and those that are (DCC). The debt capacity constraint sort variables are the average future financing deficit and the industry-adjusted debt to assets ratio. The

\footnotetext{
${ }^{3} \mathrm{R} \& \mathrm{D}$ expense is set to zero if reported as missing in Compustat.

${ }^{4}$ See Appendix for the list of variables set to zero if recorded in Compustat as not available or combined with another data item.

${ }^{5}$ Carpenter and Petersen (2002) report that the first incidence of a non-missing stock price in Compustat indicates the year in which the firm goes public.

${ }^{6}$ The average annual Producer Price Index, All Commodities, base year=1982, is used to convert variables into real quantities.
} 
average current period financing deficit is statistically larger for the DCC high growth samples, but not in the low growth samples. DCC firms are predicted to issue relatively more equity than NDCC firms, and the average net equity issues are statistically larger in all subsamples except for high growth-large firm years. The financing deficit, average future financing deficit, and R\&D expense of small-high growth DCC firm years are statistically and economically larger than in any other subsample, all of which are predicted to correspond to relatively high equity issues. On average, the DCC small-high growth firm years issue more equity compared to the other subsamples.

\subsubsection{Tests of the basic pecking order model}

The results from estimating eq. (1) for each of the four subsamples partitioned by size and growth are in Table 2. The coefficient estimates for DEF are positive and significant in all subsamples. The estimates for DEF range from 0.68 to 0.83 for the low growth-small, low growth-large, and high growth-large samples, but is 0.17 for the high growth-small firm years. The low value of the coefficient estimate for high growth-small firms is not surprising, given that this sample has a relatively large number of debt capacity constrained firms with high financing deficits, both current and future (see Table 1). The intercept term is statistically equal to zero in the low growth-large and high growth-small samples. Although the intercept term is statistically different from zero in the low growth-small sample, it is economically small. The low growth-large firm results are consistent with Shyam-Sunder and Myers (1999). The low growth-small firm results are a departure from those in Frank and Goyal (2003), and highlight the importance of jointly controlling for size and growth in testing the pecking order model. Overall, the 
results from replicating the Shyam-Sunder and Myers (1999) tests for the four subsamples partitioned jointly by size and growth are consistent with the weak-form predictions of the pecking order model in the sense that firms that are unconstrained by debt capacity concerns will fill the financing deficit primarily with debt issues, and with equity otherwise. However, these tests do not explicitly control for debt capacity constraints and ignore any influence of asymmetric information about firm risk.

\subsubsection{Controlling for debt capacity constraints}

Table 3 reports the results from estimating eq. (3), which is the Shyam-Sunder and Myers regression explicitly controlling for debt capacity constraints via the method in Lemmon and Zender (2002). Compared to the results in Table 2, the notable difference in coefficient estimate is for the high growth-small sample. The estimates for DEF for the high growth-small firm sample are 0.57 and 0.17 for NDCC and DCC firms, respectively. These coefficient estimates are both economically and statistically different (t-statistic is 4.06), but the NDCC estimate for DEF remains relatively low compared to those for the other subsamples. The regression results emphasize the importance of controlling for debt capacity constraints for samples of small, high growth firms.

\subsubsection{Controlling for the nature of asymmetric information}

The first test of whether the nature of asymmetric information matters to the external financing decision is to examine the independent effect of the proxy for asymmetric information about firm risk, R\&D expense, on net debt issues. The estimation results are reported in Table 4. Firm years are again sorted by concerns over 
debt capacity constraints. The coefficient estimates for $\mathrm{RD}$ are significantly negative in all samples, as predicted, indicating that increased asymmetric information about firm risk reduces net debt issues of all firm years. Except for DCC small/high growth firm years, the values of the estimates for RD are relatively small, suggesting that this is a relatively small effect. In the high growth-small sample, the estimates for DEF are again statistically different for the NDCC and DCC firm years. For this sample, the DCC estimate for $\mathrm{RD}$ is -0.25 , which is economically and statistically more negative than the estimate for the NDCC firm years of -0.08 (t-statistic is 3.10 ). This result suggests that asymmetric information about firm risk, approximated by R\&D expense, results in a significantly higher amount of equity issues, as predicted by Myers and Majluf (1984).

The pecking order model predicts that firms without concerns over debt capacity constraints will choose to issue equity when asymmetric information about firm risk dominates that about firm value. The regression results used to test this prediction for NDCC firms are in Table 5. The NDCC firm years are further subdivided by the degree of firm risk, again approximated by R\&D intensity. Controlling for the degree of firm risk produces a substantial difference in the coefficient estimates for DEF between lowand high-risk firms for both the high growth small and large samples. The small/high growth low risk firm years have an estimate for DEF of 0.76 , which is consistent with the Shyam-Sunder and Myers (1999) results for large and mature firms. This estimate is both economically and (weakly) statistically different from the high-risk coefficient estimate for DEF of 0.42 . The degree of information asymmetry about firm risk also has a significant impact on the debt issues of high growth-large firm years. For this sample, 
the low-risk firm coefficient estimate for DEF is 0.81 compared to 0.55 for the high risk years.

To the extent that the level of R\&D expenditure approximates the condition of asymmetric information about firm risk, the test results from estimating eqs. (4) and (5) may be viewed as alternative perspectives on the influence of firm risk on the security issue choice. Both equations condition not only on firm risk, but also on the presence (or absence) of debt capacity constraints. Note that the influence of DEF on net debt issues is statistically significant for the high growth/large firm sample in Table 5 but is insignificant in Table 4. This difference results from the consideration of the extremes of the R\&D expenditure distribution in eq. (5) compared to the full sample in eq. (4). These tests provide evidence that the nature of asymmetric information matters to the external financing decision and help to explain the poor results in previous tests of the pecking order model for small and high growth firms.

\subsection{Robustness of results to alternative variable definitions}

The robustness of the results from estimating eq. (5) are checked against alternative definitions of firm size, risk, and debt capacity constraints. The beginningperiod market value of equity is used to classify firms by size, eq. (5) is re-estimated for this size definition for NDCC firms only, and the results are reported in Table 6. The results for high growth firms, both small and large, are generally robust to the alternative size classification. The difference in coefficient estimates for DEF are strongly statistically different for the high growth small sample, and weakly different in the large/high growth sample (t-statistics are 2.45 and 1.79 , respectively). 
The standard deviation of operating income (EBITDA) is used as an alternative measure of firm risk. The standard deviation of operating income is calculated over each 5-year non-overlapping interval. As above, each firm must have a minimum of three observations to be included in the sample. The results from estimating eq. (5) for NDCC firm years are not robust to this alternative definition of firm risk (see Table 7). The coefficient estimates for DEF are all positive and statistically significant, and the intercept terms are all either insignificant or economically close to zero. There is economic separation between the high growth, small firm low- and high-risk coefficient estimates for DEF ( 0.80 and 0.49 , respectively). However, the relatively high standard error of the estimate for the high growth/small high-risk firm years renders the coefficient estimates statistically equal. The lack of support for the findings in Table 5 using an alternative measure of firm risk may be due to the calculation of the standard deviation of EBITDA using annual data and using relatively few observations (a minimum of three and a maximum of five annual observations). The resulting standard deviation is not a sharp measure of the variability of earnings.

Agca and Mozumdar (2003) use the existence of a bond rating to classify firms as not concerned over debt capacity constraints (NDCC) or otherwise. For robustness, this approach serves as the alternative method of identifying firms as NDCC. The specific method for classifying firms as NDCC or otherwise resembles Almeida, et al., (2004). Debt capacity constrained firm years are those that never had a bond rating over the entire sample period and have positive beginning period long-term debt. Firm years without a debt rating and with zero beginning long-term debt are considered to be NDCC firm years. Table 8 shows the results from estimating eq. (5) using this alternative 
definition of NDCC firm years. The coefficient estimates are generally supportive of those found in Table 5. Low-risk high growth, small firm years use more debt compared to the high-risk counterparts, but overall, these firms are net equity issuers according to the coefficient estimates for DEF ( 0.41 for the low- and 0.11 for the high-risk firm years, t-statistic for the difference in coefficients $=2.73$ ). The differences in the small-firm values of the coefficient estimates for DEF between Tables 5 and 8 are attributed to the inclusion of small firm years that have zero initial long-term debt when debt capacity constraints are defined according to the existence of a public debt rating.

The alternative specifications of the variables in estimating eq. (5) generally produce results that are similar to those in Table 5. In two out of three cases, the high growth/small firm coefficient estimates indicate that a higher degree of asymmetric information about firm risk leads to a greater amount of equity issues to fill the financing deficit. This type of risk appears to matter most to the high growth small firms, and separating firms in this manner results in low-risk firm coefficient estimates in the range of the Shyam-Sunder and Myers (1999) results. When debt capacity constraints are identified by the existence of a bond rating, the coefficient estimates for DEF are economically, but not statistically different between the low- and high-risk firms.

\subsection{Conclusion}

This study asks whether asymmetric information about firm risk matters to the external financing choices of small and growth firms. The results indicate that controlling for firm risk is particularly relevant for small, high growth firms. To the extent that $R \& D$ expense proxies for asymmetric information about firm risk, the 
decision of the small firm to issue equity appears to be conditional on the severity of asymmetric information about firm risk. The empirical results suggest that low-risk small growth firms that are not concerned with debt capacity constraints issue an equivalent proportion of debt as large, mature firms when filling the financing deficit. The results also indicate that high risk firms fund investment primarily with equity, an observation that is consistent with the pecking order model of Myers and Majluf (1984) when debt capacity constraints are non-binding. 


\section{References}

Agca, Senay, and Abon Mozumdar, 2003, Firm Size, Debt Capacity, and the Pecking Order of Financing Choices, Unpublished Working Paper, October 2003.

Akerlof, George A., 1970, The Market for "Lemons": Quality, Uncertainty, and the Market Mechanism, Quarterly Journal of Economics 84, 488-500.

Almeida, Heitor, Murillo Campello, and Michael S.Weisbach, 2004, The Cash Flow Sensitivity of Cash, Journal of Finance 59:4 (August), 1777-1804.

Bhagat, Sanjai, and Ivo Welch, 1995, Corporate Research \& Development Investments: International Comparisons, Journal of Accounting and Economics 19:2-3 (April), 443-70.

Bulan, Laarni, and Zhipeng Yan, 2006, The Pecking Order of Financing in the Firm's Life Cycle, Unpublished Working Paper, December 2006.

Bradley, Michael, Gregg A. Jarrell, and E. Han Kim, 1984, On the Existence of an Optimal Capital Structure: Theory and Evidence, Journal of Finance 39:3 (July), 857878.

Carpenter, Robert E., and Bruce C. Petersen, 2002, Capital Market Imperfections, HighTech Investment, and New Equity Financing, Economic Journal 112:477 (February), 5472.

Chirinko, Robert S., and Anuja R. Singha, 2000, Testing Static Tradeoff Against Pecking Order Models of Capital Structure: A Critical Comment, Journal of Financial Economics 58:3 (December), 417-25.

Frank, Murry Z., and Vidhan K. Goyal, 2003, Testing the Pecking Order Theory of Capital Structure, Journal of Financial Economics 67:2 (February), 217-48.

Hall, Bronwyn H., 2002, The Financing of Research and Development, NBER Working Paper 8773.

Halov, Nickolay and Florian Heider, 2005, Capital Structure, Risk and Asymmetric Information, Unpublished Working Paper, December 2005.

Helwege, Jean, and Nellie Liang, 1996, Is There a Pecking Order? Evidence from a Panel of IPO Firms, Journal of Financial Economics 40:3 (March), 429-58.

Lemmon, Michael L. and Zender, Jaime F., "Debt Capacity and Tests of Capital Structure Theories", working paper, (September 10, 2002).

Myers, Stewart C., 1984, The Capital Structure Puzzle, Journal of Finance 39:3 (July), 575-92. 
Myers, Stewart C., and Nicholas S. Majluf, 1984, Corporate Financing and Investment Decisions When Firms Have Information That Investors Do Not Have, Journal of Financial Economics 13:2 (June), 187-221.

Shyam-Sunder, Lakshmi, and Stewart C. Myers, 1999, Testing Static Tradeoff against Pecking Order Models of Capital Structure, Journal of Financial Economics 51:2 (February), 219-44. 


\section{Appendix: Construction of variables}

All data are from the Compustat annual active and research files. A (*) by the data item indicates that it is set to zero if reported as combined with another item or is missing.

The financing deficit is defined as

$$
\mathrm{DEF}=\mathrm{DIV}+\mathrm{WORKCAP}+\text { INVEST }- \text { CASHFLOW }
$$

Cash dividends, common (DIV) is Compustat item 127

Other variables that define the financing deficit are constructed as follows (Compustat items in parentheses):

\section{Change in working capital (WORKCAP)}

Format code 1: Change in working capital = change in cash and equivalents (item 274) + change in working capital, other (item 236)* + change in current debt (item 301)*

Format codes 2 and 3: Change in working capital = change in cash and equivalents (item 274) - change in working capital, other (item 236)* - change in current debt (item $301)^{*}$

Format code 7: Change in working capital $=$ change in cash and equivalents (item 274) - change in accounts receivable (item 302$)^{*}$ - change in inventory (item 303$)^{*}$ - change in accounts payable (item 304$)^{*}$ - net change in assets and liabilities, other (item 307)* financing activities, other (item 312$)^{*}$ - changes in current debt (item 301)*

\section{Net investment (INVEST)}

Format codes 1, 2, 3: Net investments $=$ capital expenditures (item 128)* + increase in investments (item 113)* + acquisitions (item 129)* - uses of funds, other (item 219)* sale of plant, property, and equipment (item 107)* - sale of investments (item 109)*

Format code 7: Net investments $=$ capital expenditures $(\text { item } 128)^{*}+$ increase in investments (item 113)* + acquisitions (item 129)* - sale of plant, property, and equipment (item 107)* - sale of investments (item 109)* - short term investments, change (item 309)* - investing activities, other (item 310)*

\section{Internal cash flow (CASHFLOW)}

Format codes 1, 2, 3: Cash flow after interest and taxes = income before taxes (item 123) + extraordinary items and discontinued operations (item 124)* + depreciation and amortization (item 125)* + deferred taxes (item 126)* + equity in net loss (item 106)* + gain (loss)* from sales of PPE and other investments (item 213)* + other funds from operations (item 217)* + sources of funds, other (item 218)* 
Format code 7: Cash flow after interest and taxes $=$ income before taxes (item 123) + extraordinary items and discontinued operations (item 124)* + depreciation and amortization (item 125)* + deferred taxes (item 126)* + equity in net loss (item 106)* + gain (loss)* from sales of PPE and other investments (item 213)* + other funds from operations (item 217)* + exchange rate effect (item 314 )*

Net debt issued = long-term debt issuance(item 111)-long-term debt reduction(item $114)^{*}$

Net equity issued $=$ sale of common stock $($ item 108$) *-$ stock repurchases(item 115)*

Market-to-book (MTB) is the market value of assets to the book value of assets,

$\mathrm{MTB}=1+[$ (closing price per share of common stock at fiscal year end (item 199) multiplied by the number of common shares outstanding at fiscal year end (item 25) common equity, total (item 60)]/total assets (item 6) 


\section{Table 1.1: Descriptive Statistics}

Annual data are from Compustat from 1982-2001. High (low) growth, large (small) firm years are those in the top (bottom) third of the distributions of beginning-period market-to-book and real total assets. Firms with moderate expected future financing needs and low initial leverage position (relative to the industry) are classified as not debt capacity constrained (NDCC). Firms with high expected future financing needs are classified as debt capacity constrained (DCC) regardless of their initial leverage position relative to the industry. Market-to-book is the beginning-period market value of assets divided by beginning assets. The financing deficit $(\mathrm{DEF})=$ cash dividends + change in working capital + net investment - internal cash flow Cash dividends are ordinary cash dividends paid on common stock over the fiscal year. For Statement of Cash Flows (SCF) format codes 1(2,3)[7], change in working capital = items 274+236+301(274+236301)[274-302-303-304-307-312-301]. For SCF format codes 1,2,3[7], internal cash flow = items 123 $+124+125+126+106+213+217+218[123+124+125+126+106+213+217+314]$. For SCF format codes $1,2,3[7]$, net investment $=$ items $128+113+129-219-107-109$ [128+113+129-107-309-310]. Net debt issues $=$ long-term debt issued (item 111) - long-term debt reductions (item 114). Net equity issues $=$ sale of common and preferred stock (item 108) - stock repurchases (item 115). Where appropriate, all variables are scaled by the beginning-period book value of assets.

\section{Panel A: High growth, large firm years}

\begin{tabular}{lccccc}
\hline & \multicolumn{2}{c}{ NDCC } & \multicolumn{2}{c}{ DCC } & Difference \\
& Mean & Std. Error & Mean & Std. Error & in Means \\
& z-statistic \\
\hline Total assets & $3,533.44$ & $19,818.71$ & $2,877.44$ & $6,959.36$ & 0.92 \\
Market-to-book & 2.81 & 1.53 & 2.89 & 2.61 & -1.14 \\
Sales growth & 7.25 & 1.22 & 7.16 & 1.29 & 1.92 \\
Long term debt & 0.09 & 0.10 & 0.17 & 0.15 & -20.09 \\
Operating income & 0.18 & 0.09 & 0.17 & 0.11 & 1.30 \\
Financing deficit & 0.02 & 0.07 & 0.05 & 0.23 & -6.17 \\
Future deficit & 0.02 & 0.02 & 0.06 & 0.20 & -11.87 \\
R\&D expense & 0.04 & 0.06 & 0.04 & 0.07 & -1.48 \\
Net debt issues & 0.02 & 0.06 & 0.05 & 0.18 & -8.10 \\
Net equity issues & 0.00 & 0.04 & 0.00 & 0.12 & 0.78 \\
\hline
\end{tabular}

Panel B: High growth, small firm years

\begin{tabular}{|c|c|c|c|c|c|}
\hline & \multicolumn{2}{|c|}{$\begin{array}{l}\text { NDCC } \\
\mathrm{N}=1,045\end{array}$} & \multicolumn{2}{|c|}{$\begin{array}{c}\text { DCC } \\
\mathrm{N}=4,142\end{array}$} & \multirow{2}{*}{$\begin{array}{c}\text { Difference } \\
\text { in Means } \\
\text { z-statistic }\end{array}$} \\
\hline & Mean & Std. Error & Mean & Std. Error & \\
\hline Total assets & 29.66 & 11.93 & 28.59 & 12.37 & 2.58 \\
\hline Market-to-book & 3.00 & 1.66 & 3.34 & 2.74 & -5.07 \\
\hline Sales growth & 3.58 & 0.77 & 3.24 & 1.17 & 11.29 \\
\hline Long term debt & 0.03 & 0.05 & 0.10 & 0.14 & -27.26 \\
\hline Operating income & 0.15 & 0.19 & 0.08 & 0.33 & 9.62 \\
\hline Financing deficit & 0.03 & 0.08 & 0.29 & 0.68 & -24.46 \\
\hline Future deficit & 0.02 & 0.02 & 0.21 & 0.33 & -36.42 \\
\hline$R \& D$ expense & 0.08 & 0.11 & 0.12 & 0.19 & -8.21 \\
\hline Net debt issues & 0.01 & 0.06 & 0.05 & 0.28 & -9.34 \\
\hline Net equity issues & 0.02 & 0.05 & 0.23 & 0.61 & -22.41 \\
\hline
\end{tabular}


Table 1.1 (continued)

Panel C: Low growth, large firm years

\begin{tabular}{|c|c|c|c|c|c|}
\hline & \multicolumn{2}{|c|}{$\begin{array}{c}\text { NDCC } \\
\mathrm{N}=581\end{array}$} & \multicolumn{2}{|c|}{$\begin{array}{c}\text { DCC } \\
\mathrm{N}=3,602\end{array}$} & \multirow{2}{*}{$\begin{array}{c}\text { Difference } \\
\text { in Means } \\
\text { z-statistic }\end{array}$} \\
\hline & Mean & Std. Error & Mean & Std. Error & \\
\hline Total assets & $4,566.64$ & $13,864.42$ & $3,525.04$ & $15,141.12$ & 1.66 \\
\hline Market-to-book & 0.98 & 0.12 & 0.99 & 0.10 & -2.04 \\
\hline Sales growth & 7.10 & 1.48 & 6.86 & 1.31 & 3.69 \\
\hline Long term debt & 0.15 & 0.11 & 0.30 & 0.16 & -27.93 \\
\hline Operating income & 0.09 & 0.08 & 0.09 & 0.07 & -1.71 \\
\hline Financing deficit & 0.02 & 0.06 & 0.02 & 0.12 & -0.05 \\
\hline Future deficit & 0.02 & 0.02 & 0.04 & 0.13 & -7.32 \\
\hline R\&D expense & 0.01 & 0.03 & 0.01 & 0.02 & 0.99 \\
\hline Net debt issues & 0.01 & 0.06 & 0.01 & 0.11 & 0.69 \\
\hline Net equity issues & -0.0002 & 0.03 & 0.003 & 0.04 & -2.47 \\
\hline
\end{tabular}

Panel D: Low growth, small firm years

\begin{tabular}{lccccc}
\hline & \multicolumn{2}{c}{ NDCC } & \multicolumn{2}{c}{ DCC } & $\begin{array}{c}\text { Difference } \\
\text { N=1,191 }\end{array}$ \\
& Mean & Std. Error & Mean & Std. Error & $\begin{array}{c}\text { in Means } \\
\text { z-statistic }\end{array}$ \\
\hline Total assets & 28.40 & 12.06 & 29.32 & 12.39 & -2.33 \\
Market-to-book & 0.87 & 0.16 & 0.91 & 0.15 & -8.20 \\
Sales growth & 3.37 & 0.96 & 3.43 & 0.93 & -1.72 \\
Long term debt & 0.07 & 0.09 & 0.18 & 0.16 & -31.56 \\
Operating income & 0.06 & 0.12 & 0.08 & 0.11 & -6.90 \\
Financing deficit & 0.02 & 0.08 & 0.02 & 0.20 & -0.49 \\
Future deficit & 0.02 & 0.02 & 0.03 & 0.14 & -5.46 \\
R\&D expense & 0.03 & 0.06 & 0.02 & 0.05 & 5.17 \\
Net debt issues & 0.01 & 0.07 & 0.01 & 0.17 & 1.07 \\
Net equity issues & 0.00 & 0.03 & 0.01 & 0.09 & -3.38 \\
\hline
\end{tabular}




\section{Table 1.2: Shyam-Sunder and Myers Replication}

Annual data are from Compustat from 1982-2001. $\triangle$ DEBT is the difference between long-term debt issues and reductions as reported in the Statement of Cash Flows (or similar flow of funds statements). DEF is the difference between internal funds and investments over the period. All variables are scaled by beginning-period total assets. Low (high) growth, small (large) firm years are those occurring in the intersection between the bottom (top) third of the market-to-book assets distribution and the bottom (top) third of the beginning-period total assets distribution. Asymptotic t-statistics are in parentheses.

$$
\Delta \mathrm{DEBT}_{\mathrm{jt}}=\mathrm{b}_{0}+\mathrm{b}_{1} \mathrm{DEF}_{\mathrm{jt}}+\mathrm{e}_{\mathrm{jt}}
$$

\begin{tabular}{lccc}
\hline & Intercept & $\mathbf{D E F}$ & $\mathbf{R}^{2}$ \\
\hline Low growth, small & -0.01 & 0.74 & 0.74 \\
& $(-5.86)$ & $(16.78)$ & \\
Low growth, large & -0.001 & 0.83 & 0.84 \\
& $(-1.57)$ & $(48.98)$ & \\
High growth, small & 0.004 & 0.17 & 0.18 \\
& $(0.80)$ & $(7.14)$ & \\
High growth, large & 0.02 & 0.68 & 0.73 \\
& $(11.80)$ & $(18.43)$ & \\
\hline
\end{tabular}




\section{Table 1.3: Debt Issues Controlling for Debt Capacity}

Annual data are from Compustat from 1982-2001. $\triangle \mathrm{DEBT}$ is the difference between long-term debt issues and reductions as reported in the Statement of Cash Flows (or similar flow of funds statements). DEF is the difference between internal funds and investment over the period. All variables are scaled by beginning-period total assets. Low (high) growth, small (large) firm years are those occurring in the intersection between the bottom (top) third of the market-to-book assets distribution and the bottom (top) third of the beginning-period total assets distribution. Firms with moderate expected future financing needs and low initial leverage position (relative to the industry) are classified as not debt capacity constrained (NDCC). Firms with high expected future financing needs are classified as debt capacity constrained (DCC) regardless of their initial leverage position relative to the industry. Asymptotic t-statistics are in parentheses.

$$
\Delta \mathrm{DEBT}_{\mathrm{jt}}=\mathrm{a}_{\mathrm{NDCC}}+\mathrm{a}_{\mathrm{DCC}}+\mathrm{b}_{1} \mathrm{DEF}_{\mathrm{jt}}^{\mathrm{NDCC}}+\mathrm{b}_{2} \mathrm{DEF}_{\mathrm{jt}}^{\mathrm{DCC}}+\mathrm{e}_{\mathrm{jt}}
$$

\begin{tabular}{lcccccc}
\hline & Int. $^{\text {NDCC }}$ & Int. $^{\text {DCC }}$ & DEF $^{\text {NDCC }}$ & DEF $^{\text {DCC }}$ & $\mathbf{R}^{2}$ & $\begin{array}{c}\text { t-stat } \\
\mathbf{b}_{\mathbf{1}}-\mathbf{b}_{\mathbf{2}}\end{array}$ \\
\hline Low growth, small & -0.001 & -0.01 & 0.67 & 0.74 & 0.74 & -0.85 \\
& $(-0.49)$ & $(-5.93)$ & $(14.92)$ & $(16.29)$ & & \\
Low growth, large & 0.001 & -0.001 & 0.81 & 0.83 & 0.84 & -0.24 \\
& $(0.99)$ & $(-1.92)$ & $(21.99)$ & $(47.19)$ & & \\
High growth, small & -0.01 & 0.004 & 0.57 & 0.17 & 0.21 & 4.06 \\
& $(-3.35)$ & $(0.63)$ & $(7.80)$ & $(6.95)$ & & \\
High growth, large & 0.01 & 0.02 & 0.74 & 0.67 & 0.75 & 0.81 \\
& $(3.55)$ & $(11.87)$ & $(17.25)$ & $(18.05)$ & & \\
\hline
\end{tabular}




\section{Table 1.4: Debt Issues Controlling for Debt Capacity and Risk}

Annual data are from Compustat from 1982-2001. $\triangle$ DEBT is the difference between long-term debt issues and reductions as reported in the Statement of Cash Flows (or similar flow of funds statements). DEF is the difference between internal funds and investment over the period. R\&D is research and development expense over the period (item 46). All variables are scaled by beginning-period total assets. Low (high) growth, small (large) firm years are those occurring in the intersection between the bottom (top) third of the market-to-book assets distribution and the bottom (top) third of the beginning-period total assets distribution. Firms with moderate expected future financing needs and low initial leverage position (relative to the industry) are classified as not debt capacity constrained (NDCC). Firms with high expected future financing needs are classified as debt capacity constrained (DCC) regardless of their initial leverage position relative to the industry. Asymptotic t-statistics are in parentheses.

$$
\Delta \mathrm{DEBT}_{\mathrm{jt}}=\mathrm{a}_{\mathrm{NDCC}}+\mathrm{a}_{\mathrm{DCC}}+\mathrm{b}_{1} \mathrm{DEF}_{\mathrm{jt}}{ }^{\mathrm{NDCC}}+\mathrm{b}_{2} \mathrm{DEF}_{\mathrm{jt}}^{\mathrm{DCC}}+\mathrm{b}_{3} \mathrm{RD}_{\mathrm{jt}}{ }^{\mathrm{NDCC}}+\mathrm{b}_{4} \mathrm{RD}_{\mathrm{jt}}{ }^{\mathrm{DCC}}+\mathrm{e}_{\mathrm{jt}}
$$

\begin{tabular}{lcccccccc}
\hline & Int. $^{\text {NDCC }}$ & Int. $^{\text {DCC }}$ & $\mathbf{D E F}^{\text {NDCC }}$ & $\mathbf{D E F}^{\text {DCC }}$ & $\mathbf{R D}^{\text {NDCC }}$ & $\mathbf{R D}^{\text {DCC }}$ & $\mathbf{R}^{2}$ & $\begin{array}{c}\mathbf{t}-\mathbf{s t a t} \\
\mathbf{b}_{\mathbf{1}}-\mathbf{b}_{2}\end{array}$ \\
\hline Low growth, small & 0.001 & -0.004 & 0.67 & 0.75 & -0.04 & -0.11 & 0.73 & -0.87 \\
& $(0.60)$ & $(-2.94)$ & $(14.92)$ & $(16.43)$ & $(-2.85)$ & $(-2.35)$ & & \\
Low growth, large & 0.002 & -0.001 & 0.81 & 0.83 & -0.06 & -0.06 & 0.84 & -0.25 \\
& $(1.51)$ & $(-0.86)$ & $(22.00)$ & $(47.21)$ & $(-1.78)$ & $(-1.98)$ & & \\
High growth, small & 0.00 & 0.03 & 0.58 & 0.20 & -0.08 & -0.25 & 0.23 & 3.90 \\
& $(-0.05)$ & $(4.95)$ & $(8.15)$ & $(7.45)$ & $(-5.12)$ & $(-6.13)$ & & \\
High growth, large & 0.01 & 0.02 & 0.74 & 0.68 & -0.13 & -0.11 & 0.76 & 0.82 \\
& $(5.95)$ & $(11.26)$ & $(17.68)$ & $(18.34)$ & $(-7.05)$ & $(-3.31)$ & & \\
\hline
\end{tabular}




\section{Table 1.5: Debt Issues Controlling for Debt Capacity and Risk, NDCC Firms Only}

Annual data are from Compustat from 1982-2001. $\triangle \mathrm{DEBT}$ is the difference between long-term debt issues and reductions as reported in the Statement of Cash Flows (or similar flow of funds statements). DEF is the difference between internal funds and investment over the period. All variables are scaled by beginning-period total assets. Low (high) growth, small (large) firm years are those occurring in the intersection between the bottom (top) third of the market-to-book assets distribution and the bottom (top) third of the beginning-period total assets distribution. Firms with moderate expected future financing needs and low initial leverage position (relative to the industry) are classified as not debt capacity constrained (NDCC). Low (high) risk NDCC firm years are those in the lower (upper) third of the R\&D expense distribution. Asymptotic t-statistics are in parentheses.

$$
\Delta \mathrm{DEBT}_{\mathrm{jt}}=\mathrm{a}_{\text {LORISK }}+\mathrm{a}_{\text {HIRISK }}+\mathrm{b}_{1} \mathrm{DEF}_{\mathrm{jt}}^{\text {LORISK }}+\mathrm{b}_{2} \mathrm{DEF}_{\mathrm{jt}}^{\text {HIRISK }}+\mathrm{e}_{\mathrm{jt}}
$$

\begin{tabular}{|c|c|c|c|c|c|c|}
\hline & Int. $^{\text {LORISK }}$ & Int. ${ }^{\text {HIRISK }}$ & DEF ${ }^{\text {LORISK }}$ & DEF ${ }^{\text {HIRISK }}$ & $\mathbf{R}^{2}$ & $\begin{array}{l}\text { t-stat } \\
\mathbf{b}_{1}-\mathbf{b}_{2}\end{array}$ \\
\hline Low growth, small & $\begin{array}{l}-0.001 \\
(-0.54)\end{array}$ & $\begin{array}{l}-0.002 \\
(-1.37)\end{array}$ & $\begin{array}{c}0.70 \\
(12.45)\end{array}$ & $\begin{array}{c}0.62 \\
(8.26)\end{array}$ & 0.50 & 0.57 \\
\hline Low growth, large & $\begin{array}{l}0.001 \\
(0.52)\end{array}$ & $\begin{array}{l}0.001 \\
(0.11)\end{array}$ & $\begin{array}{c}0.83 \\
(19.91)\end{array}$ & $\begin{array}{c}0.61 \\
(3.86)\end{array}$ & 0.46 & 1.12 \\
\hline High growth, small & $\begin{array}{l}-0.003 \\
(-1.69)\end{array}$ & $\begin{array}{c}-0.01 \\
(-2.31)\end{array}$ & $\begin{array}{c}0.76 \\
(12.59)\end{array}$ & $\begin{array}{c}0.42 \\
(3.30)\end{array}$ & 0.53 & 1.83 \\
\hline High growth, large & $\begin{array}{c}0.01 \\
(3.26)\end{array}$ & $\begin{array}{l}-0.001 \\
(-0.48)\end{array}$ & $\begin{array}{c}0.81 \\
(14.14)\end{array}$ & $\begin{array}{c}0.55 \\
(7.63)\end{array}$ & 0.60 & 2.03 \\
\hline
\end{tabular}




\section{Table 1.6: Robustness to Alternative Definition of Firm Size, NDCC Firms Only}

Annual data are from Compustat from 1982-2001. $\triangle \mathrm{DEBT}$ is the difference between long-term debt issues and reductions as reported in the Statement of Cash Flows (or similar flow of funds statements). DEF is the difference between internal funds and investment over the period. All variables are scaled by beginning-period total assets. Low (high) growth, small (large) firm years are those occurring in the intersection between the bottom (top) third of the market-to-book assets distribution and the bottom (top) third of the beginning-period market value of equity distribution. Firms with moderate expected future financing needs and low initial leverage position (relative to the industry) are classified as not debt capacity constrained (NDCC). Low (high) risk NDCC firm years are those in the lower (upper) third of the R\&D expense distribution. Asymptotic t-statistics are in parentheses.

$$
\Delta \mathrm{DEBT}_{\mathrm{jt}}=\mathrm{a}_{\mathrm{LORISK}}+\mathrm{a}_{\text {HIRISK }}+\mathrm{b}_{1} \mathrm{DEF}_{\mathrm{jt}}^{\text {LORISK }}+\mathrm{b}_{2} \mathrm{DEF}_{\mathrm{jt}}^{\text {HIRISK }}+\mathrm{e}_{\mathrm{jt}}
$$

\begin{tabular}{|c|c|c|c|c|c|c|}
\hline & Int. $^{\text {LORISK }}$ & Int. ${ }^{\text {HIRISK }}$ & DEF ${ }^{\text {LORISK }}$ & DEF ${ }^{\text {HIRISK }}$ & $\mathbf{R}^{2}$ & $\begin{array}{l}\text { t-stat } \\
\mathbf{b}_{1}-\mathbf{b}_{2}\end{array}$ \\
\hline Low growth, small & $\begin{array}{l}0.001 \\
(0.64)\end{array}$ & $\begin{array}{l}-0.001 \\
(-0.37)\end{array}$ & $\begin{array}{c}0.67 \\
(10.06)\end{array}$ & $\begin{array}{c}0.65 \\
(10.38)\end{array}$ & 0.51 & 0.15 \\
\hline Low growth, large & $\begin{array}{l}0.004 \\
(2.14)\end{array}$ & $\begin{array}{l}0.003 \\
(0.53)\end{array}$ & $\begin{array}{c}0.81 \\
(15.30)\end{array}$ & $\begin{array}{c}0.65 \\
(4.49)\end{array}$ & 0.44 & 0.81 \\
\hline High growth, small & $\begin{array}{l}-0.006 \\
(-1.72)\end{array}$ & $\begin{array}{c}0.00 \\
(-0.44)\end{array}$ & $\begin{array}{c}0.79 \\
(9.46)\end{array}$ & $\begin{array}{c}0.33 \\
(3.12)\end{array}$ & 0.52 & 2.45 \\
\hline High growth, large & $\begin{array}{l}0.005 \\
(2.53)\end{array}$ & $\begin{array}{l}-0.004 \\
(-2.91)\end{array}$ & $\begin{array}{c}0.74 \\
(11.85)\end{array}$ & $\begin{array}{c}0.49 \\
(6.29)\end{array}$ & 0.50 & 1.79 \\
\hline
\end{tabular}




\section{Table 1.7: Robustness to Alternative Definition of Firm Risk, NDCC Firms Only}

Annual data are from Compustat from 1982-2001. $\triangle$ DEBT is the difference between long-term debt issues and reductions as reported in the Statement of Cash Flows (or similar flow of funds statements). DEF is the difference between internal funds and investment over the period. All variables are scaled by beginning-period total assets. Low (high) growth, small (large) firm years are those occurring in the intersection between the bottom (top) third of the market-to-book assets distribution and the bottom (top) third of the beginning-period total assets distribution. Firms with moderate expected future financing needs and low initial leverage position (relative to the industry) are classified as not debt capacity constrained (NDCC). Low (high) risk NDCC firm years are those in the lower (upper) third of the distribution of the standard deviation of operating income (EBITDA) calculated over 5-year non-overlapping intervals. Asymptotic t-statistics are in parentheses.

$$
\Delta \mathrm{DEBT}_{\mathrm{jt}}=\mathrm{a}_{\text {LORISK }}+\mathrm{a}_{\text {HIRISK }}+\mathrm{b}_{1} \mathrm{DEF}_{\mathrm{jt}}^{\text {LORISK }}+\mathrm{b}_{2} \mathrm{DEF}_{\mathrm{jt}}^{\text {HIRISK }}+\mathrm{e}_{\mathrm{jt}}
$$

\begin{tabular}{lcccccc}
\hline & Int. $^{\text {LORISK }}$ & Int. $^{\text {HIRISK }}$ & DEF $^{\text {LORISK }}$ & DEF $^{\text {HIRISK }}$ & $\mathbf{R}^{2}$ & $\begin{array}{l}\text { t-stat } \\
\mathbf{b}_{\mathbf{1}}-\mathbf{b}_{2}\end{array}$ \\
\hline Low growth, small & 0.004 & -0.002 & 0.65 & 0.66 & 0.50 & -0.05 \\
& $(1.64)$ & $(-1.34)$ & $(6.10)$ & $(10.05)$ & & \\
Low growth, large & 0.004 & 0.000 & 0.80 & 0.88 & 0.46 & -0.68 \\
& $(2.20)$ & $(0.00)$ & $(13.97)$ & $(16.12)$ & & \\
High growth, small & -0.004 & -0.01 & 0.80 & 0.49 & 0.53 & 1.51 \\
& $(-2.03)$ & $(-2.51)$ & $(7.54)$ & $(4.73)$ & & \\
High growth, large & 0.01 & -0.002 & 0.78 & 0.65 & 0.60 & 1.02 \\
& $(3.23)$ & $(-0.45)$ & $(13.00)$ & $(10.15)$ & & \\
\hline
\end{tabular}




\section{Table 1.8: Robustness to Alternative Definition of Debt Capacity, NDCC Firms Only}

Annual data are from Compustat from 1982-2001. $\triangle$ DEBT is the difference between long-term debt issues and reductions as reported in the Statement of Cash Flows (or similar flow of funds statements). DEF is the difference between internal funds and investment over the period. All variables are scaled by beginning-period total assets. Low (high) growth, small (large) firm years are those occurring in the intersection between the bottom (top) third of the market-to-book assets distribution and the bottom (top) third of the beginning-period total assets distribution. Firms with moderate expected future financing needs and low initial leverage position (relative to the industry) are classified as not debt capacity constrained (NDCC). Low risk NDCC firms are those that have had at least one debt rating over the sample period. High risk NDCC firms are those that have never had rated debt over the sample period. Asymptotic tstatistics are in parentheses.

$$
\Delta \text { DEBT }_{\mathrm{jt}}=\mathrm{a}_{\text {LORISK }}+\mathrm{a}_{\text {HIRISK }}+\mathrm{b}_{1} \mathrm{DEF}_{\mathrm{jt}}^{\text {LORISK }}+\mathrm{b}_{2} \mathrm{DEF}_{\mathrm{jt}}^{\text {HIRISK }}+\mathrm{e}_{\mathrm{jt}}
$$

\begin{tabular}{lcccccc}
\hline & Int. $^{\text {LORISK }}$ & Int. $^{\text {HIRISK }}$ & DEF $^{\text {LORISK }}$ & DEF $^{\text {HIRISK }}$ & $\mathbf{R}^{2}$ & $\begin{array}{l}\mathbf{t}^{\text {t-Stat }} \\
\mathbf{b}_{\mathbf{1}}-\mathbf{b}_{\mathbf{2}}\end{array}$ \\
\hline Low growth, small & $\begin{array}{c}0.008 \\
(2.19)\end{array}$ & $\begin{array}{c}0.000 \\
(0.07)\end{array}$ & $\begin{array}{c}0.41 \\
(4.27)\end{array}$ & $\begin{array}{c}0.64 \\
(2.61)\end{array}$ & 0.64 & -0.67 \\
& & & & & \\
Low growth, large & -0.001 & 0.000 & 0.83 & 0.72 & 0.69 & 1.05 \\
& $(-1.00)$ & $(0.22)$ & $(32.20)$ & $(10.09)$ & & \\
High growth, small & 0.003 & 0.00 & 0.41 & 0.11 & 0.33 & 2.73 \\
& $(0.23)$ & $(0.19)$ & $(5.64)$ & $(3.05)$ & & \\
High growth, large & 0.021 & 0.010 & 0.65 & 0.73 & 0.73 & -0.78 \\
& $(7.06)$ & $(3.49)$ & $(13.70)$ & $(11.32)$ & & \\
\hline
\end{tabular}




\title{
Chapter 2
}

\section{The Sensitivity of Investment to Internal Funds When the Costs of External Funds Differ}

\begin{abstract}
This study tests and finds support for the notion that financially constrained firms have investment spending that is relatively more sensitive to internal funds compared to firms that face relatively fewer external capital market frictions. External capital market frictions are approximated by the costs of external funds. Examining the investmentinternal funds sensitivity relative to the cost of external funds is the main contribution of this study. The empirical results suggest that financially constrained firms with the highest security issue costs have the highest investment-internal funds sensitivity. However, this sensitivity is not driven by internal cash flow, but rather by the beginningperiod cash balance. Cash flow is positively correlated with investment spending, but is generally not more relevant to the investment spending of financially constrained firms. The analysis shows that the beginning-period stock of cash is relatively more important to investment spending for financially constrained firms for which security issue costs are high. However, the results also suggest that the importance of cash to investment may indicate growth opportunities not captured by the proxy for Tobin's Q. The results are robust to alternative approximations of the constraint factor.
\end{abstract}




\subsection{Introduction}

The credit channel literature argues that monetary policy disproportionately affects investment spending of firms that have relatively restricted access to external capital markets when attempting to fill the gap between investment demand and internal funds availability. One piece of evidence in support of the credit channel is that constrained firms have investment spending that is relatively more sensitive to current cash flow. Grouping firms by dividend payout, Fazzari, Hubbard, and Petersen (1988) find that the investment spending of firms with comparatively limited internal funds (as suggested by low dividend payout) is more sensitive to current cash flow compared to firms with relatively large dividend payouts. This finding has motivated numerous studies that question the validity of the results.

Empirical challenges to Fazzari, Hubbard, and Petersen (1988) include Kaplan and Zingales (1997), who stratify the low dividend payout sample of Fazzari, Hubbard, and Petersen via a set of internal liquidity measures and find that firms with greater internal liquidity have investment spending that is relatively more sensitive to current cash flow ${ }^{7}$. Gomes (2001) and Alti (2003) demonstrate that the observed investmentcash flow sensitivity not unique to financially constrained firms. Further, Alti shows that cash flow is informative about investment opportunities, regardless of financing frictions.

Taking a different approach to studying the effects of financing constraints on firm behavior, Almeida, Campello, and Weisbach (2004) find that financially constrained firms exhibit cash sensitivity to cash flow, where other firms do not exhibit this feature. In this context, constrained firms, or firms that have restricted access to external capital 
markets, bank cash for investment and other purposes. Fazzari, et al. (1988) also postulate that cash is important for constrained firms, and observe a positive relationship between the stock of cash and investment for constrained firms, but not for firms likely to face fewer external financing frictions. The importance of cash to firms that face frictions in financial markets is implicitly indicated in Kaplan and Zingales (2000) and Fazzari, et al. (2000), who focus on internal funds sensitivity of investment spending. Fazzari, et al. suggest that investment-internal funds sensitivity depends on an external funds cost differential, where firms with constrained access to external capital markets face a relative higher cost of funds. Although an external funds cost differential is believed to drive the predicted differences of investment-internal funds sensitivity between constrained and unconstrained firms, this issue has not been addressed directly in previous empirical tests.

The purpose of this study is to examine whether or not investment-internal funds sensitivity is driven by capital market frictions that result in higher costs of external financing. This is a test of the theory in Kaplan and Zingales $(1997,2000)$ and Fazzari, Hubbard, and Petersen $(1988,2000)$ and is the primary contribution of this study. Internal funds are defined as the sum of current-period internal cash flow and the beginning-period cash balance. Costs of external financing are approximated on three dimensions: firm size, issue type, and proceeds of the issue. The influence of internal cash flow and the beginning-period cash balance on current period investment is examined for each cost category. An additional contribution is the investigation of the role of cash as a liquidity factor versus an indicator of investment opportunities not

\footnotetext{
${ }^{7}$ Other studies that investigate investment sensitivity to cash flow include Cummins, Hassett, and Oliner
} (1999) and Cleary (1999). 
captured by the proxy for Tobin's Q. Finally, this study addresses whether commonly used methods of identifying financially constrained firms are linked to the base explanation of higher capital market frictions.

The results suggest that firms likely to face higher capital market frictions invest proportionately more, have lower internal cash flow but hold a significantly greater percentage of total assets in cash. As a source of funds for investment spending, the importance of cash flow to investment spending is not unique to constrained firms, supporting the findings in Gomes (2001) and Alti (2003). Cash is relatively more important to firms facing the highest security issue costs or that are financially constrained, consistent with Almeida, et al. (2004). However, tests that attempt to distinguish between the role of cash for liquidity purposes and as indicator of investment opportunities do not convincingly support the idea that cash is relatively more important to constrained firms for liquidity purposes. The results from testing investment-internal funds responses for the commonly used methods of identifying financially constrained firms are generally consistent with the security issue cost explanation.

The remainder of this paper is organized as follows: hypotheses are developed in section 2 , and the research method is discussed in section 3 . The data and sample are described in section 4. Results are presented and discussed in section 5, and alternative methods of identifying financially constrained firms are explained and examined section 6. Section 7 concludes. 


\subsection{Hypothesis development}

The theoretical relationship between financing constraints and investment sensitivities to internal funds is described in Kaplan and Zingales $(1997,2000)$ and Fazzari, Hubbard, and Petersen (1988, 2000). Kaplan and Zingales (hereafter, KZ) illustrate this relationship with a one-period investment choice problem in which the firm chooses its level of investment, I, to maximize profits. The revenue generated from investment is given by the production function, $F(I)$, where $F_{1}>0, F_{11}<0$. The implicit assumption in this one-period production function is that output responds to investment within one period. Investment is financed by internal funds, W, or external funds, E. For simplicity, KZ set the opportunity cost of internal capital equal to 1 . The cost of external funds, $\mathrm{C}(\mathrm{E}, \mathrm{k})$, is described by the dollar amount of external funds, E, and the cost wedge between internal and external funds, $\mathrm{k}$. The cost function is assumed to be increasing in both arguments, $\mathrm{C}_{1}>0, \mathrm{C}_{2}>0$, and the marginal cost is assumed to be increasing in the dollar amount of external funds, or $\mathrm{C}_{11}>0$.

Over the period, the firm chooses I to

$$
\max F(I)-C(E, k)-I \text {, where } I=W+E \text {. }
$$

The first-order condition is

$$
\mathrm{F}_{1}(\mathrm{I})=1+\mathrm{C}_{1}(\mathrm{I}-\mathrm{W}, \mathrm{k})
$$

$\mathrm{KZ}$ describe the effect of the availability of internal funds on investment by implicitly differentiating the first-order condition:

$$
\frac{d I}{d W}=\frac{C_{11}}{C_{11}-F_{11}}>0
$$


The above result predicts that investment unambiguously increases with the availability of internal funds. Note that the result in eq. (1) holds only when $E>0$.

When is investment relatively more responsive to internal funds? To distinguish between firms, a firm is defined as financially constrained (FC) when it faces relatively high capital market frictions and must rely on external capital markets to finance investment spending. Analogously, a firm that is not financially constrained (NFC) when it faces relatively low external capital market frictions. Following directly from eq. (1), Fazzari, et al. (2000) state that a necessary and sufficient condition for $\mathrm{dI} / \mathrm{dW}$ to be greater for financially constrained firms is

$$
\frac{C_{11}^{\text {Constrained }}}{C_{11}^{\text {Unconstrained }}}>\frac{F_{11}^{\text {Constrained }}}{F_{11}^{\text {Unconstrained }}}
$$

where $\mathrm{C}_{11}$ is the slope of the marginal cost of external financing curve and $\mathrm{F}_{11}$ is the slope of the marginal revenue curve. If condition (2) holds, then investment as a function of internal funds, I(W), must be concave increasing. However, (2) relates internal funds to costs of external funds and revenues from investment. Since there is no a priori reason to expect constrained firms to have systematically higher rates of return on invested funds, all else equal, the necessary and sufficient condition for $\mathrm{dI} / \mathrm{dW}$ greater for constrained firms is

$$
C_{11}^{\text {Constrained }}>C_{11}^{\text {Unconstrained }}
$$

In other words, the marginal cost of external financing must increase more sharply for FC firms to have investment spending that is relatively more sensitive to internal funds.

The preceding discussion suggests the following questions: 1) are higher security issue costs associated with higher marginal responses of investment to internal cash, and 2) are the known methods of identifying financially constrained firms sufficient to mimic 
high $\mathrm{C}_{11}$ ? The difficulty in answering these questions lies in the inability to observable financing constraints. Firms that are financially constrained face relatively high capital market frictions that possibly result in undervaluation of planned investment spending (the lemons problem of Akerlof, 1970). Although the security issue is observable, the amount of the issue may be less than planned investment spending. In other words, the shortfall in funds needed for planned investment spending is likely to be supplemented with internal funds.

\subsubsection{Cost of external funds}

Lee, et al. (1996) provide evidence that external funds costs differ by issue type, wherein the per-dollar cost of seasoned equity is roughly twice that for straight debt. Altinkilic and Hansen (2000) confirm this result and also show that differences in costs exist within a specific type of security issue, and these differences can be explained by firm type. More important to the KZ-FHP theory, Altinkilic and Hansen suggest that there exists a family of $U$-shaped average cost curves, with the highest per unit costs associated with comparatively large seasoned equity offerings by firms with relatively high stock price volatility. Altinkilic and Hansen document that the marginal costs of both seasoned equity and bond issues are increasing in the dollar amount of external funds (i.e., $\mathrm{C}_{11}>0$ ). Corresponding to the family of $\mathrm{U}$-shaped average cost curves, Altinkilic and Hansen find a family of marginal cost curves, where smaller firms face steeper marginal costs of external financing. This finding applies to both straight debt and seasoned equity issues, and suggests that different types of firms face different external funds cost structures. 
Important implications of the preceding include: (1) equity issuers face higher issue costs compared to debt issuers, (2) the slope of the marginal cost of equity issues is steeper than that for debt issues, and (3) within a specific type of security offering (seasoned equity or seasoned debt), the slope of the marginal cost is higher for smaller firms. Security issue type combined with firm size is therefore expected to provide a reasonable approximation of security issue cost.

\subsubsection{Predictions}

The KZ-FHP theory indicates a positive relationship between investment and internal funds, or

$\mathrm{H}_{1}$ : Investment increases in internal funds.

Fazzari, et al. (2000) argue that as long as firms are separated in a manner that exposes large differences in $\mathrm{C}_{11}$, firms with higher $\mathrm{C}_{11}$ have higher investment-internal funds sensitivities. In other words, internal funds are more important to planned investment spending for firms facing higher capital market frictions that cause underpricing of the planned project. Based on Lee, et al. (1996) and Altinkilic and Hansen (2000), smaller firms face significantly steeper marginal costs of both seasoned debt and equity offerings, with the $\mathrm{C}_{11}$ for equity exceeding that for debt. If smaller firms face higher capital market frictions compared to larger firms, then small firm investment is expected to be more sensitive to internal funds as the size of the equity issue increases, or 
$\mathrm{H}_{2}$ : Small firms with relatively large equity issues are expected to have higher marginal responses of investment to internal funds compared to large firms with relatively large equity issues.

The last issue to be examined is whether previous methods of identifying financially constrained firms are closely related to the three factors predicted to matter to the investment-internal funds response: firm size, security issue type, and proceeds of the issue. Finding a strong correlation between the firms identified as financially constrained using methods found in the literature and these three cost factors suggests that such methods are sufficient to mimic costs of funds.

\subsection{Research method}

\subsubsection{Measuring security issue cost}

According to the FHP-KZ foundation for sensitivity of investment to internal funds, firms must be separated in a manner that produces large differences in the slope of the marginal costs of external financing. As suggested by Lee, et al., (1996) and Altinkilic and Hanson (2000), debt is a lower cost source of funds compared to equity, the per-unit cost of both debt and equity increase with the dollar amount of the issue, and the slopes of the marginal cost of equity is higher for equity issuers. To adequately separate firm by the cost of the securities issue, firm years are independently sorted into thirds of the distributions of debt issues and stock issues, and the extremes of the distribution are used in the analysis. Four external funds cost categories are created from the sort on stock and debt issues: low stock-low debt issues (LSLD), low stock-high debt 
issues (LSHD), high stock-low debt issues (HSLD), and high stock-high debt issues (HSHD). Security issue costs are predicted to range from lowest to highest in the following order: LSLD, LSHD, HSLD, and HSHD. The use of security issue type as a proxy for security issue cost has the disadvantage of being a noisy signal. However, using the issue type to approximate issue cost allows for the inclusion of a significantly larger number of observations in the sample due to difficulty in observing costs of private placements.

\subsubsection{Measuring firm size}

The size measure used to subdivide the sample is beginning-period total assets. Sample firm years are divided into thirds of the distribution of a size variable. Small firms years are those appearing in the bottom third of the distribution, and large firm years are those appearing in the top third ${ }^{8}$.

\subsubsection{Measuring the investment-internal funds response}

The regression function used to test investment sensitivity to cash flow and cash follows the standard definition found in the literature (e.g., Fazzari, et al., 1988; Kaplan and Zingales, 1997). While prior research typically defines investment as capital expenditures, firms often have other types of discretionary expenditures that require financing. Other types of discretionary expenditures include acquisitions and research and development (R\&D). For tests in this paper, investment (INVEST) is defined as net discretionary expenditures, including capital expenditures and other investments net of

\footnotetext{
${ }^{8}$ Partitioning the sample by firm size is also related to attempts to identify the unobservable financing constraint, specifically Gilchrist and Himmelberg (1995).
} 
(book values of) sales of plant, property, and equipment (Frank and Goyal, 2003), acquisitions, and research and development expense (R\&D). Like capital expenditures, both acquisitions and R\&D are discretionary expenditures and are important to growth in earnings. Prior work in the area of investment-cash flow sensitivity also typically defines internal cash flow as operating cash flows. For this study, the definition of internal cash flow (CASHFLOW) is broadened to include other flows that may be used in financing investment spending (see Frank and Goyal, 2003). Because R\&D expense is included as a discretionary expenditure, it is treated as an asset instead of an accounting expense, and therefore the period's expense is added to back to CASHFLOW. CASH is cash and equivalents at the beginning of the period. Market-to-book assets (MTB) is also defined according to Frank and Goyal (2003). The market-to-book assets ratio is used instead of the ratio of the market value of equity to its book value because asset values are relatively more stable for smaller firms. With these variable definitions, the basic regression function is as follows:

$$
\operatorname{INVEST}_{\mathrm{jt}}=\mathrm{b}_{0}+\mathrm{b}_{1} \mathrm{MTB}_{\mathrm{jt}-1}+\mathrm{b}_{2} \mathrm{CASHFLOW}_{\mathrm{jt}}+\mathrm{b}_{3} \mathrm{CASH}_{\mathrm{jt}-1}+\mathrm{e}_{\mathrm{jt}}
$$

where

INVEST $_{t} \quad$ Net investment in year $\mathrm{t}, \mathrm{INVEST}_{\mathrm{t}}=$ capital expenditures + increase in investments + acquisitions + other use of funds - sale of PPE - sale of investments $+R \& D$ expense

MTB $_{t-1} \quad$ A measure of Tobin's $\mathrm{Q}, \mathrm{MTB}_{\mathrm{t}-1}=($ total assets + market value of common equity - book value of common equity) / total assets

CASHFLOW $_{t} \quad$ Cash flow after taxes, CASHFLOW $_{t}=$ income before extraordinary items + depreciation and amortization + extraordinary items and discontinued operations + deferred taxes + equity in net loss + other funds from 
operations + gain (loss) from sales of PPE and other investments + R\&D expense

$\mathrm{CASH}_{\mathrm{t}-1} \quad$ Cash and equivalents

Period $t$ refers to the end of the fiscal period. INVEST, CASHFLOW, and CASH are scaled by beginning-period total assets.

To estimate the relationship between INVEST and CASHFLOW and INVEST and CASH while jointly considering the role of security issue cost, indicators for security issue cost are interacted with both CASHFLOW and CASH for the LSLD, LSHD, HSLD, and HSHD groups of small and large firm years. This modification to eq. (4a) is as follows (firm year and time period subscripts are omitted):

$$
\begin{gathered}
\text { INVEST }=b_{0}+b_{1} \mathrm{MTB}+\mathrm{b}_{2}{ }^{\mathrm{LSLD}} \mathrm{CF}^{\mathrm{LSLD}}+\mathrm{b}_{2}{ }^{\mathrm{LSHD}} \mathrm{CF}^{\mathrm{LSHD}}+\mathrm{b}_{2}{ }^{\mathrm{HSLD}} \mathrm{CF}^{\mathrm{HSLD}} \\
+\mathrm{b}_{2}{ }^{\mathrm{HSHD}} \mathrm{CF}^{\mathrm{HSHD}}+\mathrm{b}_{3}{ }^{\mathrm{LSLD}} \mathrm{CASH}^{\mathrm{LSLD}}+\mathrm{b}_{3}{ }^{\mathrm{LSHD}} \mathrm{CASH}^{\mathrm{LSHD}}+\mathrm{b}_{3}{ }^{\mathrm{HSLD}} \mathrm{CASH}^{\mathrm{HSLD}} \\
+\mathrm{b}_{3}{ }^{\mathrm{HSHD}} \mathrm{CASH}^{\mathrm{HSHD}}+\mathrm{e}
\end{gathered}
$$

Eq. (4b) is estimated separately for the each size-based subsample (small and large firm years). Following directly from the KZ-FHP propositions discussed above, the one-period optimization problem above implies that the coefficients on CASHFLOW and CASH are positive, or the first hypothesis to be tested $\left(\mathrm{H}_{1}\right)$ is $\mathrm{b}_{2}{ }^{\mathrm{SMALL}}, \mathrm{b}_{2}{ }^{\text {LARGE }}>0$, $\mathrm{b}_{3}{ }^{\text {SMALL }}, \mathrm{b}_{3}{ }^{\text {LARGE }}>0$ for all security issue cost classifications.

The HSLD and HSHD subdivisions of the small firm year sample are expected to represent the highest cost of external funds. If relatively higher capital market frictions result in undervaluation of proposed investment spending of small firms, then small firms facing comparatively high equity issue costs have investment spending that is relatively 
more sensitive to internal cash flow. Alternatively, small firm $b_{2}{ }^{\mathrm{HSLD}}$ and $\mathrm{b}_{2}{ }^{\mathrm{HSHD}}$ are expected to be significantly larger than any of large firm year $b_{2}$.

Given the results in Almeida, et al., (2004), cash is expected to be relatively more important to investment for small firm years with comparatively large equity issues. Small firms that face comparatively high equity issue costs due to higher capital market frictions are expected to have investment spending that is relatively more sensitive to internal cash flow. Alternatively, small firm $b_{3}{ }^{\mathrm{HSLD}}$ and $\mathrm{b}_{3}{ }^{\mathrm{HSHD}}$ are expected to be significantly larger than any of large firm year $b_{3}$.

\subsection{Data and Sample Selection}

Annual data are from the Compustat active and research files from 1982-2001. Only publicly traded (stock ownership codes 0 and 3), U.S.-incorporated firms are included in the sample. Financial firms (SIC 6000-6999) and regulated utilities (SIC 4900-4999) are excluded, as are firms with major mergers (footnote code AB). To be included in the sample, remaining firm years must report the following data items: Statement of Cash Flows format code (item 318), long-term debt issuance (item 111), sale of common and preferred stock (item 108), positive net sales (item 12), income before extraordinary items and taxes (item 123), book value of assets (item 6) at the end of the previous fiscal year, positive common equity (item 60), common shares outstanding at fiscal year end (item 25), and a closing stock price at fiscal year end (item 199). Several cash flow statement observations are set to zero if recorded as missing or combined with other data items, where appropriate (see Appendix for the list of variables). All financial variables in the regression function are scaled by the book value of beginning-period total assets 
(where appropriate). When unscaled financial variables are reported as descriptive measures, these are expressed in real terms ${ }^{9}$.

To control for the influence of IPOs, observations prior to and including the first year in which a nonmissing stock price appears in Compustat are deleted ${ }^{10}$. To control for the inclusion of distressed firms, the sample is restricted to firms with at least $\$ 10$ million in beginning-period total assets. Since the empirical tests are about the relationship between investment spending and cost of external funds, included firm years must have positive discretionary investment expenditures and positive external funds (the sum of debt and equity issues over the period). Total dividends per share is defined as the sum of common cash dividends (item 127) and stock repurchases (item 115) divided by common shares outstanding at year end (item 25). Cash dividends and stock repurchases are set to zero if reported as missing or combined figures. Firm years with negative values of total dividends are deleted. The resulting sample consists of 16,729 firm years from 1982 through 2001.

\subsection{Results}

Table 1 gives descriptive statistics for the sample partitioned by firm size and security issue type. All included firm years have positive investment expenditures and external financing. The partitioning is quite effective in separating firm years by security issue cost. Both small and large firm years that fall into low stock-low debt issue group (LSLD) issue zero debt and virtually zero stock. While relatively low compared to the

\footnotetext{
${ }^{9}$ The average annual Producer Price Index, All Commodities, base year=1982, is used to convert variables into real quantities.

${ }^{10}$ Carpenter and Petersen (2002) report that the first incidence of a non-missing stock price in Compustat indicates the year in which the firm goes public.
} 
other subsamples, the LSLD firm years have positive investment spending that is financed primarily with internal funds. Specifically, the average small firm year spends $12 \%$ of its beginning year total assets, and the average large firm year spends $9 \%$ of its beginning total assets. The small firm beginning cash balance is $21 \%$ of its total assets, and the large firm cash balance is $12 \%$. For both small and large firm years that fall into the LSHD group, both types of firms issue virtually zero stock, and thus security issue costs reflect the cost of debt issues. The average small firm issues $43 \%$ of beginning assets, and large firms issue debt in the amount of $33 \%$ of beginning assets. The beginning cash balance is relatively low for the average small and large firm year, $8 \%$ and $5 \%$ of beginning assets, respectively. Security issue costs for the HSLD groups of small and large firms only reflect the cost of issuing equity; debt issues are zero for both groups. The average small firm year issues equity in the amount of $35 \%$ of beginning assets and holds $35 \%$ of total assets in cash at the beginning of the issue year. The average large firm year issues equity in the amount of $7 \%$ of its beginning assets, but holds $22 \%$ of its assets in cash at the beginning of the period. The final cut of the data is the HSHD group. The average HSHD small firm issues debt and equity securities that total of $86 \%$ of beginning assets, and the average large firm year issues securities in the amount of $54 \%$ of beginning assets.

Table 1 also shows the z-statistics for the difference in means tests between small and large firm years for each of the four financing type subdivisions of the sample. Compared to the average large firm, the average small firm invests more, pays out significantly less in dividends, obtains a greater amount of external funds as a percentage of total assets, and has a higher issue year beginning cash balance. Cash flow is not 
significantly different for large and small firms that issue relatively low amounts of equity. However, cash flow is significantly lower for small firms that issue relatively high amounts of equity. The relatively low cash flow and relatively higher beginning cash balance suggests that on average, cash is relatively more important to the small firm years.

The regression results from estimating eq. (4b) are given in Table 2 for both small and large firm years. Eq. (4b) is estimated separately for the small and large firm years, and any differences in the effects of cash flow and cash on investment spending between the different security issue cost groups are captured by indicators of security issue type interacted with each variable. The coefficient estimates for internal cash flow are positive and statistically significant in every case. With the exception of the LSLD firm years, the coefficient estimates for beginning cash are positive and significant. Recall that the LSLD firm years issue zero debt and virtually zero equity. The significance of CASHFLOW and the insignificance of CASH suggest that LSLD firm years fund investment with cash flow. The general significance of CASHFLOW and CASH are in violation of the prediction of Tobin's Q model, which suggests that the coefficient estimates of any other variable except $Q$ will be statistically insignificant. Note that the coefficient estimates for MTB, the proxy for Q, is positive and statistically significant for both small and large firm years, yet the estimates are economically small (0.04 and 0.01 , respectively). Also note the relatively low regression $\mathrm{R}^{2} \mathrm{~s}$ that indicate that both cash and cash flow are marginal sources of funds for investment purposes.

The four coefficient estimates for cash flow are compared within each small and large group and t-statistics for the differences in coefficients are presented in Panels A and B of 
Table 3. The purpose of the within-group comparisons is to assess whether cash and cash flow are relatively more important as issue costs increase. None of the t-statistics is statistically significant in Panel A, suggesting that cash flow has an equivalent influence on investment for small firm years, regardless of the cost of external funds. This finding is in line with Alti (2003) who suggests that the positive relationship between investment and cash flow is an indicator of investment opportunities not captured by the proxy for Tobin's Q. For large firm years, the t-statistics in Panel B indicate that cash flow is relatively more important to large firm years in which a relatively high amount of debt is issued, regardless of the stock issue. Table 4 shows t-statistics for tests of differences in coefficients for the influence of beginning-period cash on investment spending within each constraint group. One striking pattern is the relative importance of cash for HSHD small and large firm years. For large firms, cash is also relatively more important for the LSHD group. The general conclusion from the within-group comparisons is that the higher the security issue cost, the more important the beginning-period stock of cash is to investment. This result holds for both the small and large firm years.

Tests of the significance of security issue costs to investment-internal funds sensitivity are based on comparing coefficient estimates for cash flow and cash between small and large firm years. Test statistics for difference in coefficient tests between small and large firm years are displayed in Table 5. Beginning with Panel A, investment is generally no less sensitive to cash flow for large firms as it is for small firm years. This result is consistent with Gomes (2001). If investment spending of small firms is more sensitive to internal funds, then the result must be driven by the investment-cash sensitivity. Panel B shows that cash is no more important as a source of funds for small 
LSHD and small HSLD firms than it is for large LSHD firms. Compared to high-stock issuing large firms, cash is relatively more important to investment of either high debt or high stock issuing small firms. The small firm years that fall into the HSHD group are arguably years in which security issue costs are highest. The HSHD small firms have statistically higher investment response to cash compared to LSHD and HSLD large firms. However, cash is equally important to investment for both small and large HSHD firms.

Finding that the beginning stock of cash is relatively more influential to investment for small firms with relatively high security issue costs compared to large firms with relatively low security issue costs supports the theory in Fazzari, et al. (2000). However, there is no general statistical difference in the influence of cash flow on investment between constraint groups. Finding that the coefficient estimate for beginning cash is equally important to HSHD small and large firms raises the issue of the possible correlation between cash and the level of investment, much like that between cash flow and investment in Alti (2003). This issue is investigated next.

\subsubsection{Cash as a source of liquidity or an indicator of investment opportunities}

It is interesting to note that the predictions for the coefficient estimates in eq. (4b) are in violation of Tobin's $\mathrm{Q}$ model. The beginning-period market-to-book assets ratio (MTB) is the proxy used for Q, and the coefficient on MTB is expected to approximate the marginal effect of $Q$ on investment spending. In eq. (4b), Tobin's Q model predicts that $b_{2}=b_{3}=0$ regardless of financing frictions. However, Erickson and Whited (2000) and Alti (2003) argue that Q is a noisy proxy for investment opportunities for small and 
growth firms. Specifically, Alti suggests that a substantial part of Q represents the option value of long-term growth prospects, and is not highly informative of current investment for financially constrained firms. On the other hand, cash flow is informative of project quality, and thus higher cash flow will trigger adjustments to concurrent investment.

Both the KZ-FHP theory and the findings in Alti (2003) suggest a significant positive relationship between investment and cash flow that is relatively more important for financially constrained firms, but for differing reasons. The KZ-FHP theory suggests that cash flow is relevant to investment because of its relatively higher liquidity value for financially constrained firms that face a higher cost wedge between internal and external funds. Alti suggests that cash flow contains information about the investment opportunity set that is not present in the proxy for Q. Similarly, if cash is relatively more important to firms facing higher capital market frictions, then not only should beginning period t cash (the issue period) be relatively more significant to investment for financially constrained firms, but also period $\mathrm{t}+1$ cash should be inversely related to period $\mathrm{t}$ investment.

Since the results from estimating eq. (4b) indicate that cash reserves are relatively more important to small firms facing high issue costs, but cash flow is equally important to small and large firms, only the relationship between current investment and the future cash balance is examined. Specifically, the ending-period cash balance in period $t+1$ is expected to be inversely related to current period investment if cash reserves are built up to cover any shortfall in external financing needed for investment purposes. If cash is relatively more important for high-cost issuers, then this inverse relationship is expected 
to hold only for firms facing relatively higher issue costs (small firms with large equity issues), but not for other firms.

The results from estimating eq. (4b) with four added post-issue year $\mathrm{CASH}_{\mathrm{t}+1}$ terms (one for each issue cost category) are in Table $6^{11}$. All of the CASHFLOW and CASH $\mathrm{CH}_{\mathrm{t}-1}$ coefficient estimates are positive and significant. The $\mathrm{CASH}_{\mathrm{t}+1}$ estimates for the small and large LSLD firm years are significantly negative. For small firms, the LSHD $\mathrm{CASH}_{\mathrm{t}+1}$ estimate is not significant, and the $\mathrm{HSLD} \mathrm{CASH}_{\mathrm{t}+1}$ is positive and significant. The small firm HSHD CASH $\mathrm{H}_{\mathrm{t}+1}$ estimate is negative and weakly significant (t-statistic is 2.08). The $\mathrm{CASH}_{t+1}$ estimates for large firm years are negative and significant, but the HSHD estimate is very weakly significant (t-statistic is 1.79). Most important is the lack of statistical difference between the small and large $\mathrm{HSHD} \mathrm{CASH}_{\mathrm{t}+1}$ estimates $(\mathrm{t}$-statistic for difference in coefficients is 0.15$)$. The results from including the post-issue year cash balance do not support the liquidity explanation for small firms.

Overall, the analysis provides mixed results on the relative importance of internal funds for investment spending by firms likely to face greater capital market frictions. Issue-period cash flow is equally important to small and large firm years regardless of the type of security issue. A difference between the importance of pre-issue period cash reserves emerges most notably for small firm years that issue large amounts of debt and equity. As a test of whether this difference is related to liquidity needs or to investment opportunities not captured by the proxy for Tobins's Q does not support the liquidity explanation. The empirical results are not highly supportive of the theory of Fazzari, et

\footnotetext{
${ }^{11}$ Table 6 results are estimated for 1982-2000 due to the lead year requirement.
} 
al. (2000), and corroborate the findings in Almeida, et al., (2004), Gomes (2001), and Alti (2003), at least for financing constraints approximated by firm size.

\subsection{Do methods of identifying financially constrained firms mimic high capital market frictions?}

The KZ-FHP theory claims that internal funds are relatively more important for investment spending when capital market frictions cause such financially constrained firms to face higher marginal costs of raising external funds. The tests in Section 5 examine if internal funds are relatively more important to firms likely to face higher capital market frictions that somehow limit a firm's ability to fully fund planned investment. The combination of firm size, issue type, and proceeds of the issue is used to approximate issue cost. However, capital market frictions and therefore financing constraints are unobservable. Variables used in prior studies thought to be correlated with the constraint are all based on the notion that financially constrained firms have relatively less freely available funds in the form of cash and cash flow to distribute to shareholders. Two issues are investigated next: first, do these methods of identifying the constraint factor provide enough separation by differences in the slope of the marginal cost of external funds to generate a relatively higher investment-internal funds response for constrained firms, and second, is this response due to differences in liquidity needs or is it a reflection of investment opportunities not captured by the proxy for Tobin's Q.

The analysis also serves as a robustness test for the Section 5 results.

Four separate methods are used to identify financially constrained firms: firm size (e.g., Gilchrist and Himmelberg, 1995), dividend payout (e.g., Fazzari, et al., 1988), a composite measure of funds available for distribution to shareholders (e.g., Kaplan and 
Zingales, 1997), and the existence of a bond rating (e.g., Whited, 1992). Financially constrained firms are labeled "FC", and firms that are not financially constrained (those that face relatively fewer capital market frictions) are denoted "NFC". Each classification method is described below. The FC and NFC firm years are partitioned by security issue type and size of proceeds to compare the results with those in Section 5. The coefficients in eq. (4a) are estimated for each classification method, and the estimated investment sensitivity to cash flow and the beginning stock of cash is compared between FC and NFC firm years. As in Section 5, the post-issue year ending cash balance is added to eq. (4a) to examine the role of cash as a source of liquidity or an indicator of investment opportunities.

\subsubsection{Firm Size}

Beginning period market value of equity serves as an alternative measure of firm size. Sample firm years are divided into thirds of the distribution of a size variable. FC years are those appearing in the bottom third of the distribution, and NFC years are those appearing in the top third. This measure of firm size also serves as a robustness test for the results in Section 5 .

\subsubsection{Dividend Payout}

The common dividend payout ratio based on Fazzari, et al., (1988) is often used as a proxy for the existence of financing constraints. The dividends-based measure used in this study is total dividends per share, which is the sum of common dividends per share 
and share repurchases. Firm years are sorted by the distribution of the dividend payout ratio. The bottom third of the firm years are classified as FC, and the top third as NFC.

\subsubsection{KZ Index}

The method in Kaplan and Zingales (1997), commonly referred to as the KZ index, ranks firm years on the predicted likelihood of changing dividend policy over the fiscal year. In this method, the financing constraint factor is treated as a continuous unobservable variable that can take different states at each point in time, and these states assume a natural ordering. Since the dependent variable is treated as latent, indicators of the firm's dividend policy over fiscal year $t$ are used to describe the constraint factor. The dependent variable takes a value of 0 if the firm increases dividends per share in fiscal year $\mathrm{t}, 1$ if the firm maintains the same dividends per share in fiscal year $\mathrm{t}$, and 2 if the firm decreases dividends per share in fiscal year t. Five financial ratios are used to explain the constraint factor: internal cash flow (CASHFLOW), the beginning period market to book ratio (MTB), total debt, defined as the sum of long term and the current portion of long term debt (DEBT), total dividends (DIV) per share, and cash (CASH). With the exception of MTB and DIV, the explanatory variables are scaled by beginningperiod total assets (TA). The indicators of dividend policy are regressed on the five accounting ratios using an ordered logit specification.

For each firm, the five ratios are calculated at the beginning of the firm's fiscal year $t$ based on accounting and market information from fiscal year $t-1$. The predicted $\mathrm{KZ}_{\mathrm{j}}$ are calculated as: 


$$
\begin{aligned}
& K Z_{j}=\hat{\alpha}_{1} C A S H F L O W / T A+\hat{\alpha}_{2} M T B+\hat{\alpha}_{3} D E B T / T A+\hat{\alpha}_{4} D I V \\
& +\hat{\alpha}_{5} C A S H / T A
\end{aligned}
$$

A firm with higher cash flows, dividend payments, and cash holdings is less likely to be liquidity constrained, and so CASHFLOW, DIV, and CASH are expected to be inversely related to the constraint factor, and positively related to the likelihood of increasing dividends per share. A firm with higher beginning-period debt financing is more likely to be financially constrained over the fiscal period and so DEBT is expected to be positively related to the constraint factor, and inversely related to the likelihood of increasing dividends per share. MTB is expected to be positively related to the constraint factor, and inversely related to the probability of increasing dividends. By construction, $\mathrm{KZ}$ is expected to be larger for firms that face lower financial market frictions.

To form portfolios, the predicted $\mathrm{KZ}_{\mathrm{j}}$ are calculated for the full sample and are then ordered from lowest to highest. Financing constraint portfolios are formed by dividing the ranked firm years into thirds. Firm years with the lowest predicted index values are the most likely to cut dividends over the fiscal year, and thus the bottom third of the firm years in the $\mathrm{KZ}$ distribution are labeled as $\mathrm{FC}$, and the top third of the distribution as NFC.

\subsubsection{Bond Rating}

The non-existence of a bond rating has been used to identify firms as financially constrained. The idea behind this method is that the bond rating represents the market's assessment of a firm's creditworthiness. The method employed here follows Almeida, et 
al., (2004). Financially constrained firms years are those that never had a bond rating over the entire sample period and have positive beginning period debt.

\subsubsection{Results}

The results of repeating the main analysis for the four alternative methods of ranking FC and NFC firms are displayed in Tables 7 and 8 . The regression results from estimating eq. (4b) are not reported. Only the t-statistics for testing differences in coefficients for cash flow and cash between FC and NFC samples are reported in Tables 7 and 8 , respectively. The results for the investment-internal cash flow sensitivity for market cap sorted samples in Table 7 are similar to those for the assets-sorted samples in Panel A of Table 5. Most notably, cash flow is relatively more important to investment for NFC high debt issuing firms compared to FC HSLD and LSHD firms. The bondrating sorted sample gives a similar result, but other clear patterns of the importance of cash flow to a particular subset of firm years are not apparent. In Table 8, the patterns of significant differences between FC and NFC firm years agree with those in Table 5 in all cases, consistent with the theory of Fazzari, et al. (1988) that constrained firms facing higher costs of external financing have investment spending that is relatively more sensitive to the beginning-period stock of cash. Further, cash is equally as important to investment for both HSHD FC and NFC firm years, a result that suggests that investment-cash sensitivity is an increasing function of investment spending.

To formally test the idea that cash is an indicator of investment opportunities not captured by the proxy for Tobin's Q, the results from estimating eq. (4b) modified for the ending-period $\mathrm{t}+1$ cash balances are reported for the dividend and $\mathrm{KZ}$ index sorted 
samples in Tables 9 and 10, respectively. For the dividend-sorted FC firms, $\mathrm{CASH}_{\mathrm{t}+1}$ is inversely related to period t investment only for the LSLD firm years. The HSLD $\mathrm{CASH}_{\mathrm{t}+1}$ coefficient estimate is again positive and significant, but the $\mathrm{CASH}_{\mathrm{t}+1}$ estimates for LSHD and HSHD firm years are not significant. The $\mathrm{CASH}_{\mathrm{t}+1}$ estimates for NFC firm years are negative and significant, except for the HSLD firm years, which is negative but not significant. The results for the $\mathrm{KZ}$ index sorted samples in Table 10 provide a slightly stronger, but not a clearly convincing case for the relative importance of cash to firms with higher financing frictions. For the FC firms years, the LSLD and LSHD CASH $\mathrm{t}_{\mathrm{t}+1}$ estimates are negative and significant. The HSLD estimate is again positive and significant, and the HSDS estimate is not significant. The only negative and significant $\mathrm{CASH}_{\mathrm{t}+1}$ estimate for NFC firm years is related to the LSLD group. The other $\mathrm{NFC} \mathrm{CASH}_{\mathrm{t}+1}$ estimates are not significant.

\subsection{Conclusion}

This study tests and finds support for the notion that financially constrained firms have investment spending that is relatively more sensitive to internal funds that is attributable to differences in the cost of external funds, as put forward by Fazzari, Hubbard, and Petersen $(1988,2000)$. Firm years are separated by the cost of external financing, and it is the highest-cost financially constrained firm years that have the highest investment-internal funds sensitivity. However, this sensitivity is not necessarily driven by internal cash flow, but rather by the beginning stock of cash. Cash flow is positively correlated with investment spending, but is generally no more relevant to financially constrained firms, a finding that agrees with Gomes (2001) and Alti (2003). 
This result is robust to alternative approximations of the constraint factor. The fullsample results in this study agree with those in Almeida, et al. (2004) in that cash financially constrained firms have investment spending that is relatively more cash sensitive than non-financially constrained firms. However, future period cash balances are not on the whole inversely related to the issue year beginning cash balance for financially constrained firms, a finding that does not support the liquidity explanation for the relative importance of cash. These findings raise the issue of whether cash is a substitute for external financing or rather the stock of cash is built up in anticipation of increased demand for working capital as a result of investment spending, a topic left to future research. 


\section{References}

Akerlof, George A., 1970, The Market for "Lemons": Quality, Uncertainty, and the Market Mechanism, Quarterly Journal of Economics 84, 488-500.

Almeida, Heitor, Murillo Campello, and Michael S. Weisbach, 2004, The Cash Flow Sensitivity of Cash, Journal of Finance 59:4 (August), 1777-1804.

Alti, Aydogan, 2003, How Sensitive Is Investment to Cash Flow When Financing Is Frictionless? Journal of Finance 58:2 (April), 707-22.

Altinkilic, Oya, and Robert S. Hanson, 2000, Are There Economies of Scale in Underwriting Fees? Evidence of Rising External Financing Costs, Review of Financial Studies 13:1 (Spring), 191-218.

Cleary, Sean, 1999, The Relationship between Firm Investment and Financial Status, Journal of Finance 54:2 (April), 673-92.

Carpenter, Robert E., and Bruce C. Petersen, 2002, Capital Market Imperfections, HighTech Investment, and New Equity Financing, Economic Journal 112:4 (February), 54-72.

Cummins, Jason G., Kevin A Hassett, and Stephen D. Oliner, 1999, Investment Behavior, Observable Expectations, and Internal Funds, Board of Governors of the Federal Reserve System, Finance and Economics Discussion Series: 99/27 (May).

Fazzari, Steven M., R. Glenn Hubbard, and Bruce C. Petersen, 1988, Financing Constraints and Corporate Investment, Brookings Papers on Economic Activity n1, 14195.

Fazzari, Steven M., R. Glenn Hubbard, and Bruce C. Petersen, 2000, Investment-Cash Flow Sensitivities Are Useful: A Comment on Kaplan and Zingales, Quarterly Journal of Economics 115:2 (May), 141-95.

Gilchrist, Simon, and Charles P. Himmelberg, 1995, Evidence on the Role of Cash Flow for Investment, Journal of Monetary Economics 36, 541-72.

Gomes, Joao F., 2001, Financing Investment, American Economic Review 91:5 (December), 1263-85.

Kaplan, Steven N., and Luigi Zingales, 1997, Do Financing Constraints Explain Why Investment Is Correlated With Cash Flow?, Quarterly Journal of Economics, 112:1, 695705.

Kaplan, Steven N., and Luigi Zingales, 2000, Investment-Cash Flow Sensitivities Are Not Valid Measures of Financing Constraints, Quarterly Journal of Economics 115:2 (May), 707-12. 
Lee, Inmoo, Scott Lochhead, Jay Ritter, and Quanshui Zhao, 1996, The Costs of Raising Capital, Journal of Financial Research 19:1 (Spring), 59-74.

Whited, Toni, 1992, Debt, Liquidity Constraints, and Corporate Investment: Evidence from Panel Data, Journal of Finance 47: (), 425-60. 


\section{Appendix: Construction of variables}

All accounting data are from the Compustat annual active and research files. A (*) by the data item indicates that it is set to zero if reported as combined with another item or is missing.

\section{Net investment (INVEST)}

Format codes 1, 2, 3: Net investments = capital expenditures (item 128)* + increase in investments (item 113)* + acquisitions (item 129)* - uses of funds, other (item 219)* sale of plant, property, and equipment (item 107)* - sale of investments (item 109)* + R\&D expense (item 218)*

Format code 7: Net investments = capital expenditures (item 128)* + increase in investments (item 113)* + acquisitions (item 129)* - sale of plant, property, and equipment (item 107)* - sale of investments (item 109)* - short term investments, change (item 309)* - investing activities, other (item 310)* + R\&D expense (item 218)*

\section{Internal cash flow (CASHFLOW)}

Format codes 1, 2, 3: Cash flow after interest and taxes $=$ income before taxes (item $123)+$ extraordinary items and discontinued operations (item 124)* + depreciation and amortization (item 125)* + deferred taxes (item 126)* + equity in net loss (item 106)* + gain (loss)* from sales of PPE and other investments (item 213)* + other funds from operations (item 217)* + sources of funds, other (item 218)* + R\&D expense (item 46)*

Format code 7: Cash flow after interest and taxes $=$ income before taxes (item 123) + extraordinary items and discontinued operations (item 124)* + depreciation and amortization (item 125)* + deferred taxes (item 126)* + equity in net loss (item 106)* + gain (loss)* from sales of PPE and other investments (item 213)* + other funds from operations (item 217)* + exchange rate effect (item 314 )* + R\&D expense (item 46)*

\section{Market-to-book assets (MTB)}

MTB $=1+[$ (closing price per share of common stock at fiscal year end (item 199) multiplied by the number of common shares outstanding at fiscal year end (item 25) common equity, total (item 60)]/total assets (item 6) 


\section{Table 2.1: Descriptive Statistics for Size-Sorted Samples}

The sample period is from 1982-2001. Included firm years have positive discretionary expenditures and external financing. Small (large) firm years are the lower (upper) third of the distribution of beginning period total assets in any given year. Market-to-book is the beginning-period market value of assets divided by beginning assets. For Statement of Cash Flow format codes 1,2,3[7], investment $=$ items $128+113+129-219-107-109+46[128+113+129-107-309-310+46]$. For SCF format codes 1,2,3[7], internal cash flow $=$ items $123+124+125+126+106+213+217+218+46[123+124+125+126+106+213$ $+217+314+46]$. Cash is cash and equivalents (item). Debt issues are long-term debt issuance (item 111) and stock issues are sales of common and preferred stock (item 108). Total assets are beginning-period in 1982 dollars and all other variables are scaled by the beginning-period book value of assets, where appropriate.

Panel A: Low stock, low debt issues

\begin{tabular}{lccccc}
\hline & \multicolumn{2}{c}{ Small } & \multicolumn{2}{c}{$\begin{array}{c}\text { Large } \\
\text { N=945 }\end{array}$} & \multicolumn{2}{c}{$\begin{array}{c}\text { Mean small }- \\
\text { Mean large } \\
\text { Mean }\end{array}$} & Std. Error & Mean & Std. Error & z-statistic \\
\hline Total assets & 26.62 & 11.67 & $1,050.06$ & $2,661.37$ & -9.21 \\
Market value equity & 33.91 & 39.00 & $1,104.00$ & $5,665.82$ & -4.52 \\
Investment & 0.12 & 0.16 & 0.09 & 0.12 & 3.57 \\
Common dividends & 0.01 & 0.02 & 0.02 & 0.02 & -9.76 \\
Total dividends & 0.10 & 0.40 & 0.69 & 1.60 & -8.61 \\
Internal cash flow & 0.12 & 0.22 & 0.12 & 0.11 & -0.13 \\
Market-to-book & 1.49 & 0.98 & 1.44 & 0.88 & 1.08 \\
Debt issues & 0.00 & 0.00 & 0.00 & 0.00 & N/A \\
Stock issues & 0.00 & 0.00 & 0.00 & 0.00 & 2.53 \\
Cash & 0.21 & 0.21 & 0.12 & 0.14 & 9.68
\end{tabular}

Panel B: Low stock, high debt issues

\begin{tabular}{lccccc}
\hline & \multicolumn{2}{c}{ Small } & \multicolumn{2}{c}{$\begin{array}{c}\text { Large } \\
\text { N=2,223 }\end{array}$} & \multicolumn{2}{c}{ N=275 } & $\begin{array}{c}\text { Mean small - } \\
\text { Mean large } \\
\text { Mean }\end{array}$ & Std. Error & Mean & Std. Error & z-statistic \\
\hline Total assets & 27.07 & 11.53 & $2,862.31$ & $13,774.43$ & -9.82 \\
Market value equity & 25.40 & 28.62 & $2,713.11$ & $16,427.25$ & -7.80 \\
Investment & 0.23 & 0.37 & 0.18 & 0.22 & 4.79 \\
Common dividends & 0.01 & 0.03 & 0.02 & 0.03 & -9.07 \\
Total dividends & 0.39 & 5.72 & 5.15 & 162.70 & -1.40 \\
Internal cash flow & 0.12 & 0.18 & 0.12 & 0.10 & 0.40 \\
Market-to-book & 1.39 & 0.82 & 1.39 & 0.68 & 0.21 \\
Debt issues & 0.43 & 0.61 & 0.33 & 0.43 & 6.57 \\
Stock issues & 0.00 & 0.00 & 0.00 & 0.00 & -6.95 \\
Cash & 0.08 & 0.12 & 0.05 & 0.07 & 10.63
\end{tabular}


Table 2.1 (continued)

Panel C: High stock, low debt issues

\begin{tabular}{lccccc}
\hline & \multicolumn{2}{c}{ Small } & \multicolumn{2}{c}{ Large } & Mean small - \\
& Mean & Std. Error & Mean & Std. Error & $\begin{array}{c}\text { Mean large } \\
\text { z-statistic }\end{array}$ \\
\hline Total assets & 26.19 & 11.27 & $1,339.73$ & $3,305.66$ & -14.93 \\
Market value equity & 97.98 & 127.25 & $5,472.80$ & $25,427.10$ & -7.94 \\
Investment & 0.37 & 0.51 & 0.22 & 0.18 & 15.84 \\
Common dividends & 0.01 & 0.03 & 0.02 & 0.04 & -10.28 \\
Total dividends & 0.13 & 2.36 & 6.88 & 232.54 & -1.09 \\
Internal cash flow & 0.19 & 0.29 & 0.25 & 0.17 & -8.31 \\
Market-to-book & 3.44 & 3.42 & 3.38 & 4.18 & 0.46 \\
Debt issues & 0.00 & 0.00 & 0.00 & 0.00 & N/A \\
Stock issues & 0.35 & 0.72 & 0.07 & 0.11 & 23.23 \\
Cash & 0.35 & 0.27 & 0.22 & 0.20 & 18.12
\end{tabular}

Panel D: High stock, high debt issues

\begin{tabular}{|c|c|c|c|c|c|}
\hline & \multicolumn{2}{|c|}{$\begin{array}{c}\text { Small } \\
\mathrm{N}=1,799\end{array}$} & \multicolumn{2}{|c|}{$\begin{array}{c}\text { Large } \\
\mathrm{N}=1,585\end{array}$} & \multirow{2}{*}{$\begin{array}{c}\text { Mean small - } \\
\text { Mean large } \\
\text { Z-statistic }\end{array}$} \\
\hline & Mean & Std. Error & Mean & Std. Error & \\
\hline Total assets & 25.61 & 11.39 & $2,118.62$ & $7,127.49$ & -11.69 \\
\hline Market value equity & 57.79 & 78.59 & $3,126.60$ & $10,423.21$ & -11.72 \\
\hline Investment & 0.54 & 0.95 & 0.36 & 0.38 & 7.55 \\
\hline Common dividends & 0.00 & 0.02 & 0.01 & 0.03 & -9.55 \\
\hline Total dividends & 0.48 & 10.86 & 4.50 & 83.39 & -1.91 \\
\hline Internal cash flow & 0.14 & 0.29 & 0.17 & 0.14 & -4.14 \\
\hline Market-to-book & 2.49 & 2.23 & 2.15 & 3.29 & 3.52 \\
\hline Debt issues & 0.55 & 1.25 & 0.43 & 0.51 & 3.59 \\
\hline Stock issues & 0.31 & 0.55 & 0.11 & 0.19 & 14.05 \\
\hline Cash & 0.15 & 0.19 & 0.09 & 0.12 & 11.22 \\
\hline
\end{tabular}


Table 2.2: Investment Response to Cash Flow and Cash for Size-Sorted Samples The sample period is from 1982-2001. Included firm years have positive discretionary expenditures and external financing. Small (large) firm years are the lower (upper) third of the distribution of beginning period total assets in any given year. Firm years are independently sorted into thirds of the distributions of equity and debt issues and are classified as low stock-low debt (LSLD), low stock-high debt (LSHD), high stock-low debt (HSLD), or high stock-high debt (HSHD) if the firm years falls into the bottom (low) or top (high) of the two distributions. Indicator variables are used to isolate the marginal effects of cash flow (CF) and cash (CASH) on investment spending for each security issue type. Market-to-book (MTB) is the beginning-period market value of assets divided by beginning assets. Standard errors are corrected according to White's procedure, and asymptotic t-statistics are in parentheses.

\begin{tabular}{|c|c|c|}
\hline & Small & Large \\
\hline Intercept & $\begin{array}{c}0.07 \\
(3.51)\end{array}$ & $\begin{array}{c}0.05 \\
(6.88)\end{array}$ \\
\hline MTB & $\begin{array}{c}0.04 \\
(6.04)\end{array}$ & $\begin{array}{c}0.01 \\
(4.44)\end{array}$ \\
\hline $\mathbf{C F}^{\text {LSLD }}$ & $\begin{array}{c}0.39 \\
(2.41)\end{array}$ & $\begin{array}{c}0.49 \\
(2.64)\end{array}$ \\
\hline $\mathbf{C F}^{\text {LSHD }}$ & $\begin{array}{c}0.38 \\
(3.77)\end{array}$ & $\begin{array}{c}0.94 \\
(10.70)\end{array}$ \\
\hline $\mathbf{C F}^{\mathrm{HSLD}}$ & $\begin{array}{c}0.35 \\
(7.67)\end{array}$ & $\begin{array}{c}0.48 \\
(14.38)\end{array}$ \\
\hline $\mathrm{CF}^{\mathrm{HSHD}}$ & $\begin{array}{c}0.95 \\
(2.95)\end{array}$ & $\begin{array}{c}1.02 \\
(11.95)\end{array}$ \\
\hline CASH $^{\text {LSLD }}$ & $\begin{array}{c}-0.03 \\
(-0.68)\end{array}$ & $\begin{array}{c}-0.04 \\
(-0.84)\end{array}$ \\
\hline CASH $^{\text {LSHD }}$ & $\begin{array}{c}0.55 \\
(5.88)\end{array}$ & $\begin{array}{c}0.43 \\
(5.62)\end{array}$ \\
\hline CASH $^{\text {HSLD }}$ & $\begin{array}{c}0.36 \\
(7.42)\end{array}$ & $\begin{array}{c}0.15 \\
(5.46)\end{array}$ \\
\hline CASH $^{\mathrm{HSHD}}$ & $\begin{array}{c}1.32 \\
(7.74)\end{array}$ & $\begin{array}{c}0.89 \\
(8.09)\end{array}$ \\
\hline $\mathrm{R}^{2}$ & 0.19 & 0.30 \\
\hline
\end{tabular}




\section{Table 2.3: Within-Group Comparisons of Coefficient Estimates for Cash Flow}

The sample period is from 1982-2001. Included firm years have positive discretionary expenditures and external financing. Small (large) firm years are the lower (upper) third of the distribution of beginning period total assets in any given year. Firm years are independently sorted into thirds of the distributions of equity and debt issues and are classified as low stock-low debt (LSLD), low stock-high debt (LSHD), high stock-low debt (HSLD), or high stock-high debt (HSHD) if the firm year falls into the bottom (low) or top (high) of the two distributions. Indicator variables are used to isolate the marginal effects of cash flow (CF) on investment spending for each security issue type. In Panels A and B, coefficient estimates for cash flow (CF) in Table 2 are compared within the small and large groups (row estimate compared to column estimate), and t-statistics for the difference in coefficients are in the tables.

Panel A: Small firms

\begin{tabular}{lcccc}
\hline & LSLD & LSHD & HSLD & HSHD \\
\hline LSLD & -- & & & \\
LSHD & -0.04 & -- & & \\
HSLD & -0.21 & -0.22 & -- & -- \\
HSHD & 1.16 & 1.36 & 1.65 &
\end{tabular}

Panel B: Large firms

\begin{tabular}{lcccc}
\hline & LSLD & LSHD & HSLD & HSHD \\
\hline LSLD & -- & & & \\
LSHD & 1.65 & -- & & \\
HSLD & -0.03 & -3.77 & -- & - \\
HSHD & 1.97 & 0.48 & 4.54 & -
\end{tabular}




\section{Table 2.4: Within-Group Comparisons of Coefficient Estimates for Cash}

The sample period is from 1982-2001. Included firm years have positive discretionary expenditures and external financing. Small (large) firm years are the lower (upper) third of the distribution of beginning period total assets in any given year. Firm years are independently sorted into thirds of the distributions of equity and debt issues and are classified as low stock-low debt (LSLD), low stock-high debt (LSHD), high stock-low debt (HSLD), or high stock-high debt (HSHD) if the firm years fall into the bottom (low) or top (high) of the two distributions. Indicator variables are used to isolate the marginal effects of cash (CASH) on investment spending for each security issue type. In Panels A and B, coefficient estimates for cash (CASH) in Table 2 are compared within the small and large groups (row estimate compared to column estimate), and t-statistics for the difference in coefficients are in the tables.

Panel A: Small firms

\begin{tabular}{lcccc}
\hline & LSLD & LSHD & HSLD & HSHD \\
\hline LSLD & -- & & & \\
LSHD & 4.05 & -- & & \\
HSLD & 3.98 & -1.31 & -- & - \\
HSHD & 6.11 & 2.91 & 4.35 & -
\end{tabular}

Panel B: Large firms

\begin{tabular}{lcccc}
\hline & LSLD & LSHD & HSLD & HSHD \\
\hline LSLD & -- & & & \\
LSHD & 3.68 & -- & & \\
HSLD & 2.40 & -2.74 & -- & - \\
HSHD & 5.77 & 2.51 & 5.46 & -
\end{tabular}




\section{Table 2.5: Between-Group Comparisons of Coefficient Estimates}

The sample period is from 1982-2001. Included firm years have positive discretionary expenditures and external financing. Small (large) firm years are the lower (upper) third of the distribution of beginning period total assets in any given year. Firm years are independently sorted into thirds of the distributions of equity and debt issues and are classified as low stock-low debt (LSLD), low stock-high debt (LSHD), high stock-low debt (HSLD), or high stock-high debt (HSHD) if the firm years fall into the bottom (low) or top (high) of the two distributions. Indicator variables are used to isolate the marginal effects of cash flow (CF) and cash $(\mathrm{CASH})$ on investment spending for each security issue type. In Panels A and B, coefficient estimates for cash flow (CF) and cash (CASH) in Table 2 are compared between the small and large groups (row estimate compared to column estimate), and t-statistics for the difference in coefficients are in the tables.

Panel A: Cash Flow

\begin{tabular}{llcccc}
\hline \multirow{5}{*}{ Small } & \multicolumn{5}{c}{ Large } \\
LSLD & LSHD & HSLD & HSHD \\
\cline { 2 - 6 } & LSLD & -0.29 & -2.21 & -0.48 & -2.57 \\
& LSHD & -0.39 & -2.99 & -0.78 & -3.47 \\
& HSLD & -0.62 & -4.47 & -1.73 & -5.18 \\
& HSHD & 0.91 & 0.03 & 1.32 & -0.17
\end{tabular}

Panel B: Beginning Cash

\begin{tabular}{clcccc}
\hline \multirow{3}{*}{ Small } & \multicolumn{5}{c}{ Large } \\
LSLD & LSHD & HSLD & HSHD \\
\cline { 2 - 6 } & LSLD & 0.09 & -3.63 & -2.31 & -5.74 \\
& LSHD & 4.09 & 0.75 & 3.38 & -1.66 \\
& HSLD & 4.04 & -0.49 & 2.90 & -3.31 \\
& HSHD & 6.13 & 3.64 & 5.96 & 1.53
\end{tabular}




\section{Table 2.6: Investment Response to Cash Flow, Issue Year Cash, and Post-issue}

\section{Year Cash for Size-Sorted Samples}

The sample period is from 1982-2000. Included firm years have positive discretionary expenditures and external financing. Small (large) firm years are the lower (upper) third of the distribution of beginning period total assets in any given year. Firm years are independently sorted into thirds of the distributions of equity and debt issues and are classified as low stock-low debt (LSLD), low stock-high debt (LSHD), high stock-low debt (HSLD), or high stock-high debt (HSHD) if the firm years falls into the bottom (low) or top (high) of the two distributions. Indicator variables are used to isolate the marginal effects of cash flow (CF), beginning-period issue year cash balance (CASH(t-1)), and the ending-period post-issue year cash balance in year $\mathrm{t}+1(\mathrm{CASH}(\mathrm{t}+1))$ on investment spending for each security issue type. Market-to-book (MTB) is the beginning-period market value of assets divided by beginning assets. Standard errors are corrected according to White's procedure, and asymptotic t-statistics are in parentheses.

$$
\operatorname{INVEST}_{j \mathrm{t}}=\mathrm{b}_{0}+\mathrm{b}_{1} \mathrm{MTB}_{\mathrm{jt}-1}+\mathrm{b}_{2} \mathrm{CF}_{\mathrm{jt}}+\mathrm{b}_{3} \mathrm{CASH}_{\mathrm{jt}-1}+\mathrm{b}_{4} \mathrm{CASH}_{\mathrm{jt}+1}+\mathrm{e}_{\mathrm{jt}}
$$

\begin{tabular}{|c|c|c|}
\hline & Small & Large \\
\hline Intercept & $\begin{array}{c}0.07 \\
(3.02)\end{array}$ & $\begin{array}{c}0.06 \\
(6.73)\end{array}$ \\
\hline МTB & $\begin{array}{c}0.04 \\
(5.49)\end{array}$ & $\begin{array}{c}0.01 \\
(4.06)\end{array}$ \\
\hline $\mathbf{C F}^{\text {LSLD }}$ & $\begin{array}{c}0.41 \\
(2.83)\end{array}$ & $\begin{array}{c}0.52 \\
(2.85)\end{array}$ \\
\hline $\mathbf{C F}^{\mathrm{LSHD}}$ & $\begin{array}{c}0.37 \\
(3.20)\end{array}$ & $\begin{array}{c}1.02 \\
(10.65)\end{array}$ \\
\hline $\mathbf{C F}^{\mathrm{HSLD}}$ & $\begin{array}{c}0.32 \\
(5.93)\end{array}$ & $\begin{array}{c}0.50 \\
(13.26)\end{array}$ \\
\hline $\mathbf{C F}^{\mathrm{HSHD}}$ & $\begin{array}{c}0.97 \\
(2.70)\end{array}$ & $\begin{array}{c}1.10 \\
(10.87)\end{array}$ \\
\hline $\operatorname{CASH}^{\mathrm{LSLD}}(\mathrm{t}-1)$ & $\begin{array}{c}0.14 \\
(2.99)\end{array}$ & $\begin{array}{c}0.18 \\
(2.35)\end{array}$ \\
\hline $\operatorname{CASH}^{\mathrm{LSHD}}(\mathrm{t}-1)$ & $\begin{array}{c}0.63 \\
(5.16)\end{array}$ & $\begin{array}{c}0.72 \\
(6.59)\end{array}$ \\
\hline $\operatorname{CASH}^{\mathrm{HSLD}}(\mathrm{t}-1)$ & $\begin{array}{c}0.22 \\
(3.86)\end{array}$ & $\begin{array}{c}0.27 \\
(6.08)\end{array}$ \\
\hline $\operatorname{CASH}^{\mathrm{HSHD}}(\mathrm{t}-1)$ & $\begin{array}{c}1.57 \\
(6.57)\end{array}$ & $\begin{array}{c}1.13 \\
(6.55)\end{array}$ \\
\hline $\operatorname{CASH}^{\operatorname{LSLD}}(\mathrm{t}+\mathbf{1})$ & $\begin{array}{c}-0.25 \\
(-4.24)\end{array}$ & $\begin{array}{c}-0.30 \\
(-2.15)\end{array}$ \\
\hline $\operatorname{CASH}^{\mathrm{LSHD}}(\mathrm{t}+1)$ & $\begin{array}{c}-0.07 \\
(-0.32)\end{array}$ & $\begin{array}{c}-0.56 \\
(-5.92)\end{array}$ \\
\hline $\operatorname{CASH}^{\mathrm{HSLD}}(\mathrm{t}+\mathbf{1})$ & $\begin{array}{c}0.20 \\
(3.32)\end{array}$ & $\begin{array}{c}-0.15 \\
(-3.40)\end{array}$ \\
\hline $\operatorname{CASH}^{\mathrm{HSHD}}(\mathrm{t}+1)$ & $\begin{array}{c}-0.36 \\
(-2.08)\end{array}$ & $\begin{array}{c}-0.42 \\
(-1.79)\end{array}$ \\
\hline $\mathrm{R}^{2}$ & 0.20 & 0.32 \\
\hline
\end{tabular}


Table 2.7: Robustness to Alternative Proxies for the Constraint Factor, BetweenGroup Comparisons of Coefficient Estimates for Cash Flow

The sample period is from 1982-2001. Included firm years have positive discretionary expenditures and external financing. In Panels A through C, a firm year in any given year is classified as financially constrained (FC) or not financially constrained (NFC) if the observation falls into the lower (upper) third of the distribution of the KZ index (Panel A), beginning-period total assets (Panel B), or beginning-period market-to-book equity (Panel C). In Panel D, a firm year is classified as FC if the firm does not have a bond rating over the entire sample period, and NFC otherwise. Firm years are independently sorted into thirds of the distributions of equity and debt issues and are classified as low stock-low debt (LSLD), low stock-high debt (LSHD), high stock-low debt (HSLD), or high stock-high debt (HSHD) if the firm year falls into the bottom (low) or top (high) of the two distributions. In each panel, coefficient estimates for CASHFLOW (not shown) are compared between the FC and NFC groups (row estimate compared to column estimate), and t-statistics for the difference in coefficients are in the tables.

Panel A: Size (Market Value of Equity)

\begin{tabular}{|c|c|c|c|c|c|}
\hline & & $\mathrm{C}$ & & & \\
\hline & & LSLD & LSHD & HSLD & HSHD \\
\hline FC & LSLD & -1.17 & -3.48 & -1.89 & -3.72 \\
\hline & LSHD & 0.20 & -1.34 & 0.77 & -1.83 \\
\hline & HSLD & -0.38 & -2.59 & -0.25 & -3.00 \\
\hline & HSHD & 1.58 & 1.03 & 2.24 & 0.63 \\
\hline
\end{tabular}

Panel B: Dividend Payout

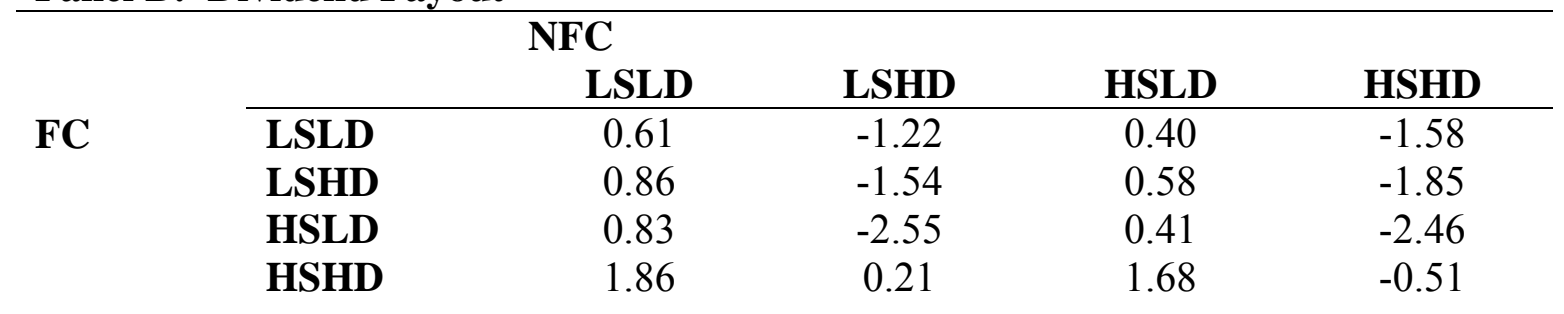

Panel C: KZ Index

\begin{tabular}{llcccc}
\hline \multirow{3}{*}{ FC } & \multicolumn{5}{c}{ NFC } \\
\cline { 2 - 6 } & LSLD & LSHD & HSLD & HSHD \\
\cline { 2 - 6 } & LSHD & 2.20 & -0.02 & 1.47 & -0.78 \\
& HSLD & 2.76 & 0.01 & 1.84 & -0.85 \\
& HSHD & 3.30 & -0.43 & 1.91 & -1.55 \\
& 2.50 & 1.08 & 2.11 & 0.65
\end{tabular}

Panel D: Bond Rating

\begin{tabular}{|c|c|c|c|c|c|}
\hline \multirow{2}{*}{\multicolumn{6}{|c|}{$\begin{array}{ll}\text { NFC } \\
\text { LSLD }\end{array}$}} \\
\hline & & LSLD & LSHD & HSLD & HSHD \\
\hline \multirow[t]{4}{*}{ FC } & LSLD & -2.03 & -3.47 & -2.35 & -5.16 \\
\hline & LSHD & -0.08 & -1.29 & 0.56 & -3.19 \\
\hline & HSLD & -0.82 & -2.41 & -0.37 & -4.51 \\
\hline & HSHD & 0.63 & 0.01 & 1.06 & -1.21 \\
\hline
\end{tabular}


Table 2.8: Robustness to Alternative Proxies for the Constraint Factor, BetweenGroup Comparisons of Coefficient Estimates for Cash

The sample period is from 1982-2001. Included firm years have positive discretionary expenditures and external financing. In Panels A through C, a firm year in any given year is classified as financially constrained (FC) or not financially constrained (NFC) if the observation falls into the lower (upper) third of the distribution of the KZ index (Panel A), beginning-period total assets (Panel B), or beginning-period market-to-book equity (Panel C). In Panel D, a firm year is classified as FC if the firm does not have a bond rating over the entire sample period, and NFC otherwise. Firm years are independently sorted into thirds of the distributions of equity and debt issues and are classified as low stock-low debt (LSLD), low stock-high debt (LSHD), high stock-low debt (HSLD), or high stock-high debt (HSHD) if the firm year falls into the bottom (low) or top (high) of the two distributions. In each panel, coefficient estimates for CASH (not shown) are compared between the FC and NFC groups (row estimate compared to column estimate), and t-statistics for the difference in coefficients are in the tables.

Panel A: Size (Market Value of Equity)

\begin{tabular}{|c|c|c|c|c|c|}
\hline & & $\mathrm{C}$ & & & \\
\hline & & LSLD & LSHD & HSLD & HSHD \\
\hline FC & LSLD & 1.10 & -2.62 & -2.48 & -4.89 \\
\hline & LSHD & 3.24 & -0.07 & 1.36 & -2.01 \\
\hline & HSLD & 2.47 & -1.31 & -0.26 & -3.52 \\
\hline & HSHD & 3.71 & 2.04 & 3.02 & 0.98 \\
\hline
\end{tabular}

Panel B: Dividend Payout

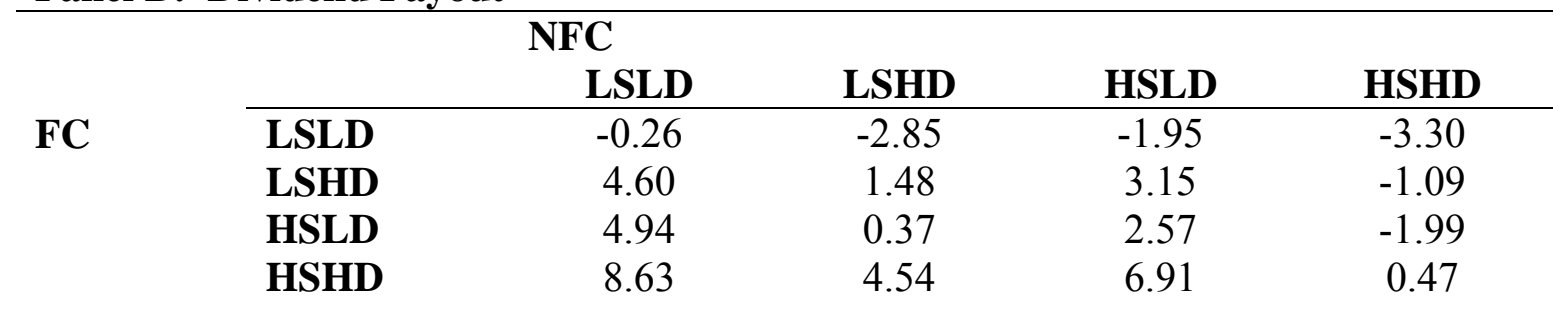

Panel C: KZ Index

\begin{tabular}{llcccc}
\hline \multirow{3}{*}{ FC } & \multicolumn{5}{c}{ NFC } \\
\cline { 2 - 6 } & LSLD & LSHD & HSLD & HSHD \\
\cline { 2 - 6 } & LSLD & 2.42 & -1.84 & 0.58 & -3.49 \\
& HSLD & 5.06 & 0.63 & 3.41 & -1.19 \\
& HSHD & 6.26 & 0.19 & 3.79 & -1.89 \\
& & 8.84 & 3.69 & 7.09 & 1.56
\end{tabular}

Panel D: Bond Rating

\begin{tabular}{|c|c|c|c|c|c|}
\hline \multicolumn{6}{|c|}{ NFC } \\
\hline & & LSLD & LSHD & HSLD & HSHD \\
\hline \multirow[t]{4}{*}{ FC } & LSLD & 0.72 & -3.50 & -3.07 & -5.91 \\
\hline & LSHD & 4.22 & 0.79 & 2.17 & -1.92 \\
\hline & HSLD & 4.89 & 0.00 & 1.79 & -3.25 \\
\hline & HSHD & 6.76 & 3.88 & 5.41 & 1.20 \\
\hline
\end{tabular}




\section{Table 2.9: Investment Response to Cash Flow, Issue Year Cash, and Post-issue} Year Cash for Dividend-Sorted Samples

The sample period is from 1982-2000. Included firm years have positive discretionary expenditures and external financing. FC (NFC) firm years are the lower (upper) third of the distribution of beginning period total dividends per share in any given year. Firm years are independently sorted into thirds of the

distributions of equity and debt issues and are classified as low stock-low debt (LSLD), low stock-high debt (LSHD), high stock-low debt (HSLD), or high stock-high debt (HSHD) if the firm years falls into the bottom (low) or top (high) of the two distributions. Indicator variables are used to isolate the marginal effects of cash flow (CF), beginning-period issue year cash balance (CASH(t-1)), and the ending-period post-issue year cash balance in year $\mathrm{t}+1(\mathrm{CASH}(\mathrm{t}+1))$ on investment spending for each security issue type. Market-to-book (MTB) is the beginning-period market value of assets divided by beginning assets.

Standard errors are corrected according to White's procedure, and asymptotic t-statistics are in parentheses.

$$
\operatorname{INVEST}_{\mathrm{jt}}=\mathrm{b}_{0}+\mathrm{b}_{1} \mathrm{MTB}_{\mathrm{jt}-1}+\mathrm{b}_{2} \mathrm{CF}_{\mathrm{jt}}+\mathrm{b}_{3} \mathrm{CASH}_{\mathrm{jt}-1}+\mathrm{b}_{4} \mathrm{CASH}_{\mathrm{jt}+1}+\mathrm{e}_{\mathrm{jt}}
$$

\begin{tabular}{|c|c|c|}
\hline & FC & NFC \\
\hline Intercept & $\begin{array}{c}0.11 \\
(6.74)\end{array}$ & $\begin{array}{c}0.05 \\
(2.59)\end{array}$ \\
\hline MTB & $\begin{array}{c}0.03 \\
(5.67)\end{array}$ & $\begin{array}{c}0.02 \\
(2.05)\end{array}$ \\
\hline $\mathbf{C F}^{\text {LSLD }}$ & $\begin{array}{c}0.41 \\
(2.64)\end{array}$ & $\begin{array}{c}0.24 \\
(2.62)\end{array}$ \\
\hline $\mathbf{C F}^{\mathrm{LSHD}}$ & $\begin{array}{c}0.40 \\
(3.20)\end{array}$ & $\begin{array}{c}0.77 \\
(6.90)\end{array}$ \\
\hline $\mathbf{C F}^{\mathrm{HSLD}}$ & $\begin{array}{c}0.33 \\
(6.62)\end{array}$ & $\begin{array}{c}0.29 \\
(2.85)\end{array}$ \\
\hline $\mathbf{C F}^{\mathrm{HSHD}}$ & $\begin{array}{c}0.89 \\
(3.60)\end{array}$ & $\begin{array}{c}1.07 \\
(3.90)\end{array}$ \\
\hline $\operatorname{CASH}^{\text {LSLD }}(t-1)$ & $\begin{array}{c}0.10 \\
(2.37)\end{array}$ & $\begin{array}{c}0.08 \\
(1.75)\end{array}$ \\
\hline $\operatorname{CASH}^{\mathrm{LSHD}}(\mathrm{t}-1)$ & $\begin{array}{c}0.73 \\
(5.81)\end{array}$ & $\begin{array}{c}0.48 \\
(6.33)\end{array}$ \\
\hline $\operatorname{CASH}^{\mathrm{HSLD}}(\mathrm{t}-1)$ & $\begin{array}{c}0.23 \\
(4.37)\end{array}$ & $\begin{array}{c}0.17 \\
(2.17)\end{array}$ \\
\hline $\operatorname{CASH}^{\mathrm{HSHD}}(\mathrm{t}-1)$ & $\begin{array}{c}1.18 \\
(8.95)\end{array}$ & $\begin{array}{c}1.33 \\
(3.95)\end{array}$ \\
\hline $\operatorname{CASH}^{\operatorname{LSLD}}(\mathrm{t}+\mathbf{1})$ & $\begin{array}{l}-0.25 \\
(-4.20)\end{array}$ & $\begin{array}{c}-0.17 \\
(-4.13)\end{array}$ \\
\hline $\operatorname{CASH}^{\mathrm{LSHD}}(\mathrm{t}+\mathbf{1})$ & $\begin{array}{c}-0.27 \\
(-1.40)\end{array}$ & $\begin{array}{c}-0.39 \\
(-3.35)\end{array}$ \\
\hline $\operatorname{CASH}^{\mathrm{HSLD}}(\mathrm{t}+1)$ & $\begin{array}{c}0.16 \\
(2.83)\end{array}$ & $\begin{array}{c}-0.09 \\
(-0.89)\end{array}$ \\
\hline $\operatorname{CASH}^{\mathrm{HSHD}}(\mathrm{t}+\mathbf{1})$ & $\begin{array}{c}-0.22 \\
(-1.49)\end{array}$ & $\begin{array}{c}-0.86 \\
(-2.47)\end{array}$ \\
\hline $\mathrm{R}^{2}$ & 0.23 & 0.25 \\
\hline
\end{tabular}


Table 2.10: Investment Response to Cash Flow, Issue Year Cash, and Post-issue Year Cash for Samples Sorted on the KZ Index

The sample period is from 1982-2000. Included firm years have positive discretionary expenditures and external financing. FC (NFC) firm years are the lower (upper) third of the distribution of the KZ index in any given year. Firm years are independently sorted into thirds of the distributions of equity and debt issues and are classified as low stock-low debt (LSLD), low stock-high debt (LSHD), high stock-low debt (HSLD), or high stock-high debt (HSHD) if the firm years falls into the bottom (low) or top (high) of the two distributions. Indicator variables are used to isolate the marginal effects of cash flow (CF), beginningperiod issue year cash balance (CASH(t-1)), and the ending-period post-issue year cash balance in year $\mathrm{t}+1$ $(\mathrm{CASH}(\mathrm{t}+1))$ on investment spending for each security issue type. Market-to-book (MTB) is the beginning-period market value of assets divided by beginning assets. Standard errors are corrected according to White's procedure, and asymptotic t-statistics are in parentheses.

$$
\operatorname{INVEST}_{\mathrm{jt}}=\mathrm{b}_{0}+\mathrm{b}_{1} \mathrm{MTB}_{\mathrm{jt}-1}+\mathrm{b}_{2} \mathrm{CF}_{\mathrm{jt}}+\mathrm{b}_{3} \mathrm{CASH}_{\mathrm{jt}-1}+\mathrm{b}_{4} \mathrm{CASH}_{\mathrm{jt}+1}+\mathrm{e}_{\mathrm{jt}}
$$

\begin{tabular}{|c|c|c|}
\hline & FC & NFC \\
\hline Intercept & $\begin{array}{c}0.09 \\
(3.62)\end{array}$ & $\begin{array}{c}0.08 \\
(3.80)\end{array}$ \\
\hline MTB & $\begin{array}{c}0.02 \\
(5.41)\end{array}$ & $\begin{array}{c}0.04 \\
(2.71)\end{array}$ \\
\hline $\mathbf{C F}^{\text {LSLD }}$ & $\begin{array}{c}0.50 \\
(4.33)\end{array}$ & $\begin{array}{c}0.09 \\
(1.40)\end{array}$ \\
\hline $\mathbf{C F}^{\mathrm{LSHD}}$ & $\begin{array}{c}0.54 \\
(4.97)\end{array}$ & $\begin{array}{c}0.51 \\
(2.39)\end{array}$ \\
\hline $\mathbf{C F}^{\mathrm{HSLD}}$ & $\begin{array}{c}0.41 \\
(7.12)\end{array}$ & $\begin{array}{c}0.20 \\
(2.61)\end{array}$ \\
\hline $\mathbf{C F}^{\mathrm{HSHD}}$ & $\begin{array}{c}1.11 \\
(3.03)\end{array}$ & $\begin{array}{c}0.72 \\
(4.23)\end{array}$ \\
\hline $\operatorname{CASH}^{\text {LSLD }}(t-1)$ & $\begin{array}{c}0.20 \\
(3.66)\end{array}$ & $\begin{array}{c}-0.10 \\
(-2.47)\end{array}$ \\
\hline $\operatorname{CASH}^{\mathrm{LSHD}}(\mathrm{t}-1)$ & $\begin{array}{c}0.74 \\
(6.44)\end{array}$ & $\begin{array}{c}0.37 \\
(2.95)\end{array}$ \\
\hline $\operatorname{CASH}^{\mathrm{HSLD}}(\mathrm{t}-1)$ & $\begin{array}{c}0.25 \\
(3.75)\end{array}$ & $\begin{array}{c}-0.18 \\
(-1.89)\end{array}$ \\
\hline $\operatorname{CASH}^{\mathrm{HSHD}}(\mathrm{t}-1)$ & $\begin{array}{c}1.37 \\
(7.26)\end{array}$ & $\begin{array}{c}0.77 \\
(3.80)\end{array}$ \\
\hline $\mathrm{CASH}^{\mathrm{LSLD}}(\mathbf{t}+\mathbf{1})$ & $\begin{array}{c}-0.30 \\
(-4.68)\end{array}$ & $\begin{array}{c}-0.13 \\
(-4.71)\end{array}$ \\
\hline $\operatorname{CASH}^{\mathrm{LSHD}}(\mathbf{t}+\mathbf{1})$ & $\begin{array}{c}-0.50 \\
(-4.36)\end{array}$ & $\begin{array}{c}-0.08 \\
(-0.21)\end{array}$ \\
\hline $\operatorname{CASH}^{\mathrm{HSLD}}(\mathrm{t}+\mathbf{1})$ & $\begin{array}{c}0.16 \\
(2.36)\end{array}$ & $\begin{array}{c}0.14 \\
(1.49)\end{array}$ \\
\hline $\mathrm{CASH}^{\mathrm{HSHD}}(\mathrm{t}+\mathbf{1})$ & $\begin{array}{c}-0.33 \\
(-1.87)\end{array}$ & $\begin{array}{c}0.08 \\
(0.35)\end{array}$ \\
\hline $\mathrm{R}^{2}$ & 0.23 & 0.12 \\
\hline
\end{tabular}


Chapter 3

\title{
The Effect of Competitive Structure on the Relationship between Leverage and Profitability
}

\begin{abstract}
This study investigates the influence of the speed of reversion in profitability in explaining observed differences in the responses of leverage to profitability across industry competitive environments. If the leverage-profitability relationship is driven by the speed of reversion, then any influence of industry concentration on this relationship is expected to disappear. When industry concentration is approximated by calculating the Herfindahl-Hirschman Index by 4-digit SIC from the Compustat universe, the results suggest that the speed of reversion in profitability positively influences leverage, but is not important to the inverse relationship between leverage and profitability. Leverage also increases in the level of industry concentration, but higher industry concentration results in a greater inverse response of leverage to profitability. This result is robust to alternative methods of estimating the speed of reversion in profitability and alternative definitions of leverage. However, when industry concentration is measured by the U.S. Census Bureau Herfindahl-Hirschman Index for manufacturing firms, the empirical results generally support the prediction that differences in the leverage-profitability relationship between competitive and concentrated industries is related to differences in the speed of reversion in profitability.
\end{abstract}




\subsection{Introduction}

The relationship between leverage and profitability has been studied extensively in support for theories of capital structure. Recent attention has been given to the influence of competitive environment on capital structure. For example, MacKay and Phillips (2005) find that leverage responds differently to profitability for firms in concentrated industries compared to competitive industries, and comment that differences in the persistence of profitability may contribute to the differences in the relationship between leverage and profitability when firms are grouped by industry concentration.

Empirically, profitability of firms in concentrated industries differs from that for firms in more competitive industries in terms of level, persistence, and volatility. MacKay and Phillips (2005) find that firms in concentrated industries have relatively higher profits. Further, higher profit levels are attributable to industry concentration (Delorme, et al., 2003). In addition to higher levels of profits, there is evidence that firms in concentrated industries behave differently in preserving profit margins compared to competitive industries. Domowitz, Hubbard, and Petersen (1988) find that markups are countercyclical in concentrated durable goods industries. For non-durable goods sectors, markups are relatively more procyclical in concentrated industries than in competitive industries. Lev (1983) finds that the relationship between barriers to entry and autocorrelation in annual earnings is positive and significant. Hou and Robinson (2006) find that firms in concentrated industries have less variable profits due to lower overall product innovation compared to firms facing higher competition.

The theoretical influence of mean reversion in profitability on the leverageprofitability relationship has been addressed in Raymar (1991), Leland (1994), and 
Sarkar and Zapatero (2003), with varying predictions. In Raymar's model, firms optimally recapitalize at the end of each period, leading to a positive relationship between leverage and profitability. Leland does not model the earnings process as mean reverting, and in turn, finds that the leverage ratio is invariant to changes in profitability. The model in Sarkar and Zapatero generates an inverse relationship between leverage and profitability that is attributable to mean reversion in profitability. In this model, optimal long-term debt is tied to long-term expected profitability. Since periodic changes in profitability revert to the long-run expectation, long-term debt is relatively insensitive to changes in current profits. The inverse relationship between leverage and profitability works through the effect of current profit on equity ${ }^{12}$.

The main contribution of this study is the investigation of whether the speed of reversion in profitability can explain the observed differences in the responses of leverage to profitability across industry competitive environments. The predictions in Sarkar and Zapatero (2003) motivate the expected differences in reactions of leverage to profitability for firms in competitive versus concentrated industries. Profitability is decomposed into the long-run mean, the speed of reversion to the long-run mean, and volatility. Industry concentration is expected to be related to, but not sufficient for the speed of reversion in profitability. Therefore, the speed of reversion is expected to dominate any influence of industry concentration on the leverage-profitability relationship. In other words, if the

\footnotetext{
${ }^{12}$ Sarkar and Zapatero test their model's predictions by first estimating the speed of mean reversion, longrun mean and volatility of profits, eliminating firms which do not have statistically significant speed of mean reversion parameter estimates, and then by examining the relationship between leverage and the estimates of the time-series properties of profitability in a sample of 146 remaining firms. Sarkar and Zapatero find that the variation in leverage is driven by the long-run mean, the speed of mean reversion, and the volatility of profitability, among other factors.
} 
leverage-profitability relationship is driven by the speed of reversion, then any influence of industry concentration on this relationship is expected to disappear.

When industry concentration is approximated by calculating the HerfindahlHirschman Index by 4-digit SIC from the Compustat universe, the results suggest that the speed of reversion in profitability positively influences leverage, but is not important to the inverse relationship between leverage and profitability. Leverage also increases in the level of industry concentration, but higher industry concentration results in a greater inverse response of leverage to profitability. This result is robust to alternative methods of estimating the speed of reversion in profitability and alternative definitions of leverage. However, when industry concentration is measured by the U.S. Census Bureau Herfindahl-Hirschman Index for manufacturing firms, the empirical results generally support the prediction that differences in the leverage-profitability relationship between competitive and concentrated industries is related to differences in the speed of reversion in profitability.

A basic version of the model in Sarkar and Zapatero (2003) is described in Section 2, with emphasis on the model's predictions about the influence of the speed of mean reversion in profitability on the leverage-profitability relationship. The procedures used to estimate the two key variables, the degree of industry concentration and the speed of reversion in profitability, are discussed in Section 3. The regression function used to test for the effects of these two variables on the leverage-profitability relationship is also described in this section. The sample selection is described in Section 4, and the results are presented and discussed in Section 5. Section 6 examines whether the results are 
sensitive to estimates of the speed of reversion in profitability, the definition of leverage, and the method of identifying industry concentration. Section 7 concludes.

\subsection{Predictions}

Sarkar and Zapatero (2003) (hereafter SZ in this section) construct a static tradeoff model that modifies that in Raymar (1991), and incorporates the model in Leland (1994). In the SZ model, the firm consists of a single, infinitely lived project which generates a net cash flow or earnings (EBIT plus depreciation) steam of $\$ \mathrm{x}_{\mathrm{t} .}$. The stream of earnings $x_{t}$ follows a mean reverting stochastic process from Bhattacharya (1978):

$$
d x=\kappa(\theta-x) d t+\sigma x d z
$$

where $\kappa$ is the speed of mean reversion, $\theta$ is the long-run mean to which $\mathrm{x}$ reverts, $\sigma$ is the volatility of earnings, and dz is the movement of a standard Brownian Motion process $^{13}$.

Without considering the terms of the debt contract, eq. (1) rules out negative earnings, i.e., the project has a positive value at all times (Raymar, 1991). However, the firm is also assumed to have a constant level of debt until bankruptcy (Leland, 1994) on which the firm issues a perpetual coupon of $\$ C$ per unit of time. Therefore, earnings net of the coupon payment may be negative. Default occurs when $\mathrm{x}$ falls to a critical value, $\mathrm{x}_{\mathrm{L}}$, at which time the value of equity falls to zero and bondholders assume control of the

\footnotetext{
${ }^{13}$ Eq. (1) is the continuous time version of Raymar's (1991) mean reversion process with the exception of the treatment of earnings volatility, $\sigma$. In Raymar's model, $\sigma$ is constant. The short-run variance of cash flows is constant, but the long-run variance is inversely proportional to the mean reversion in earnings in
} 
firm after incurring a bankruptcy cost. Otherwise, for $\mathrm{x}$ above its critical value, default is an endogenous decision by equity holders (Leland, 1994). As long as equity has some value, equity holders can decide to keep the firm running by issuing additional equity rather than default whenever $\mathrm{x}<\mathrm{C}$.

With these and other assumptions relevant to the static trade-off model, SZ derive the unlevered firm value, or the value of the project assets, as a function of permanent and transitory components, as in Raymar (1991). The results are as follows: 1) the transitory component is decreasing in the speed of mean reversion ( $\kappa)$, and 2) the permanent component is increasing in $\kappa$. Firm value (total assets) inherits mean reversion from its cash flow process. The volatility of firm value is smaller than cash flow volatility because mean reversion in cash flows mitigates part of the volatility in firm value. In absence of mean reverting cash flows, the volatilities of firm value and cash flows are equal. For mean reverting cash flows, the higher the speed of mean reversion, the greater is the reduction in project risk.

The value of the levered firm (FV) is modeled as project value plus the tax benefits of debt less the associated bankruptcy costs. The value of equity $(\mathrm{Eq})$ is the difference between total firm value and the value of debt (D),

$$
\mathrm{Eq}(\mathrm{x})=\mathrm{FV}(\mathrm{x})-\mathrm{D}(\mathrm{x})
$$

Equity is a function of the default level of earnings (default trigger), $\mathrm{x}_{\mathrm{L}}$, which is chosen optimally by equity holders to maximize the value of equity. Equity holders have a menu

Raymar's model, implying that in the long run, firms with higher mean reverting earnings will have more stable earnings. 
of default triggers from which to choose. Each default trigger has an associated coupon, where higher default triggers are associated with higher coupon levels due to the increased risk of default. The default trigger is also increasing in the speed of mean reversion of earnings ( $\kappa)$. A higher $\kappa$ reduces the volatility of firm value, and therefore a higher $\kappa$ leads to a higher $x_{L}$. The optimal default trigger determines optimal debt and equity levels, and therefore optimal debt and equity are both increasing in $\kappa$ and decreasing in project risk.

The SZ model predicts that the speed of reversion in current earnings will determine the strength of the reaction of leverage to changes in profitability. By assumption, the coupon level is constant and set to the long term mean earnings $(\theta)$ in the SZ model, where a higher $\kappa$ is associated with a higher coupon. The inverse relationship between leverage and earnings occurs through the effect of current earnings on equity. From eq. (1), a higher $\kappa$ increases the change in periodic earnings, everything else held constant. When current earnings rise, equity rises by a greater amount when $\kappa$ is relatively higher. For a constant coupon, firms with higher $\kappa$ are expected to have leverage ratios that fall by a greater percentage in response to a change in current period profitability. In other words, the speed of reversion in profitability drives the inverse relationship between leverage and profitability. A higher speed of reversion in profitability is predicted to strengthen the inverse relationship between leverage and profitability, or the response of leverage to profitability is conditional on the speed of reversion in profitability.

From the preceding discussion, the SZ model decomposes profitability into three components of current profitability: the speed of reversion in periodic earnings ( $\kappa)$, long run mean profitability $(\theta)$, and the volatility of periodic earnings $(\sigma)$. Leverage is 
determined by $\kappa, \theta, \sigma$, and other variables related to the static trade-off theory (the marginal tax rate, interest rates, and distress risk). Because the components of profitability $(\kappa, \theta, \sigma)$ are thought to differ by industry concentration, the model proposed by Sarkar and Zapatero (2003) may aid in explaining the observed differences in the leverage-profitability relationship between competitive and concentrated industries.

Lev (1983) and Domowitz, Hubbard, and Petersen (1988) suggest that the speed of reversion in profitability is comparatively slower for firms operating in concentrated industries. These observations suggest a degree of causality between industry concentration and the length of time needed to recover from shocks to profitability. By definition, firms in concentrated industries face fewer competitors due to high barriers to entry. A positive shock to profitability may allow firms in concentrated industries to sustain profits above the long run mean for a longer duration than in competitive industries. However, individual firms operating in concentrated industries may have relatively fast reversion in profitability depending on the nature of the shock to profitability. For example, if one firm enjoys above normal current profitability due to a successful product innovation, this innovation may be quickly copied by its competitors, resulting in a loss in market share and/or market saturation over time. A second probable influence on the speed of reversion in profitability is the cyclicality of the product market. Therefore, industry concentration is expected to be a determinant of, but not sufficient for the speed of reversion in profitability. Denoting industry concentration as $\mathrm{H}$, the expected relationship between the speed of reversion and $\mathrm{H}$ is

$$
\mathrm{H}_{1}: \quad \kappa=f(\mathrm{H}, \text { other factors }), \quad \frac{\partial \kappa}{\partial H}<0 .
$$


The SZ model predicts that the speed of reversion in profitability $(\kappa)$ is expected to be positively related to leverage due to its risk-reducing feature, or

$$
\mathrm{H}_{2}: \quad \frac{\partial L E V}{\partial \kappa}>0
$$

The main contribution of the SZ model is the prediction about the cause of the inverse relationship between leverage and profitability. When current profitability is decomposed into its various components $(\kappa, \theta$, and $\sigma)$, the speed of reversion in profitability is predicted to be the main driver of the inverse relationship between leverage and current profitability, or

$$
\mathrm{H}_{3}: \quad \frac{d(d L E V / d x)}{d \kappa}<0
$$

Since industry concentration is expected to be related to, but not sufficient for the speed of reversion in profitability, then the speed of reversion is expected to dominate any influence of industry concentration on the leverage-profitability relationship. This prediction stated in hypothesis form as:

$$
\mathrm{H}_{4}: \quad \frac{d(d L E V / d x)}{d H}=0
$$


In the SZ model, leverage increases in long-run mean profitability $(\theta)$ and decreases in earnings volatility $(\sigma)$, but the effect of $\sigma$ on leverage is weaker with a higher $\kappa$. Firms in concentrated industries have higher profitability on average (e.g., Delorme, et al., 2003; MacKay and Phillips, 2005). Hou and Robinson (2006) suggest that firms in concentrated industries have lower cash flow volatility due to relatively less product innovation. If the degree of industry concentration approximates both $\theta$ and $\sigma$, then leverage is expected to increase in industry concentration, or

$$
\mathrm{H}_{5}: \quad \frac{\partial L E V}{\partial H}>0 .
$$

To summarize, theory and observed relationships suggest that the speed of reversion in profitability is sufficient to explain why leverage-profitability relationships differ between industry competitive structures. The level of competition is expected to weakly represent the speed of reversion, and therefore should be dominated by the speed of reversion in the leverage-profitability relationship. The level of competition is also expected to represent the level of long-run profitability as well as earnings volatility, and is therefore expected to have an independent influence on leverage.

\subsection{Empirical method}

Tests of the above hypotheses require measurement of two experimental variables, the degree of industry concentration and the speed of reversion in profitability. The methods for estimating the two experimental variables are discussed in the first two 
subsections. The description of the model used to estimate the hypothesized relationships between leverage and profitability follows.

\subsubsection{Estimating industry concentration}

The U.S. Census Bureau constructs the Herfindahl-Hirschman Index (HHI) by 4digit SIC code for manufacturing firms every five years beginning in 1992. While the U.S. Census Bureau HHI is constructed using sales for the 50 largest firms in an industry, these data only include manufacturing firms and do not indicate industry concentration prior to 1992. To overcome the limitations associated with the U.S. Census Bureau HHI, the degree of industry concentration is constructed by using all firms in the Compustat universe with positive sales. The HHI is calculated by 4-digit SIC code for each year in the sample, then each $\mathrm{HHI}$ is scaled by 10,000 to express the number in percentage terms.

The primary advantages of creating the $\mathrm{HHI}$ are the inclusion of a broader sample of industries as well as annual variation in the $\mathrm{HHI}$ dating to the beginning of the sample period, which is 1982. Constructing the HHI with Compustat data has the disadvantage of excluding privately held firms and other firms that are not included in the database over the sample period. Therefore, the constructed HHI is likely to be a noisy approximation of the degree of industry concentration.

According to U.S. Department of Justice and Federal Trade Commission 1997 guidelines, a firm with an industry $\mathrm{HHI}$ of less than 1,000 is classified as belonging to an unconcentrated industry, a moderately concentrated industry for an HHI between 1,000 and 1,800 , and a concentrated industry if the HHI exceeds 1,800 . These classifications are used in the analysis. 


\subsubsection{Estimating the components of profitability}

The mean reversion parameter $(\kappa)$, long run mean profitability $(\theta)$, and earnings variability $(\sigma)$ are estimated for each firm using the method of Sarkar and Zapatero (2003), in which the percentage change in current profitability $\left(E_{t}\right)$ is regressed on a constant and the inverse of last-period's profitability, or

$$
\left(\mathrm{E}_{\mathrm{t}} / \mathrm{E}_{\mathrm{t}-1}\right)-1=\mathrm{a}_{0}+\mathrm{a}_{1} 1 / \mathrm{E}_{\mathrm{t}-1}+\mathrm{u}_{\mathrm{t}}
$$

The intercept $\left(\mathrm{a}_{0}\right)$ is equivalent to $-\kappa$, the (negative of the) speed of mean reversion from eq. (1), $\theta$ is calculated as $-a_{1} / a_{0}$, and $\sigma$ is estimated by the standard deviation of the residuals. Profitability (E) is defined as annual earnings before interest, taxes, and depreciation (EBITDA) divided by total assets. The time series used to estimate the parameters is from 1983-2000, and included firms have a 19-year survivor requirement (one lag year is needed). Only firms with intercept estimates from eq. (2) that are less than or equal to zero ${ }^{14}$ are retained in the sample. For empirical purposes, the estimated speed of reversion in profitability is "K", long run mean profitability is THETA, and earnings volatility is SIGMA.

$\mathrm{K}$ is expected to be a function of, but not fully determined by the degree of industry concentration. The Pearson correlation coefficient for $\mathrm{K}$ and $\mathrm{H}$ is calculated to test this hypothesis $\left(\mathrm{H}_{1}\right)$. If $\mathrm{K}$ is a function of the degree of industry concentration, then

\footnotetext{
${ }^{14}$ Sarkar and Zapatero (2003) keep firms with estimates of the intercept that are negative and statistically significant at the $5 \%$ level to ensure that the sample contains firms that exhibit mean reverting earnings. This restriction is relaxed to allow for the inclusion of firms with acyclical earnings.
} 
the correlation coefficient for $\mathrm{K}$ and $\mathrm{H}$ is expected to be significantly negative, indicating that lower speeds of reversion in profitability are associated with higher degrees of industry concentration.

\subsubsection{Estimating the response of leverage to profitability}

The third hypothesis $\left(\mathrm{H}_{3}\right)$ states that the strength of the inverse relationship between leverage and profitability increases with the speed of reversion in profitability. This interaction is an implication of the model in Sarkar and Zapatero (2003). If the speed of reversion in profit is the main driver of the inverse relationship between leverage and profitability, then the speed of reversion is expected to dominate industry concentration in the leverage-profitability relationship $\left(\mathrm{H}_{4}\right)$. However, industry concentration is expected to independently influence leverage as a proxy for long-run profitability and earnings volatility $\left(\mathrm{H}_{5}\right)$.

The following regression function is used to examine whether the speed of reversion is the primary reason for the inverse relationship between leverage and profitability:

$$
\begin{aligned}
\mathrm{LEV}=\mathrm{b}_{0} & +\mathrm{b}_{1} \mathrm{E}+\mathrm{b}_{2} \mathrm{~K}+\mathrm{b}_{3} \text { THETA }+\mathrm{b}_{4} \mathrm{SIGMA}+\mathrm{b}_{5} \mathrm{H}+\mathrm{b}_{6} \mathrm{EK}+\mathrm{b}_{7} \text { EH }+\mathrm{b}_{8} \mathrm{KH} \\
& +\mathrm{b}_{9} \mathrm{DEP}+\mathrm{b}_{10} \mathrm{RD}+\mathrm{b}_{11} \mathrm{SIZE}+\mathrm{b}_{12} \mathrm{MTB}+\mathrm{u}
\end{aligned}
$$

All variables in eq. (3) are current period (t). LEV is long term debt divided by the book value of common equity. The first three variables in eq. (3) - E, K, and $\mathrm{H}$ - are lower order terms that support the estimation of EK and EH. EK is the response of leverage to 
profitability conditional on the speed of reversion in profitability, and EH is the response of leverage to profitability conditional on the degree of industry concentration. $\mathrm{KH}$ is included to support the two-way interaction, but is not predicted to influence leverage in any specific way.

Profitability (E) is defined as EBITDA divided by total assets and is expected to be inversely related to LEV if profitability is not fully described by its estimated components (K, THETA, and SIGMA); otherwise, E is expected to be insignificant. A positive relationship between $\mathrm{LEV}$ and $\mathrm{K}$ is expected due to its risk reducing feature. The empirical relationship between LEV and $\mathrm{H}$ depends on whether the level of industry concentration is more strongly associated with long-run profitability or cash flow variability. If $\mathrm{H}$ is a proxy for long-run profitability, then a positive relationship is expected between LEV and $\mathrm{H}$. H may also proxy for earnings risk, which is generally expected to reduce leverage.

Leverage is expected to be significantly inversely related to EK, the interaction between profitability and the speed of reversion in profitability, supporting the hypothesis that the inverse relationship between leverage and profitability is stronger for higher $\mathrm{K}$. The relationship between LEV and EH is expected to be insignificant if the influence of $\mathrm{K}$ dominates that of $\mathrm{H}$ in the leverage-profitability relationship, or that $\mathrm{K}$ is sufficient for $\mathrm{H}$ in explaining the observed differences in the leverage-profitability relationship between competitive and more concentrated industries.

Six additional variables are included to control for factors thought to affect long term debt levels across firms, including the estimates of long run average profitability (THETA) and the volatility of earnings (SIGMA). The controls for long-run profit and 
volatility of current profits are included to better isolate the influence of $\mathrm{E}$ and $\mathrm{K}$ on long term debt. Otherwise, $\mathrm{K}$ serves as a weak proxy for long-run profit and volatility, which is a confounding influence on long-term debt. DEP and RD represent nondebt tax shields, thought to be important to the trade-off theory. SIZE represents access to credit markets, and MTB may indicate the demand for credit. SIZE and MTB also serve as proxies for volatility of current profitability. The estimation of both THETA and SIGMA is described in Section 3.2. LEV is expected to be positively related to THETA and inversely related to SIGMA. The calculations and predicted relationships between LEV and the remaining control variables are described below.

DEP denotes a nondebt tax shield in the form of depreciation expense. DeAngelo and Masulis (1980) suggest that nontax debt shields substitute for the interest deduction associated with debt, citing examples such as depreciation and depletion expense and income tax credits. Bradley, Jarrell, and Kim (1984) test the response of optimal leverage to DEP, defined as the sum of depreciation expense and income tax credits, and observe a significant positive relationship, counter to prediction. Fama and French (2002) drop investment tax credits from the DEP definition, and find that book leverage varies inversely with DEP, as predicted. Adopting the Fama-French definition, DEP is measured as depreciation expense divided by total assets. If depreciation expense is a substitute for long-term debt, then LTD is expected to vary inversely with the level of DEP.

DeAngelo and Masulis (1980) also suggest that certain types of investments such as R\&D and advertising expense may serve as nondebt tax shields because of their $100 \%$ deductibility in a given year. Bradley, Jarrell, and Kim (1984) test and find support for 
this prediction. Fama and French (2002) find an inverse relationship between book leverage and $R \& D$ expense, but point out that the explanation for the inverse relationship is ambiguous because $\mathrm{R} \& \mathrm{D}$ expense could also serve as an indicator of expected investment. Because R\&D has been found to be empirically relevant to optimal debt, this item (scaled by total assets) is included in eq. (3) and is denoted as RD to avoid any omitted variable problems. The predicted relationship between LEV and RD is inverse.

SIZE, defined as the natural log of total assets, is included to control for access to debt markets and other risk factors, and is expected to vary directly with LEV. MTB is the market-to-book ratio, defined as the ratio of the market value of common equity to its book value, and is included as an indicator of the firm's growth prospects. Higher growth firms may tend to rely more heavily on external financing, which may lead to a positive relationship between MTB and LEV. On the other hand, MTB may also be correlated with the risk of financial distress, which tends to reduce debt levels.

Considering these possibly confounding interpretations of MTB, the relationship between LEV and MTB is a priori ambiguous.

The conditional relationship between leverage and profitability is calculated using coefficient estimates for $\mathrm{E}, \mathrm{EK}$, and $\mathrm{EH}$, evaluated at plus/minus one standard deviation of the sample mean of $\mathrm{K}$ and $\mathrm{H}$. Four conditional marginal responses result: $\mathrm{K}$ low and $\mathrm{K}$ high (KL, KH), $\mathrm{H}$ low and $\mathrm{H}$ high (HL, $\mathrm{HH})$. The four conditional marginal responses are summarized as follows:

$$
\hat{b}_{K L}=\left.\frac{\partial L E V}{\partial E}\right|_{\bar{K}-\sigma_{K}}=\hat{b}_{1}+\hat{b}_{6}\left(\bar{K}-\sigma_{K}\right)
$$




$$
\begin{gathered}
\hat{b}_{K H}=\left.\frac{\partial L E V}{\partial E}\right|_{\bar{K}+\sigma_{K}}=\hat{b}_{1}+\hat{b}_{6}\left(\bar{K}+\sigma_{K}\right) \\
\hat{b}_{H L}=\left.\frac{\partial L E V}{\partial E}\right|_{\bar{H}-\sigma_{H}}=\hat{b}_{1}+\hat{b}_{7}\left(\bar{H}-\sigma_{H}\right) \\
\hat{b}_{H H}=\left.\frac{\partial L E V}{\partial E}\right|_{\bar{H}+\sigma_{H}}=\hat{b}_{1}+\hat{b}_{7}\left(\bar{H}+\sigma_{H}\right)
\end{gathered}
$$

The estimate of $b_{\mathrm{KL}}$ is expected to be negative and significantly less than $b_{\mathrm{KH}}$. The estimates of $b_{\mathrm{HL}}$ and $b_{\mathrm{HH}}$ are expected to be insignificant, support for the hypothesis that strength of the inverse relationship between leverage and profitability increases in the speed of reversion in profitability independent of industry concentration.

\subsection{Data and sample selection}

Financial data are from Compustat annual active and research files from 1982-2000. Only publicly traded (stock ownership codes 0 and 3), U.S.-incorporated firms are included in the sample. Firms with major mergers (footnote code AB) are excluded. A firm is included in the sample if the following data items are continuously available: positive net sales (item 12), operating income before depreciation (item 13), long-term debt (item 9), total assets (item 6), common equity (item 60), total equity (item 216), common shares outstanding at fiscal year end (item 25), and a closing common stock price at fiscal year end (item 199). Unreported (missing) depreciation expense (item 103) and/or R\&D expense (item 46) are recorded as zero. Firms with less than $\$ 10$ million in total assets and less than $\$ 5$ million in common equity are excluded to avoid extreme values when these variables are used as scale factors (as in Fama and French, 2000). 


\subsection{Results}

A total of 713 firms pass the sampling screens. Descriptive statistics for the variables used in the regression are given in Table 1 . The average leverage ratio is 0.69 . Operating profitability of the average firm year is $12 \%$ of total assets. The average speed of reversion in profitability is 0.76 with a standard deviation of 0.65 . The unscaled average Herfindahl-Hirschman index is 2,309 with a standard deviation of 1,955. Although the average firm in the sample is classified as belonging to a concentrated industry according to U.S. government guidelines, the empirical tests rely on the mean plus/minus one standard deviation which gives reasonable estimates of an $\mathrm{HHI}$ for a highly concentrated versus highly competitive industry.

The correlation coefficients for the variables used in the regression are in Table 2. The $\mathrm{K}$ is weakly negatively correlated with $\operatorname{LEV}(\rho=-0.02, p=0.01), \mathrm{H}$ and LEV are weakly inversely related $(\rho=-0.02, p=0.06)$. Of interest is the lack of correlation between $\mathrm{K}$ and $\mathrm{H}$ (p-value $=0.503$ ), an observation that does not support the hypothesis that $\mathrm{K}$ is decreasing in H. THETA is inversely related to LEV $(\rho=-0.05, p<0.0001)$. All other explanatory variables are significantly correlated with LEV with the predicted signs.

The results from estimating eq. (3) are presented in Table 3. As in Sarkar and Zapatero (2003), the estimate for the influence of profitability (E) on leverage is insignificant. As expected, LEV is significantly positively related to $\mathrm{K}(\mathrm{t}=2.50)$, suggesting that $\mathrm{K}$ is a risk-reducing element. LEV is also positively related to $\mathrm{H}$ $(\mathrm{t}=4.08)$, suggesting that $\mathrm{H}$ is a proxy for long-run profitability. LEV is unrelated to $\mathrm{EK}$ (coefficient estimate is $0.21, \mathrm{t}=1.73$ ), but is significantly inversely related to $\mathrm{EH}$ 
(coefficient estimate is $-10.42, \mathrm{t}=-5.88$ ), indicating that $\mathrm{H}$ dominates $\mathrm{K}$ as an influence on leverage. The coefficient estimates for DEP and RD are statistically significant, but DEP is a positive influence on leverage counter to prediction. The estimate for SIZE is significant and positive, and the estimate for MTB is significant and positive, supporting the idea that high-growth firms demand more external funds.

The conditional responses of leverage to profitability, displayed in Panel A of Table 4, are consistent with the results in Table 3. The conditional responses for $\mathrm{K}$ are not statistically significant. The conditional responses for $\mathrm{H}$ are negative and significant. For a low $\mathrm{H}$, the estimate for $\mathrm{b}_{\mathrm{HL}}$ is -0.77 , which is significantly different from the estimate for $\mathrm{b}_{\mathrm{HH}}$ of -4.84 (t-statistic for difference in coefficients is $\mathbf{- 3 . 3 2}$ from Panel B). The responses of leverage to profitability conditional on $\mathrm{H}$ indicate that $\mathrm{H}$ drives the inverse relationship between leverage and profitability. Specifically, firms in concentrated industries have a greater downward adjustment in leverage in response to an upswing in profits. The speed of reversion in profitability does not provide an explanation for the different leverage responses to profitability between industry competitive structures. These results are dependent on estimates of the speed of reversion in profitability as well as the degree of industry concentration. The sensitivity of these results to these estimates is examined next.

\subsection{Robustness of results}

The above analysis indicates that the degree of industry concentration drives out the influence of the speed of reversion in profitability in the leverage-profitability relationship. Because the speed of reversion in profitability is theoretically important to 
understanding the differences between competitive structures, the results in Section 5 are examined in the context of three alternative methods of estimating this variable. The first alternative method is modeled after Fama and French (2000), the second alternative method follows Balvers, Wu, and Gilliland (2000) and is a variation of the Fama-French method, and the third method is a re-expression of eq. (2) as an AR(1) in first differences. The robustness of the results in Section 5 is also examined for an alternative definition of leverage. Eq. (3) is estimated for two alternative leverage definitions: market leverage, or the ratio of long-term debt to the market value of common equity, and the ratio of long-term debt to total assets as an alternative book leverage definition.

\subsubsection{Sensitivity to alternative estimates of reversion in profitability}

Fama and French model the change in profitability as a partial adjustment process, represented by the following two equations (firm subscripts omitted):

$$
\mathrm{E}_{\mathrm{t}}-\mathrm{E}_{\mathrm{t}-1}=\mathrm{c}_{0}+\mathrm{c}_{1}\left[\mathrm{E}_{\mathrm{t}-1}-\mathrm{E}\left(\mathrm{E}_{\mathrm{t}-1}\right)\right]+\mathrm{c}_{2}\left[\mathrm{E}_{\mathrm{t}-1}-\mathrm{E}_{\mathrm{t}-2}\right]+\mathrm{u}_{\mathrm{t}}
$$

or

$$
\mathrm{CP}_{\mathrm{t}}=\mathrm{c}_{0}+\mathrm{c}_{1} \mathrm{DFE}_{\mathrm{t}-1}+\mathrm{c}_{2} \mathrm{CP}_{\mathrm{t}-1}+\mathrm{u}_{\mathrm{t}}
$$

Profitability (E) is defined as annual earnings before interest, taxes, and depreciation (EBITDA) divided by concurrent total assets. The partial adjustment term, $\mathrm{DFE}_{\mathrm{t}-1}=\mathrm{E}_{\mathrm{t}-1}$ $E\left(E_{t-1}\right)$ is the deviation of profitability from its expected value, included to represent the predictable variation in profitability. The coefficient for DFE, $\mathrm{c}_{1}$, may be viewed as the speed of mean reversion $(\kappa)$. The lagged change in profitability, $\mathrm{CP}_{\mathrm{t}-1}=\mathrm{E}_{\mathrm{t}-1}-\mathrm{E}_{\mathrm{t}-2}$ 
represents any autoregression not captured by DFE, and its coefficient $\left(\mathrm{c}_{2}\right)$ measures firstorder autocorrelation. If profitability is mean reverting, then the coefficient estimates of $\mathrm{E}_{\mathrm{t}}$ 1 and $\mathrm{E}\left(\mathrm{E}_{\mathrm{t}-1}\right)$ are expected to be equal in absolute value. If DFE does not fully represent the variation in profitability, then $\mathrm{CP}_{t}$ is expected to be significantly inversely related to $\mathrm{CP}_{t-1}$. Long run expected profitability $(\theta)$ is estimated as the mean expected profitability from eq. (6) below, and earnings volatility $(\sigma)$ is estimated as the standard deviation of the residuals in eq. (5b).

Expected profitability is calculated using fitted values from the following regression from Fama and French (2000):

$$
\mathrm{E}_{\mathrm{t}-1}=\mathrm{a}_{0}+\mathrm{a}_{1} \mathrm{~V}_{\mathrm{t}-1}+\mathrm{a}_{2} \mathrm{DD}_{\mathrm{t}-1}+\mathrm{a}_{3} \mathrm{D}_{\mathrm{t}-1} / \mathrm{BE}_{\mathrm{t}-1}+\mathrm{u}_{\mathrm{t}-1}
$$

The dependent variable, E, is profitability (EBITDA). D is dividends over the period, and BE is the book value of common equity. Fama and French include D/BE based on Miller's and Modigliani's (1961) hypothesis that firms set dividends according to permanent earnings, and thus dividends are informative about expected earnings. The predicted sign of $\mathrm{D} / \mathrm{BE}$ is positive. $\mathrm{V}$ is the end-of-period market value of common equity scaled by total assets. The market-to-book ratio is intended to account for the variation in expected profitability not picked up by dividends, and profitability is expected to vary directly with $\mathrm{V}$. DD is an indicator of whether or not the firm pays dividends, where DD=1 for non-dividend payers. Fama and French (1999) show that non-dividend paying firms tend to be less profitable than dividend payers, thus profitability is expected to vary inversely with DD. 
Eqs. (6) and (5b) are estimated for each firm with a 19-year continuous profitability series from 1982-2000, among other data requirements. The statistical significance of the speed of mean reversion parameter estimate is not an issue in this case. The coefficient estimate of DFE measures the marginal response of the change in current profitability to the deviation of last-period's profitability from its expectation. Some firms may have profitability that is relatively unresponsive to the difference from expectation of last-period's profitability. These firms arguably have a relatively low speed of mean reversion in profitability. Therefore, eq. (3) is estimated for 19-year continuous profitability series without regard to the statistical significance of the estimate of $\mathrm{c}_{1}$ from eq. (5b).

The estimation procedure reduces the sample to 741 firms. The average $\mathrm{K}$ for this sample is 0.83 with a standard deviation of 0.44 , and the average (unscaled) $\mathrm{H}$ is 2,279 with a standard deviation of 1,937 . When $\mathrm{K}$ is estimated using the method in Sarkar and Zapatero (2003), $\mathrm{K}$ and $\mathrm{H}$ are independent of each other, a finding that fails to support the second hypothesis. For the Fama and French (2002) method of estimating K, K and H are weakly positively correlated ( $\rho=0.07$, $\mathrm{p}$-value $<.0001)$, indicating that as measured, $\mathrm{H}$ is weakly related to $\mathrm{K}$.

The results from estimating eq. (3) with the alternate estimation of the speed of reversion strongly support the findings in the previous section. The regression results are in Table 5. The coefficient estimate for $\mathrm{E}$ is positive and significant $(\mathrm{t}=3.60)$. The estimate for $\mathrm{K}$ is insignificant $(\mathrm{t}=0.79)$, but the estimate for the influence of $\mathrm{H}$ on leverage is significant and positive ( $\mathrm{t}=3.76$ ). EK is not significant $(\mathrm{t}=0.10)$, and again EH is the dominant influence in the conditional response of leverage to profitability $(\mathrm{t}=-5.86)$. 
The conditional responses of leverage to profitability in Panel A of Table 6 confirm that industry concentration is the driver of the inverse relationship between leverage and profitability. The estimates of $b_{\mathrm{HL}}$ and $\mathrm{b}_{\mathrm{HH}}$ are both statistically different from each other (t-statistic for the difference in coefficients is -3.09). These estimates support the leverage-profitability relationships found in Section 5. This relationship appears to be driven by the degree of industry concentration, and the speed of reversion in profitability does not affect this result.

Balvers, Wu, and Gilliland (2000) model the change in profitability as:

$$
\mathrm{E}_{\mathrm{t}}-\mathrm{E}_{\mathrm{t}-1}=\mathrm{d}_{0}+\mathrm{d}_{1}\left[\mathrm{E}\left(\mathrm{E}_{\mathrm{t}}\right)-\mathrm{E}_{\mathrm{t}-1}\right]+\mathrm{d}_{2}\left[\mathrm{E}_{\mathrm{t}-1}-\mathrm{E}_{\mathrm{t}-2}\right]+\mathrm{u}_{\mathrm{t}}
$$

Eq. (7) is essentially the same representation of the change in current profitability as in eq. (5). However, the mean reversion parameter $\left(d_{1}\right)$ captures the relationship between the change in profitability and the deviation of last-period's profitability from its trend value, $\mathrm{E}\left(\mathrm{E}_{\mathrm{t}}\right)$. All variables are defined as above, with the exception of $\mathrm{E}\left(\mathrm{E}_{\mathrm{t}}\right)$, which is the expectation of current profitability. $\mathrm{E}\left(\mathrm{E}_{\mathrm{t}}\right)$ is estimated via eq. (6) for current profitability. Long run mean profitability and earnings volatility are estimated as in the previous method.

Eqs. (6) and (7) are estimated for each firm without regard to the statistical significance of the parameter estimates. The sample is defined as in Section 4, and each firm is required to have a 19-year continuous profitability series from 1982-2000, among other data requirements. Eq. (3) is estimated for the cross section of firm years, and results are reported in Table 7. 
A total of 741 firms survive the sampling procedure. The average $\mathrm{K}$ for this sample is 0.90 with a standard deviation of 0.36 , and the average (unscaled) $\mathrm{H}$ is 2,279 with a standard deviation of $1,937 . \mathrm{K}$ and $\mathrm{H}$ are weakly positively correlated for this method of estimating $\mathrm{K}$ ( $\rho=0.07$, p-value $<.0001)$, indicating that $\mathrm{H}$ is not sufficient for $\mathrm{K}$.

The results from estimating eq. (3) with the second alternate technique for estimating the speed of reversion also strongly support the findings in Section 5. The results reported in Table 7 indicate that profitability is not a significant factor in explaining leverage when the speed of reversion and other components are included in the regression, and the conditional responses are dominated by the joint influence of profitability and industry concentration, not the speed of reversion in profitability. The conditional responses of leverage to profitability are displayed in Panel A of Table 8. All conditional responses of leverage to profitability are significantly negative. The estimate for $b_{\mathrm{KL}}$ is statistically the same as the estimate for $b_{\mathrm{KH}}(\mathrm{t}$-statistic for the difference in coefficients is -0.93 ). The estimates for $b_{\mathrm{HL}}$ and $b_{\mathrm{HH}}$ are significantly negative and statistically distinct (t-statistic for the difference in coefficients is -2.28), again suggesting that the influence of industry concentration drives out any influence of the speed of reversion in profitability on the leverage-profitability relationship.

The last alternate method for estimating the speed of reversion is a re-expression of eq. (2) from Sarkar and Zapatero (2003). Eq. (2) below is expressed as

$$
\mathrm{E}_{\mathrm{t}}=\alpha+\lambda \mathrm{E}_{\mathrm{t}-1}+\mathrm{u}_{\mathrm{t}}
$$


The slope coefficient, $\lambda$, is equivalent to $\left(1+\mathrm{a}_{0}\right)$ in eq. (2). Profitability (E) is defined as EBITDA divided by concurrent total assets. Eq. (2a) is estimated using first differences for each firm in the sample from 1984-2000, and included firms have a 19-year survivor requirement (two lag years are needed for first differences). Only firms with estimates of $\lambda \leq 0$ are retained.

A total of 10,999 firm years survive the data requirements necessary for estimation on eq. (3). The mean and standard deviation for the speed of reversion are 0.37 and 0.19 , lower than $\mathrm{K}$ from other estimation methods. The unscaled mean and standard deviation for the indicator of industry concentration are 2,290 and 1,942. The estimates for $\mathrm{K}$ are again unrelated to $\mathrm{H}(\rho=-0.01$, $\mathrm{p}$-value $=0.17)$.

Table 9 shows the results from estimating eq. (3). The coefficient estimate for $\mathrm{E}$ is not related to LEV ( $\mathrm{t}=-1.79)$. $\mathrm{K}$ is also not related to LEV ( $\mathrm{t}=-0.93)$, and $\mathrm{H}$ and LEV are unrelated $(\mathrm{t}=0.35)$. The estimate of EK is insignificant $(\mathrm{t}=0.20)$, and the estimate for EH is significantly negative ( $t=-4.30)$. The response of leverage to profitability conditional on $\mathrm{H}$ is significant only with a higher value of $\mathrm{H}$, as reported in Panel $\mathrm{A}$ of Table 10. H again intensifies the inverse relationship between leverage and profitability, whereas $\mathrm{K}$ is unimportant.

\subsubsection{Sensitivity to alternative definitions of leverage}

The results in Section 5 are re-estimated for two alternative leverage definitions: market leverage, or the ratio of long-term debt to the market value of common equity (LTD/ME) and long term debt divided by total assets (LTD/TA). Sarkar and Zapatero (2003) use LTD/ME as the dependent variable for examining the influence of the speed 
of reversion on leverage. The speed of reversion is estimated for each firm as in Section 5, and all other variable definitions are the same. The coefficient estimates for eq. (3) with the two alternate leverage definitions are reported in Table 11.

The regression results for the two alternative leverage definitions generally agree with the estimates in Section 5. Profitability is not significant for LTD/ME. Profitability is significantly positive for LTD/TA, indicating that long-term debt levels and current profitability are related, unlike the prediction in Sarkar and Zapatero (2003) that the coupon is set to long-run mean profitability. As predicted, the speed of reversion in profitability is significantly positive for LTD/ME and LTD/TA. For both long-term leverage definitions, the degree of industry concentration is positive and significant, EK is not significant, EH is significantly negative. The coefficient estimates for the two alternative definitions of long-term debt collectively indicate that the speed of reversion in profitability does not drive the inverse relationship between leverage and profitability. The dominant influence on this relationship is the degree of industry concentration, an observation that is supported by the conditional marginal responses in Table 12 .

The main results in Section 5 are not sensitive to alternative leverage definitions that are ratios of long-term debt to some measure of firm value. The degree of industry concentration affects the leverage-profitability relationship and overrides any influence of the speed of reversion.

\subsubsection{Sensitivity to the definition of industry concentration}

The previous results rely on estimates of the degree of industry concentration by way of calculating the Herfindahl-Hirschman Index (HHI) by 4-digit SIC code from the 
Compustat universe. An alternative measure of industry concentration is the reported HHI from the U.S. Census Bureau for manufacturing firms. The Census measure of industry concentration is potentially more accurate due to the inclusion of both privately and publicly held firms in the calculation of HHI. These HHI are used to check the robustness of the results to the definition of the industry concentration variable. The alternative measure of industry concentration is the HHI reported for 1992, which is approximately the midpoint of the time series. This choice eliminates time variation and reduces noise in the measure of industry concentration. Eq. (3) is estimated as described in Section 4 for this alternative definition of $\mathrm{H}$.

A total of 4,320 manufacturing firm years are included in the estimation of eq. (3). The average $\mathrm{K}$ for this sample is 0.78 with a standard deviation of 0.45 . The average (unscaled) $\mathrm{H}$ is 575 with a standard deviation of 539 , indicating that the average manufacturing firm operates in an unconcentrated industry. The estimate for the speed of reversion is significantly inversely related to the indicator of industry concentration for manufacturing firms $(\rho=-0.13$, $p$-value $<.0001)$, suggesting that $\mathrm{K}$ and $\mathrm{H}$ are weak substitutes. This finding supports the fourth hypothesis, that firms in concentrated industries have slower speeds of reversion in profitability. The estimates of the coefficients in eq. (3) for manufacturing firms differ considerably from those in Section 5. From Table 13, the estimate for $\mathrm{E}$ is significantly negative and large $(-7.63, \mathrm{t}=-3.60)$, the estimate for $\mathrm{K}$ is insignificant $(\mathrm{t}=-1.67)$, and the estimate for $\mathrm{H}$ is positive but insignificant $(\mathrm{t}=1.88)$. Contrary to the results in Section 5, EK is significant and positive (3.37, $\mathrm{t}=2.68)$, but $\mathrm{EH}$ is not significant $(\mathrm{t}=0.62)$. 
The estimated conditional responses to leverage shown in Panel A of Table 14 are negative and significant. However, the responses of leverage to profitability conditional on high and low values of $\mathrm{K}$ are not significantly different. The results for the alternative definition of industry concentration generally support the hypothesis that the speed of reversion in profitability is sufficient for industry concentration as an explanation for differing leverage-profitability responses.

\subsection{Conclusion}

This study tests and finds that the response of leverage to profitability is different for firms in concentrated industries as opposed to more competitive industries, a result that cannot be explained by differences in the speed of reversion in profitability when Compustat data are used to approximate industry concentration. The results are robust to alternative methods of estimating the speed of reversion in profitability and alternative definitions of leverage. When the conditional responses of leverage to profitability are estimated with U.S. Census Bureau measures of industry concentration for manufacturing firms, the predictions of this study are generally supported. Industry concentration is inversely related to the speed of reversion in profitability, and the speed of reversion in profitability is sufficient for industry concentration in explaining why firms in concentrated industries have leverage that is more sensitive to profitability compared to firms in more competitive industries. 


\section{References}

Balvers, Ronald, Yangru Wu, and Erik Gilliland, 2000, Mean Reversion across National Stock Markets and Parametric Contrarian Investment Strategies, Journal of Finance 55:2 (April), 745-772.

Bhattacharya, S., 1978, Project Valuation with Mean Reverting Cash Flow Streams, Journal of Finance 33, 1317-31.

Bradley, Michael, Gregg A. Jarrell, and E. Han Kim, 1984, On the Existence of an Optimal Capital Structure: Theory and Evidence, Journal of Finance 39:3 (July), 857878.

Delorme, Charles D., Jr., et al., 2003, Structure, Conduct and Performance: A Simultaneous Equations Approach, Applied Economics 35:1 (January), 13-20.

Domowitz, Ian , R. Glenn Hubbard, and Bruce C. Petersen, 1988, Market Structure and Cyclical Fluctuations in U.S. Manufacturing, Review of Economics and Statistics 70:1 (February), 55-66.

Fama, Eugene F., and Kenneth R. French, 2000, Forecasting Profitability and Earnings, Journal of Business 73:2 (April), 161-75.

Fama, Eugene F., and Kenneth R. French, 2002, Testing Trade-Off and Pecking Order Predictions about Dividends and Debt, Review of Financial Studies 15:1 (Spring), 1-33.

Hou, Kewei, and David T. Robinson, 2006, Industry Concentration and Average Stock Returns, Journal of Finance 61:4 (August), 1927-56.

Leland, Hayne E., 1994, Corporate Debt Value, Bond Covenants, and Optimal Capital Structure, Journal of Finance 49:4 (September), 1213-52.

Lev, Baruch, 1983, Some Economic Determinants of Time-Series Properties of Earnings, Journal of Accounting and Economics 5:1 (April), 31-48.

MacKay, Peter, and Gordon M. Phillips, 2005, How Does Industry Affect Firm Financial Structure? Review of Financial Studies 18:4 (Winter), 1433-66.

Miller, Merton H., and F. Modigliani, 1961, Dividend Policy, Growth, and the Valuation of Shares, Journal of Business 34 (October), 411-33.

Raymar, Steven, 1991, A Model of Capital Structure When Earnings Are MeanReverting, Journal of Financial and Quantitative Analysis 26:3 (September), 327-44. 
Sarkar, Sudipto and Fernando Zapatero, 2003, The Trade-Off Model with Mean Reverting Earnings: Theory and Empirical Tests, Economic Journal 113:490 (October), 834-60. 


\section{Table 3.1: Descriptive statistics for regression variables}

Annual data are from Compustat from 1982-2000. In the following, LEV is long-term debt (Compustat item 9) scaled by the book value of common equity (60). E is EBITDA, or earnings before interest, taxes, depreciation, and amortization (13) scaled by total assets (6). $\mathrm{K}$ is the speed of reversion in EBITDA (estimated via the method in Sarkar and Zapatero, 2003), $\mathrm{H}$ is the Herfindahl-Hirschman Index calculated annually by SIC from the universe of Compustat firms with positive sales (12), then scaled by 10,000. EK, $\mathrm{EH}, \mathrm{KH}$, and EKH are interaction terms. DEP is depreciation and amortization (125), RD is research and development expense (46). These variables are scaled by total assets (6). SIZE is the natural log of total assets (6), and MTB is the market value of common equity $\left(25^{*} 199\right)$ divided by the book value of common equity (60).

\begin{tabular}{lcc}
\hline $\mathrm{N}=12,834$ & Mean & Std. Dev. \\
\hline LEV & 0.69 & \\
$\mathrm{E}$ & 0.12 & 1.56 \\
$\mathrm{~K}$ & 0.76 & 0.07 \\
THETA & 0.11 & 0.65 \\
SIGMA & 0.52 & 0.08 \\
$\mathrm{H}$ & 0.23 & 1.06 \\
DEP & 0.04 & 0.20 \\
RD & 0.02 & 0.03 \\
SIZE & 6.68 & 0.03 \\
MTB & 2.20 & 1.98 \\
\end{tabular}




\section{Table 3.2: Pearson correlation coefficients for regression variables}

Annual data are from Compustat from 1982-2000. In the following, LEV is long-term debt (Compustat item 9) scaled by the book value of common equity (60). E is EBITDA, or earnings before interest, taxes, depreciation, and amortization (13) scaled by total assets (6). $\mathrm{K}$ is the speed of reversion in EBITDA, THETA is long run mean earnings, and SIGMA is earnings volatility (estimated via the method in Sarkar and Zapatero, 2003). $\mathrm{H}$ is the Herfindahl-Hirschman Index calculated annually by SIC from the universe of Compustat firms with positive sales (12), then scaled by 10,000. EK, EH, KH, and EKH are interaction terms. DEP is depreciation and amortization (125), RD is research and development expense (46). These variables are scaled by total assets (6). SIZE is the natural log of total assets (6), and MTB is the market value of common equity $\left(25^{*} 199\right)$ divided by the book value of common equity (60).

\begin{tabular}{|c|c|c|c|c|c|c|c|c|c|c|}
\hline & LEV & $\mathbf{E}$ & $\mathbf{K}$ & THETA & SIGMA & $\mathbf{H}$ & DEP & RD & SIZE & МТВ \\
\hline LEV & 1.00 & $\begin{array}{c}-0.07 \\
<.0001\end{array}$ & $\begin{array}{c}-0.02 \\
0.0164\end{array}$ & $\begin{array}{c}-0.05 \\
<.0001\end{array}$ & $\begin{array}{c}-0.04 \\
<.0001\end{array}$ & $\begin{array}{c}-0.02 \\
0.0620\end{array}$ & $\begin{array}{c}-0.03 \\
0.0004\end{array}$ & $\begin{array}{c}-0.11 \\
<.0001\end{array}$ & $\begin{array}{c}0.19 \\
<.0001\end{array}$ & $\begin{array}{c}0.21 \\
<.0001\end{array}$ \\
\hline $\mathbf{E}$ & $\begin{array}{c}-0.07 \\
<.0001\end{array}$ & 1.00 & $\begin{array}{c}-0.04 \\
<.0001\end{array}$ & $\begin{array}{c}0.46 \\
<.0001\end{array}$ & $\begin{array}{c}-0.16 \\
<.0001\end{array}$ & $\begin{array}{c}0.12 \\
<.0001\end{array}$ & $\begin{array}{c}0.40 \\
<.0001\end{array}$ & $\begin{array}{c}0.07 \\
<.0001\end{array}$ & $\begin{array}{c}-0.12 \\
<.0001\end{array}$ & $\begin{array}{c}0.26 \\
<.0001\end{array}$ \\
\hline $\mathbf{K}$ & $\begin{array}{c}-0.02 \\
0.0164\end{array}$ & $\begin{array}{c}-0.04 \\
<.0001\end{array}$ & 1.00 & $\begin{array}{c}-0.10 \\
<.0001\end{array}$ & $\begin{array}{c}0.57 \\
<.0001\end{array}$ & $\begin{array}{c}-0.01 \\
0.5025\end{array}$ & $\begin{array}{c}0.04 \\
<.0001\end{array}$ & $\begin{array}{c}0.08 \\
<.0001\end{array}$ & $\begin{array}{c}-0.05 \\
<.0001\end{array}$ & $\begin{array}{l}-0.05 \\
<.0001\end{array}$ \\
\hline THETA & $\begin{array}{c}-0.05 \\
<.0001\end{array}$ & $\begin{array}{c}0.46 \\
<.0001\end{array}$ & $\begin{array}{l}-0.10 \\
<.0001\end{array}$ & 1.00 & $\begin{array}{c}-0.09 \\
<.0001\end{array}$ & $\begin{array}{c}0.11 \\
<.0001\end{array}$ & $\begin{array}{c}0.29 \\
<.0001\end{array}$ & $\begin{array}{c}0.09 \\
<.0001\end{array}$ & $\begin{array}{c}-0.07 \\
<.0001\end{array}$ & $\begin{array}{c}0.19 \\
<.0001\end{array}$ \\
\hline SIGMA & $\begin{array}{c}-0.04 \\
<.0001\end{array}$ & $\begin{array}{c}-0.16 \\
<.0001\end{array}$ & $\begin{array}{c}0.57 \\
<.0001\end{array}$ & $\begin{array}{c}-0.09 \\
<.0001\end{array}$ & 1.00 & $\begin{array}{c}0.03 \\
0.0041\end{array}$ & $\begin{array}{c}-0.08 \\
<.0001\end{array}$ & $\begin{array}{c}0.13 \\
<.0001\end{array}$ & $\begin{array}{l}-0.15 \\
<.0001\end{array}$ & $\begin{array}{l}-0.05 \\
<.0001\end{array}$ \\
\hline $\mathbf{H}$ & $\begin{array}{c}-0.02 \\
0.0620\end{array}$ & $\begin{array}{c}0.12 \\
<.0001\end{array}$ & $\begin{array}{c}-0.01 \\
0.5025\end{array}$ & $\begin{array}{c}0.11 \\
<.0001\end{array}$ & $\begin{array}{c}0.03 \\
0.0041\end{array}$ & 1.00 & $\begin{array}{c}0.07 \\
<.0001\end{array}$ & $\begin{array}{c}0.13 \\
<.0001\end{array}$ & $\begin{array}{c}-0.18 \\
<.0001\end{array}$ & $\begin{array}{c}0.06 \\
<.0001\end{array}$ \\
\hline DEP & $\begin{array}{c}-0.03 \\
0.0004\end{array}$ & $\begin{array}{c}0.40 \\
<.0001\end{array}$ & $\begin{array}{c}0.04 \\
<.0001\end{array}$ & $\begin{array}{c}0.29 \\
<.0001\end{array}$ & $\begin{array}{c}-0.08 \\
<.0001\end{array}$ & $\begin{array}{c}0.07 \\
<.0001\end{array}$ & 1.00 & $\begin{array}{c}0.14 \\
<.0001\end{array}$ & $\begin{array}{c}-0.13 \\
<.0001\end{array}$ & $\begin{array}{c}0.03 \\
0.0026\end{array}$ \\
\hline RD & $\begin{array}{c}-0.11 \\
<.0001\end{array}$ & $\begin{array}{c}0.07 \\
<.0001\end{array}$ & $\begin{array}{c}0.08 \\
<.0001\end{array}$ & $\begin{array}{c}0.09 \\
<.0001\end{array}$ & $\begin{array}{c}0.13 \\
<.0001\end{array}$ & $\begin{array}{c}0.13 \\
<.0001\end{array}$ & $\begin{array}{c}0.14 \\
<.0001\end{array}$ & 1.00 & $\begin{array}{c}-0.09 \\
<.0001\end{array}$ & $\begin{aligned} & 0.13 \\
< & .0001\end{aligned}$ \\
\hline SIZE & $\begin{array}{c}0.19 \\
<.0001\end{array}$ & $\begin{array}{c}-0.12 \\
<.0001\end{array}$ & $\begin{array}{l}-0.05 \\
<.0001\end{array}$ & $\begin{array}{c}-0.07 \\
<.0001\end{array}$ & $\begin{array}{c}-0.15 \\
<.0001\end{array}$ & $\begin{array}{c}-0.18 \\
<.0001\end{array}$ & $\begin{array}{c}-0.13 \\
<.0001\end{array}$ & $\begin{array}{c}-0.09 \\
<.0001\end{array}$ & 1.00 & $\begin{array}{c}0.11 \\
<.0001\end{array}$ \\
\hline МТВ & $\begin{array}{c}0.21 \\
<.0001\end{array}$ & $\begin{array}{c}0.26 \\
<.0001\end{array}$ & $\begin{array}{c}-0.05 \\
<.0001\end{array}$ & $\begin{array}{c}0.19 \\
<.0001\end{array}$ & $\begin{array}{c}-0.05 \\
<.0001\end{array}$ & $\begin{array}{c}0.06 \\
<.0001\end{array}$ & $\begin{array}{c}0.03 \\
0.0026\end{array}$ & $\begin{array}{c}0.13 \\
<.0001\end{array}$ & $\begin{array}{c}0.11 \\
<.0001\end{array}$ & 1.00 \\
\hline
\end{tabular}




\section{Table 3.3: Regression results for book leverage}

Annual data are from Compustat from 1982-2000. In the following, LEV is long-term debt (Compustat item 9) scaled by the book value of common equity (60). E is EBITDA, or earnings before interest, taxes, depreciation, and amortization (13) scaled by total assets (6). $\mathrm{K}$ is the speed of reversion in EBITDA, THETA is long run mean earnings, and SIGMA is earnings volatility. $\mathrm{H}$ is the Herfindahl-Hirschman Index calculated annually by SIC from the universe of Compustat firms with positive sales (12), then scaled by 10,000. EK, EH, and KH are interaction terms. DEP is depreciation and amortization (125), RD is research and development expense (46). These variables are scaled by total assets (6). SIZE is the natural log of total assets (6), and MTB is the market value of common equity $\left(25^{*} 199\right)$ divided by the book value of common equity (60). Asymptotic standard errors of the estimates are used to calculate t-statistics. The prediction of "n.s." represents not significant.

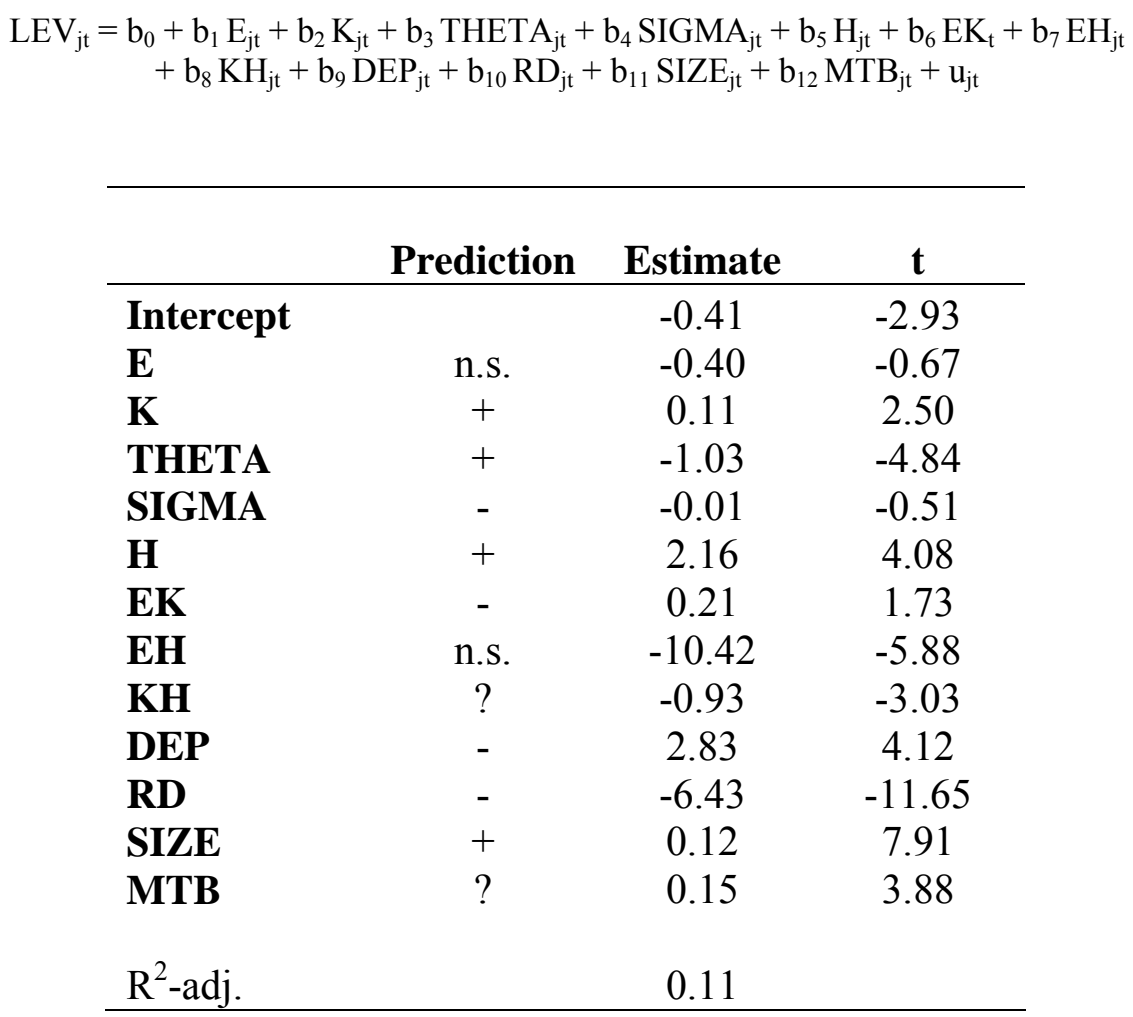




\section{Table 3.4: Two-way interactions, book leverage}

\section{Panel A: Conditional response of leverage to profitability}

The formulas below are used to calculate the marginal responses of leverage to profitability, conditional on the speed of reversion in profitability $(\mathrm{K})$ and industry concentration $(\mathrm{H})$. The conditional marginal responses are based on coefficient estimates from Table 3 and the means and standard deviations of the distributions of $\mathrm{K}$ and $\mathrm{H}$. LEV is defined long-term debt (9) divided by the market value of common equity $\left(25^{*} 199\right), \mathrm{K}$ is the speed of reversion in EBITDA estimated via the method in Sarkar and Zapatero (2003). K low (high) is the mean of the $\mathrm{K}$ distribution minus (plus) one standard deviation. $\mathrm{H}$ low (high) is the mean of the $\mathrm{H}$ distribution minus (plus) one standard deviation. Asymptotic standard errors of the estimates in Table 3 are used to calculate t-statistics (in parentheses) for each conditional marginal response.

\begin{tabular}{|l|cc|}
\hline \multicolumn{3}{|c|}{ Marginal response of leverage to profitability conditional on the } \\
\hline \multicolumn{2}{|c|}{ Speed of reversion in profitability } & Degree of industry concentration \\
$\left.\hat{b}\right|_{K}=\left.\frac{\partial L E V}{\partial E}\right|_{\bar{K} \pm \sigma_{K}}=\hat{b}_{1}+\hat{b}_{6}\left(\bar{K} \pm \sigma_{K}\right)$ & $\left.\hat{b}\right|_{H}=\left.\frac{\partial L E V}{\partial E}\right|_{\bar{H} \pm \sigma_{H}}=\hat{b}_{1}+\hat{b}_{7}\left(\bar{H} \pm \sigma_{H}\right)$ \\
\hline K low & H low & -0.77 \\
& & $(-1.37)$ \\
K high & H high & -4.84 \\
& 0 & $(-7.27)$ \\
\hline
\end{tabular}

\section{Panel B: Test statistics for differences in conditional coefficients}

T-statistics for the indicated differences in conditional coefficients are presented in the tables below. P-values are in parentheses (onetailed test).
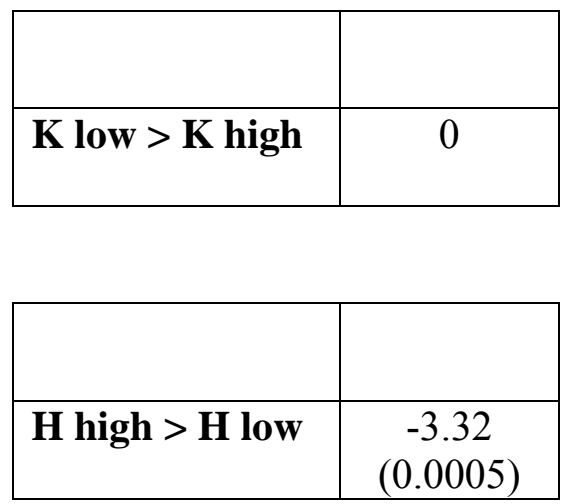


\section{Table 3.5}

\section{Robustness to Fama and French (2002) method of estimating reversion in profitability: regression results}

Annual data are from Compustat from 1982-2000. In the following, LEV is long-term debt (Compustat item 9) scaled by the book value of common equity (60). E is EBITDA, or earnings before interest, taxes, depreciation, and amortization (13) scaled by total assets (6). $\mathrm{K}$ is the speed of reversion in EBITDA, THETA is long run mean earnings, and SIGMA is earnings volatility (estimated via the method in Fama and French, 2002). H is the Herfindahl-Hirschman Index calculated annually by SIC from the universe of Compustat firms with positive sales (12), then scaled by 10,000. EK, EH, and KH are interaction terms. DEP is depreciation and amortization (125), RD is research and development expense (46). These variables are scaled by total assets (6). SIZE is the natural $\log$ of total assets $(6)$, and MTB is the market value of common equity $\left(25^{*} 199\right)$ divided by the book value of common equity $(60)$. Asymptotic standard errors of the estimates are used to calculate t-statistics. The prediction of "n.s." represents not significant.

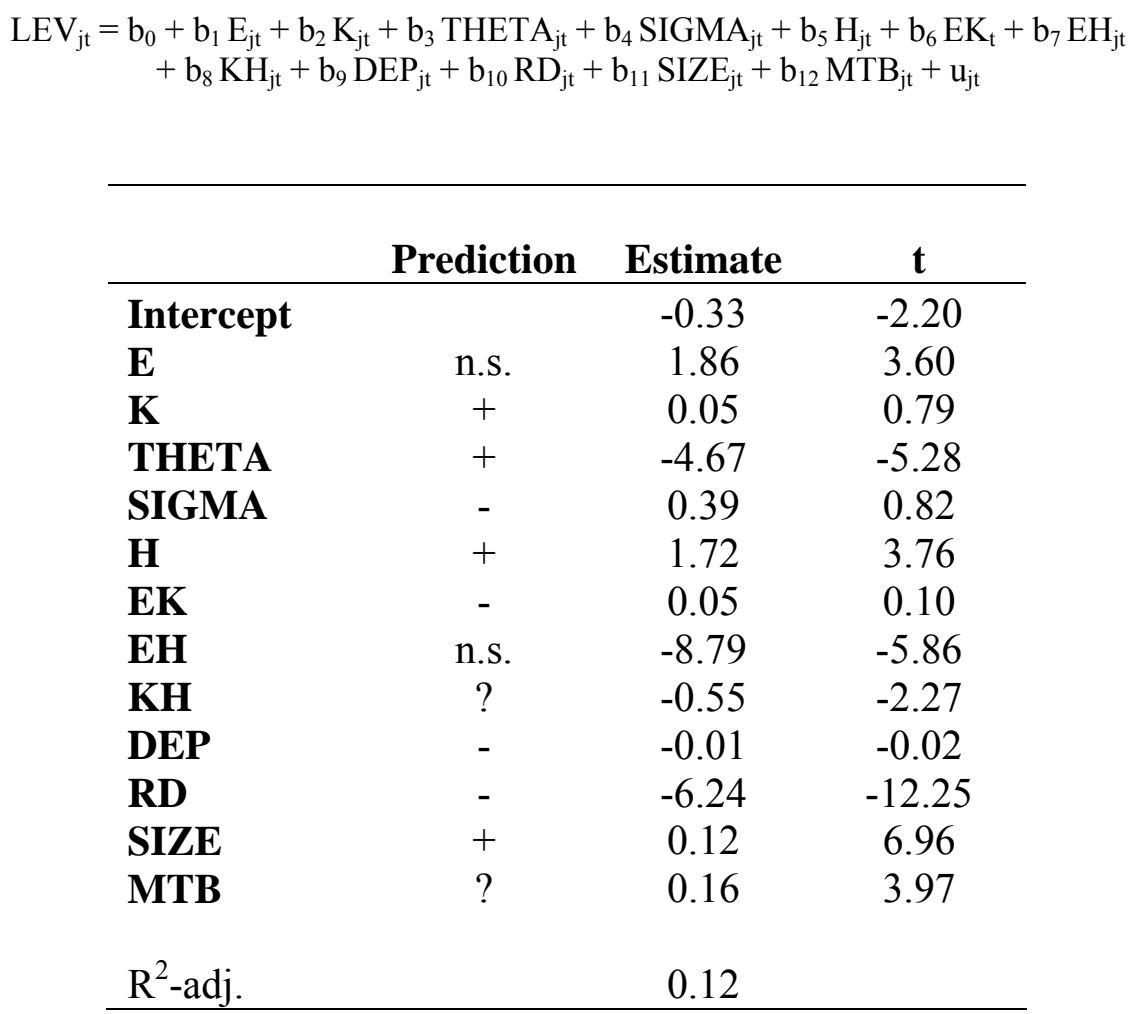


Table 3.6

Robustness to Fama and French (2002) method of estimating reversion in profitability: statistical tests

\section{Panel A: Conditional response of leverage to profitability}

The formulas below are used to calculate the marginal responses of leverage to profitability, conditional on the speed of reversion in profitability $(\mathrm{K})$ and industry concentration $(\mathrm{H})$. The conditional marginal responses are based on coefficient estimates from Table 5 and the means and standard deviations of the distributions of $\mathrm{K}$ and $\mathrm{H}$. LEV is defined as the ratio of total long term debt to the book value of equity, $\mathrm{K}$ is the speed of reversion in EBITDA estimated via the method in Fama and French (2002). K low (high) is the mean of the $\mathrm{K}$ distribution minus (plus) one standard deviation. $\mathrm{H}$ low (high) is the mean of the $\mathrm{H}$ distribution minus (plus) one standard deviation. Asymptotic standard errors of the estimates in Table 5 are used to calculate t-statistics (in parentheses) for each conditional marginal response.

Marginal response of leverage to profitability conditional on the

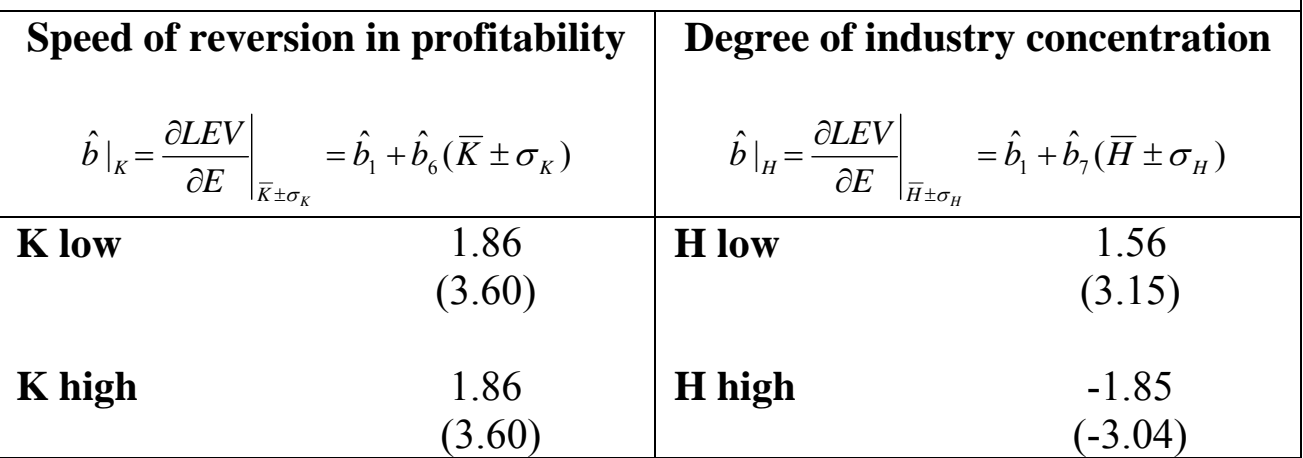

Panel B: Test statistics for differences in conditional coefficients

T-statistics for the indicated differences in conditional coefficients are presented in the tables below. P-values are in parentheses (onetailed test)
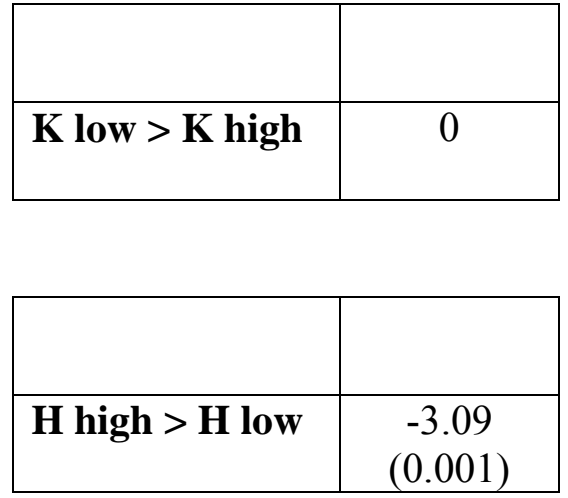


\section{Table 3.7}

\section{Robustness to Balvers, Wu, and Gilliland (2000) method of estimating reversion in profitability: regression results}

Annual data are from Compustat from 1982-2000. In the following, LEV is long-term debt (Compustat item 9) scaled by the book value of common equity (60). E is EBITDA, or earnings before interest, taxes, depreciation, and amortization (13) scaled by total assets (6). $\mathrm{K}$ is the speed of reversion in EBITDA, SIGMA is earnings volatility (estimated via the method in Balvers, Wu, and Gilliland, 2000). THETA is long run mean earnings (estimated via the method in Fama and French, 2002). H is the HerfindahlHirschman Index calculated annually by SIC from the universe of Compustat firms with positive sales (12), then scaled by 10,000. $\mathrm{EK}, \mathrm{EH}$, and $\mathrm{KH}$ are interaction terms. DEP is depreciation and amortization (125), RD is research and development expense (46). These variables are scaled by total assets (6). SIZE is the natural log of total assets (6), and MTB is the market value of common equity $\left(25^{*} 199\right)$ divided by the book value of common equity (60). Asymptotic standard errors of the estimates are used to calculate tstatistics. The prediction of "n.s." represents not significant.

$$
\begin{gathered}
\mathrm{LEV}_{\mathrm{jt}}=\mathrm{b}_{0}+\mathrm{b}_{1} \mathrm{E}_{\mathrm{jt}}+\mathrm{b}_{2} \mathrm{~K}_{\mathrm{jt}}+\mathrm{b}_{3} \text { THETA }_{\mathrm{jt}}+\mathrm{b}_{4} \text { SIGMA }_{\mathrm{jt}}+\mathrm{b}_{5} \mathrm{H}_{\mathrm{jt}}+\mathrm{b}_{6} \mathrm{EK}_{\mathrm{t}}+\mathrm{b}_{7} \mathrm{EH}_{\mathrm{jt}} \\
+\mathrm{b}_{8} \mathrm{KH}_{\mathrm{jt}}+\mathrm{b}_{9} \mathrm{DEP}_{\mathrm{jt}}+\mathrm{b}_{10} \mathrm{RD}_{\mathrm{jt}}+\mathrm{b}_{11} \text { SIZE }_{\mathrm{jt}}+\mathrm{b}_{12} \mathrm{MTB}_{\mathrm{jt}}+\mathrm{u}_{\mathrm{jt}}
\end{gathered}
$$

\begin{tabular}{lccc}
\hline & & & \\
& Prediction & Estimate & t \\
\hline Intercept & & -0.21 & -1.15 \\
E & n.s. & 1.38 & 1.84 \\
K & + & -0.03 & -0.32 \\
THETA & + & -4.75 & -5.39 \\
SIGMA & - & -0.20 & -0.35 \\
H & + & 1.83 & 3.26 \\
EK & - & 0.59 & 0.84 \\
EH & n.s. & -9.04 & -5.75 \\
KH & $?$ & -0.58 & -1.73 \\
DEP & - & 0.10 & 0.18 \\
RD & - & -6.16 & -12.12 \\
SIZE & + & 0.11 & 6.77 \\
MTB & $?$ & 0.16 & 3.98 \\
& & & \\
R $^{2}$-adj. & & 0.12 & \\
\hline
\end{tabular}




\section{Table 3.8}

Robustness to Balvers, Wu, and Gilliland (2000) method of estimating reversion in profitability: statistical tests

\section{Panel A: Conditional response of leverage to profitability}

The formulas below are used to calculate the marginal responses of leverage to profitability, conditional on the speed of reversion in profitability $(\mathrm{K})$ and industry concentration $(\mathrm{H})$. The conditional marginal responses are based on coefficient estimates from Table 7 and the means and standard deviations of the distributions of $\mathrm{K}$ and $\mathrm{H}$. LEV is defined as the ratio of total long term debt to the book value of equity, $\mathrm{K}$ is the speed of reversion in EBITDA estimated via the method in Balvers, Wu, and Gilliland (2000). K low (high) is the mean of the $\mathrm{K}$ distribution minus (plus) one standard deviation. $\mathrm{H}$ low (high) is the mean of the $\mathrm{H}$ distribution minus (plus) one standard deviation. Asymptotic standard errors of the estimates in Table 7 are used to calculate t-statistics (in parentheses) for each conditional marginal response.

\section{Marginal response of leverage to profitability conditional on the}

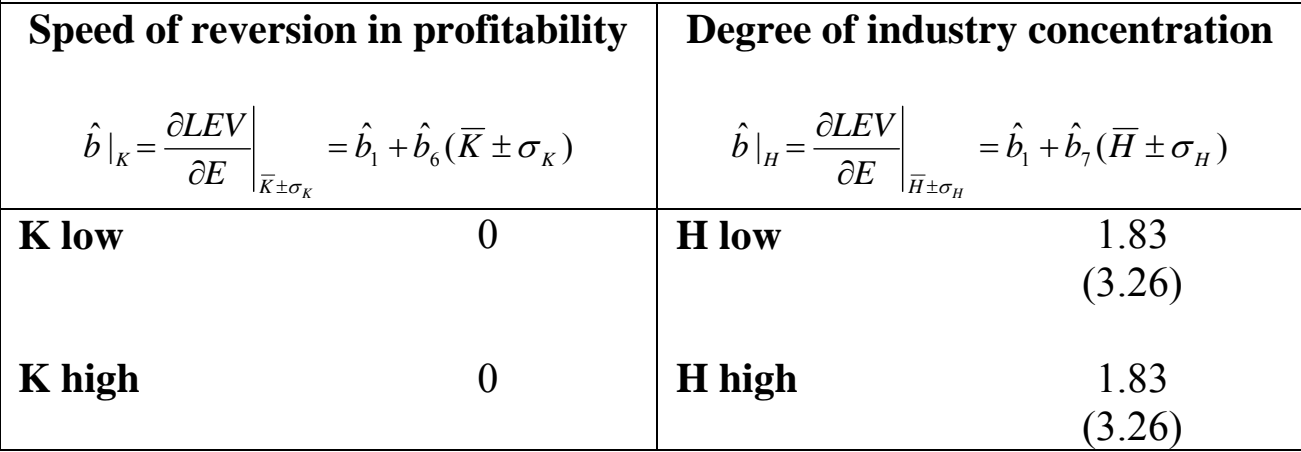

Panel B: Test statistics for differences in conditional coefficients

$\mathrm{T}$-statistics for the indicated differences in conditional coefficients are presented in the tables below. P-values are in parentheses (onetailed test).

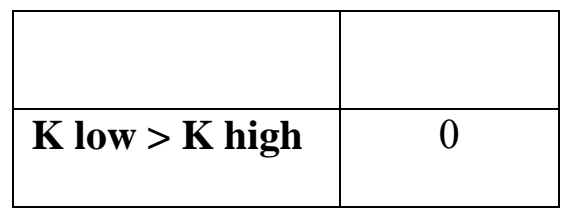

\begin{tabular}{|l|c|}
\hline & \\
\hline H high $>$ H low & 0 \\
\hline
\end{tabular}




\title{
Table 3.9
}

\section{Robustness to AR(1) method of estimating reversion in profitability: regression results}

\begin{abstract}
Annual data are from Compustat from 1982-2000. In the following, LEV is long-term debt (Compustat item 9) scaled by the book value of common equity (60). E is EBITDA, or earnings before interest, taxes, depreciation, and amortization (13) scaled by total assets (6). $\mathrm{K}$ is the speed of reversion in EBITDA, SIGMA is earnings volatility (estimated via first order autoregression). THETA is long run mean earnings (estimated via the method in Fama and French, 2002). $\mathrm{H}$ is the Herfindahl-Hirschman Index calculated annually by SIC from the universe of Compustat firms with positive sales (12), then scaled by 10,000. EK, EH, and KH are interaction terms. DEP is depreciation and amortization (125), RD is research and development expense (46). These variables are scaled by total assets (6). SIZE is the natural $\log$ of total assets (6), and MTB is the market value of common equity (25*199) divided by the book value of common equity (60). Asymptotic standard errors of the estimates are used to calculate t-statistics. The prediction of "n.s." represents not significant.
\end{abstract}

$$
\begin{gathered}
\mathrm{LEV}_{\mathrm{jt}}=\mathrm{b}_{0}+\mathrm{b}_{1} \mathrm{E}_{\mathrm{jt}}+\mathrm{b}_{2} \mathrm{~K}_{\mathrm{jt}}+\mathrm{b}_{3} \text { THETA }_{\mathrm{jt}}+\mathrm{b}_{4} \mathrm{SIGMA}_{\mathrm{jt}}+\mathrm{b}_{5} \mathrm{H}_{\mathrm{jt}}+\mathrm{b}_{6} \mathrm{EK}_{\mathrm{t}}+\mathrm{b}_{7} \mathrm{EH}_{\mathrm{jt}} \\
+\mathrm{b}_{8} \mathrm{KH}_{\mathrm{jt}}+\mathrm{b}_{9} \mathrm{DEP}_{\mathrm{jt}}+\mathrm{b}_{10} \mathrm{RD}_{\mathrm{jt}}+\mathrm{b}_{11} \mathrm{SIZE}_{\mathrm{jt}}+\mathrm{b}_{12} \mathrm{MTB}_{\mathrm{jt}}+\mathrm{u}_{\mathrm{jt}}
\end{gathered}
$$

\begin{tabular}{lccc}
\hline & Prediction & Estimate & t \\
\hline Intercept & & 0.29 & 3.42 \\
E & n.s. & -0.87 & -1.79 \\
K & + & -0.12 & -0.93 \\
THETA & + & -2.67 & -5.92 \\
SIGMA & - & 0.03 & 0.10 \\
H & + & 0.05 & 0.35 \\
EK & - & 0.16 & 0.20 \\
EH & n.s. & -4.41 & -4.30 \\
KH & $?$ & 0.64 & 2.54 \\
DEP & - & 3.74 & 7.80 \\
RD & - & -6.50 & -16.30 \\
SIZE & + & 0.06 & 7.38 \\
MTB & $?$ & 0.14 & 6.00 \\
& & & \\
R $^{2}$-adj. & & 0.18 & \\
\hline
\end{tabular}




\section{Table 3.10}

Robustness to AR(1) method of estimating reversion in profitability: statistical tests

\section{Panel A: Conditional response of leverage to profitability}

The formulas below are used to calculate the marginal responses of leverage to profitability, conditional on the speed of reversion in profitability $(\mathrm{K})$ and industry concentration $(\mathrm{H})$. The conditional marginal responses are based on coefficient estimates from Table 9 and the means and standard deviations of the distributions of $\mathrm{K}$ and $\mathrm{H}$. LEV is defined as the ratio of total long term debt to the book value of equity, $\mathrm{K}$ is the speed of reversion in EBITDA estimated via first order autoregression. $\mathrm{K}$ low (high) is the mean of the $\mathrm{K}$ distribution minus (plus) one standard deviation. $\mathrm{H}$ low (high) is the mean of the $\mathrm{H}$ distribution minus (plus) one standard deviation. Asymptotic standard errors of the estimates in Table 9 are used to calculate t-statistics (in parentheses) for each conditional marginal response.

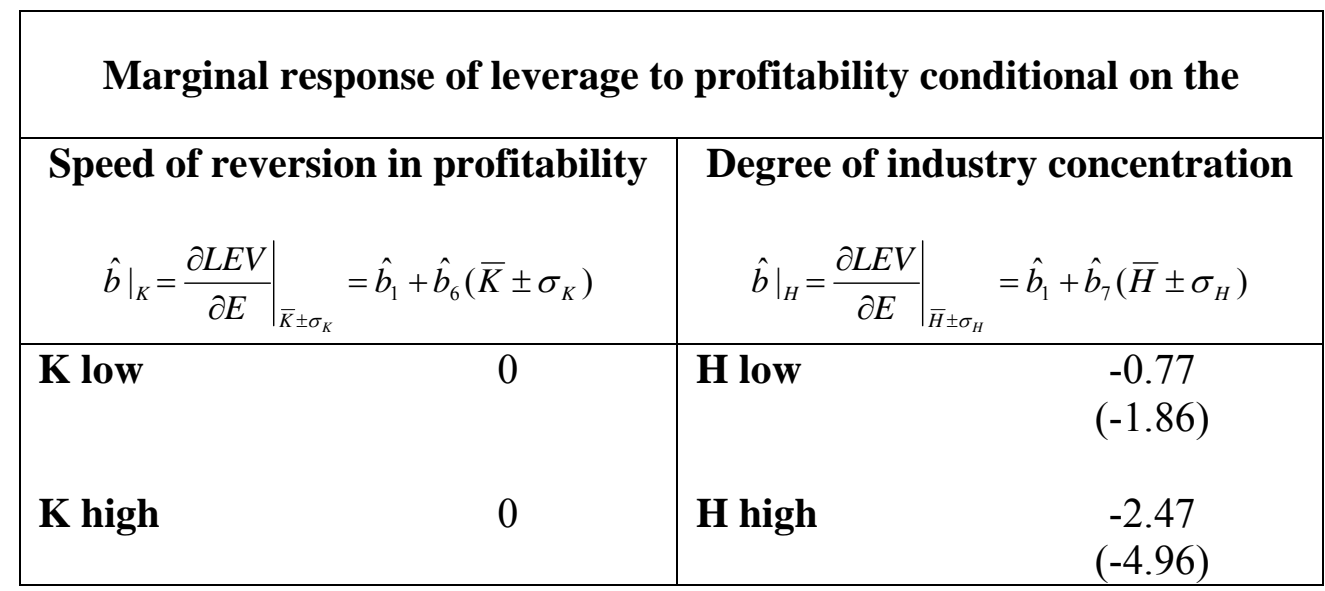

\section{Panel B: Test statistics for differences in conditional coefficients}

T-statistics for the indicated differences in conditional coefficients are presented in the tables below. P-values are in parentheses (onetailed test).

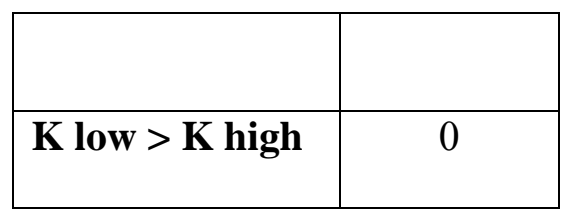

\begin{tabular}{|l|c|}
\hline & \\
\hline H high $>$ H low & $\begin{array}{c}-1.87 \\
(0.0308)\end{array}$ \\
\hline
\end{tabular}




\section{Table 3.11}

\section{Robustness to alternative leverage definitions: regression results}

Annual data are from Compustat from 1982-2000. In the following, LTD/ME is long-term debt (Compustat item 9) scaled by the market value of common equity $\left(25^{*} 199\right)$. LTD/TA is total long-term debt (9) divided by total assets (6). E is EBITDA, or earnings before interest, taxes, depreciation, and amortization (13) scaled by total assets (6). $\mathrm{K}$ is the speed of reversion in EBITDA, THETA is long run mean earnings, and SIGMA is earnings volatility (estimated via the method in Sarkar and Zapatero, 2003), H is the Herfindahl-Hirschman Index calculated annually by SIC from the universe of Compustat firms with positive sales (12), then scaled by 10,000 . EK, EH, and $\mathrm{KH}$ are interaction terms. DEP is depreciation and amortization (125), RD is research and development expense (46). These variables are scaled by total assets (6). SIZE is the natural log of total assets (6), and MTB is the market value of common equity $\left(25^{*} 199\right)$ divided by the book value of common equity $(60)$. Asymptotic standard errors of the estimates are used to calculate t-statistics. The prediction of "n.s." represents not significant.

$$
\begin{gathered}
\mathrm{LEV}_{\mathrm{jt}}=\mathrm{b}_{0}+\mathrm{b}_{1} \mathrm{E}_{\mathrm{jt}}+\mathrm{b}_{2} \mathrm{~K}_{\mathrm{jt}}+\mathrm{b}_{3} \text { THETA }_{\mathrm{jt}}+\mathrm{b}_{4} \mathrm{SIGMA}_{\mathrm{jt}}+\mathrm{b}_{5} \mathrm{H}_{\mathrm{jt}}+\mathrm{b}_{6} \mathrm{EK}_{\mathrm{t}}+\mathrm{b}_{7} \mathrm{EH}_{\mathrm{jt}} \\
+\mathrm{b}_{8} \mathrm{KH}_{\mathrm{jt}}+\mathrm{b}_{9} \mathrm{DEP}_{\mathrm{jt}}+\mathrm{b}_{10} \mathrm{RD}_{\mathrm{jt}}+\mathrm{b}_{11} \mathrm{SIZE}_{\mathrm{jt}}+\mathrm{b}_{12} \mathrm{MTB}_{\mathrm{jt}}+\mathrm{u}_{\mathrm{jt}}
\end{gathered}
$$

\begin{tabular}{lccccc}
\hline & & \multicolumn{4}{c}{ Dependent Variables } \\
\cline { 3 - 6 } & Prediction & \multicolumn{2}{c}{ LTD/ME } & \multicolumn{2}{c}{ LTD/TA } \\
\cline { 3 - 6 } & & Estimate & t & Estimate & t \\
\hline Intercept & & 0.15 & 1.33 & 0.06 & 9.24 \\
E & n.s. & -0.20 & -0.54 & 0.19 & 4.74 \\
K & + & 0.10 & 2.63 & 0.01 & 3.15 \\
THETA & + & -0.40 & -2.79 & 0.03 & 1.61 \\
SIGMA & - & -0.01 & -0.63 & -0.01 & -4.49 \\
H & + & 1.10 & 2.64 & 0.08 & 4.02 \\
EK & - & 0.04 & 1.07 & -0.01 & -1.31 \\
EH & n.s. & -4.78 & -4.14 & -1.33 & -10.33 \\
KH & $?$ & -0.69 & -2.70 & 0.02 & 1.60 \\
DEP & - & 1.43 & 2.03 & 1.00 & 17.43 \\
RD & - & -3.61 & -18.52 & -0.95 & -24.71 \\
SIZE & + & 0.06 & 6.61 & 0.01 & 18.95 \\
MTB & $?$ & -0.04 & -4.77 & 0.00 & -0.53 \\
& & & & & \\
R $^{2}$-adj. & & 0.05 & & 0.13 & \\
\hline
\end{tabular}


Table 3.12

Robustness to alternative leverage definitions: statistical tests

\section{Panel A: Conditional response of leverage to profitability}

The formulas below are used to calculate the marginal responses of leverage to profitability, conditional on the speed of reversion in profitability $(\mathrm{K})$ and industry concentration $(\mathrm{H})$. The conditional marginal responses are based on coefficient estimates from Table 11 and the means and standard deviations of the distributions of K and H. LTD/ME is long-term debt (Compustat item 9) scaled by the market value of common equity (25*199). LTD/TA is long-term debt (9) divided by total assets (6). K is the speed of reversion in EBITDA estimated via the method in Sarkar and Zapatero (2003). K low (high) is the mean of the K distribution minus (plus) one half standard deviation. $\mathrm{H}$ low (high) is the mean of the $\mathrm{H}$ distribution minus (plus) one standard deviation. Asymptotic standard errors of the estimates in Table 11 are used to calculate t-statistics (in parentheses) for each conditional marginal response.

\begin{tabular}{|c|c|c|c|c|c|c|c|}
\hline \multicolumn{8}{|c|}{ Marginal response of leverage to profitability conditional on the } \\
\hline \multicolumn{2}{|c|}{$\left.\hat{b}\right|_{K}=\left.\frac{\partial L E V}{\partial E}\right|_{\bar{K}}$} & $\begin{array}{l}\text { in prof } \\
\hat{b}_{1}+\hat{b}_{6}(\bar{K}\end{array}$ & bility & De & $\begin{array}{l}\text { e of ind } \\
=\left.\frac{\partial L E V}{\partial E}\right|_{\bar{H}}\end{array}$ & $=\hat{b}_{1}+\hat{b}_{7}($ & $\begin{array}{l}\text { ation } \\
\left.F_{H}\right)\end{array}$ \\
\hline \multicolumn{4}{|c|}{ LTD/ME } & \multicolumn{4}{|c|}{ LTD/TA } \\
\hline K low & $\begin{array}{c}0.10 \\
(2.63)\end{array}$ & H low & $\begin{array}{c}-0.39 \\
(-1.22)\end{array}$ & K low & $\begin{array}{c}0.19 \\
(4.74)\end{array}$ & H low & $\begin{array}{c}0.13 \\
(3.69)\end{array}$ \\
\hline K high & $\begin{array}{c}0.10 \\
(2.63)\end{array}$ & H high & $\begin{array}{l}-2.20 \\
(-9.13)\end{array}$ & K high & $\begin{array}{c}0.19 \\
(4.74)\end{array}$ & H high & $\begin{array}{c}-0.37 \\
(-10.06)\end{array}$ \\
\hline
\end{tabular}

Panel B: Test statistics for differences in conditional coefficients

$\mathrm{T}$-statistics for the indicated differences in conditional coefficients are presented in the tables below. P-values are in parentheses (onetailed test).

\begin{tabular}{|l|c|l|c|}
\hline \multicolumn{2}{|c|}{ LTD/ME } & \multicolumn{2}{c|}{ LTD/TA } \\
\hline K low > K high & 0 & K low > K high & 0 \\
\hline H high > H low & $\begin{array}{c}-3.20 \\
(0.0007)\end{array}$ & H high > H low & $\begin{array}{c}-6.94 \\
(<0.0001)\end{array}$ \\
\hline
\end{tabular}




\title{
Table 3.13
}

\section{Robustness to industry concentration definition: regression results for manufacturing firms}

\begin{abstract}
Annual data are from Compustat from 1982-2000. In the following, LEV is long-term debt (Compustat item 9) scaled by the book value of common equity (60). E is EBITDA, or earnings before interest, taxes, depreciation, and amortization (13) scaled by total assets (6). $\mathrm{K}$ is the speed of reversion in EBITDA, THETA is long run mean earnings, and SIGMA is earnings volatility (estimated via the method in Sarkar and Zapatero, 2003), $\mathrm{H}$ is the Herfindahl-Hirschman Index from the U.S. Census Bureau for manufacturing firms, scaled by 10,000. EK, EH, and KH are interaction terms. DEP is depreciation and amortization (125), RD is research and development expense (46). These variables are scaled by total assets (6). SIZE is the natural log of total assets (6), MTB is the market value of common equity $\left(25^{*} 199\right)$ divided by the book value of common equity (60). Asymptotic standard errors of the estimates are used to calculate t-statistics. The prediction of "n.s." represents not significant.
\end{abstract}

$$
\begin{gathered}
\mathrm{LEV}_{\mathrm{jt}}=\mathrm{b}_{0}+\mathrm{b}_{1} \mathrm{E}_{\mathrm{jt}}+\mathrm{b}_{2} \mathrm{~K}_{\mathrm{jt}}+\mathrm{b}_{3} \text { THETA }_{\mathrm{jt}}+\mathrm{b}_{4} \mathrm{SIGMA}_{\mathrm{jt}}+\mathrm{b}_{5} \mathrm{H}_{\mathrm{jt}}+\mathrm{b}_{6} \mathrm{EK}_{\mathrm{t}}+\mathrm{b}_{7} \mathrm{EH}_{\mathrm{jt}} \\
+\mathrm{b}_{8} \mathrm{KH}_{\mathrm{jt}}+\mathrm{b}_{9} \mathrm{DEP}_{\mathrm{jt}}+\mathrm{b}_{10} \mathrm{RD}_{\mathrm{jt}}+\mathrm{b}_{11} \mathrm{SIZE}_{\mathrm{jt}}+\mathrm{b}_{12} \mathrm{MTB}_{\mathrm{jt}}+\mathrm{u}_{\mathrm{jt}}
\end{gathered}
$$

\begin{tabular}{lccc}
\hline & Prediction & Estimate & t \\
\hline Intercept & & 0.60 & 3.15 \\
E & n.s. & -7.63 & -3.60 \\
K & + & -0.28 & -1.67 \\
THETA & + & -0.83 & -3.89 \\
SIGMA & - & 0.00 & 0.16 \\
H & + & 1.99 & 1.88 \\
EK & - & 3.37 & 2.68 \\
EH & n.s. & 4.21 & 0.62 \\
KH & $?$ & -1.61 & -1.94 \\
DEP & - & 4.89 & 3.24 \\
RD & - & -6.84 & -4.54 \\
SIZE & + & 0.02 & 0.66 \\
MTB & $?$ & 0.29 & 2.70 \\
& & & \\
R $^{2}$-adj. & & 0.25 & \\
\hline
\end{tabular}




\section{Table 3.14}

Robustness to industry concentration definition: statistical tests for manufacturing firms

\section{Panel A: Conditional response of leverage to profitability}

The formulas below are used to calculate the marginal responses of leverage to profitability, conditional on the speed of reversion in profitability $(\mathrm{K})$ and industry concentration $(\mathrm{H})$. The conditional marginal responses are based on coefficient estimates from Table 13 and the means and standard deviations of the distributions of $\mathrm{K}$ and $\mathrm{H}$. LEV is defined as the ratio of long term debt to the book value of equity, $\mathrm{K}$ is the speed of reversion in EBITDA estimated via the method in Sarkar and Zapatero (2003). K low (high) is the mean of the $\mathrm{K}$ distribution minus (plus) one half standard deviation. $\mathrm{H}$ low (high) is the mean of the $\mathrm{H}$ distribution minus (plus) one standard deviation. Asymptotic standard errors of the estimates in Table 13 are used to calculate t-statistics (in parentheses) for each conditional marginal response.

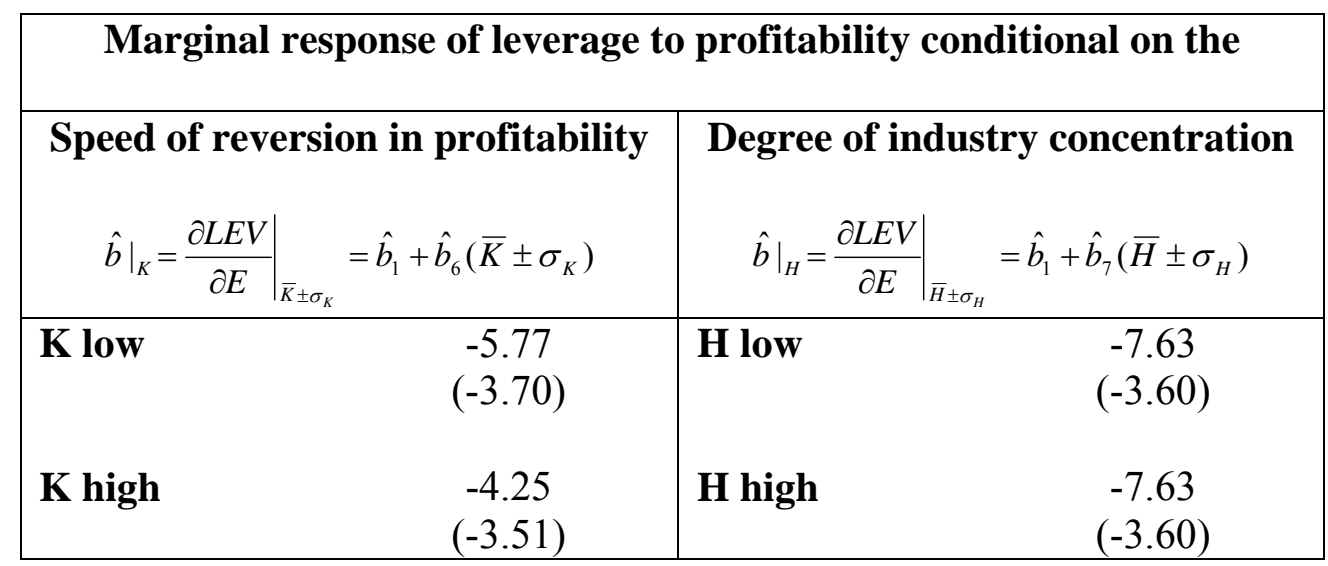

\section{Panel B: Test statistics for differences in conditional coefficients}

$\mathrm{T}$-statistics for the indicated differences in conditional coefficients are presented in the tables below. P-values are in parentheses (onetailed test).

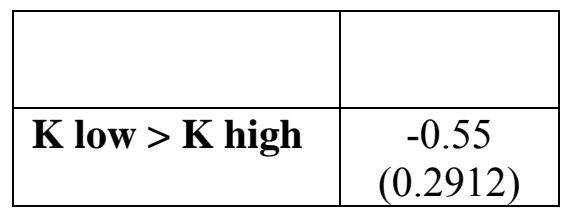

\begin{tabular}{|l|l|}
\hline & \\
\hline H high > H low & 0 \\
\hline
\end{tabular}

